Keywords: Saltstone

Regulatory, Classification

TCLP

Retention: Permanent

\title{
Saltstone Vault Classification Samples Modular Caustic Side Solvent Extraction Unit/Actinide Removal Process Waste Stream April 2011
}

R. E. Eibling

September 2011

Savannah River National Laboratory

Savannah River Nuclear Solutions, LLC

Aiken, SC 29808

Prepared for the U.S. Department of Energy under contract number DE-AC09-08SR22470. 
SRNL-STI-2011-00561

Revision 0

\section{DISCLAIMER}

This work was prepared under an agreement with and funded by the U.S. Government. Neither the U.S. Government or its employees, nor any of its contractors, subcontractors or their employees, makes any express or implied:

1. warranty or assumes any legal liability for the accuracy, completeness, or for the use or results of such use of any information, product, or process disclosed; or

2. representation that such use or results of such use would not infringe privately owned rights; or

3. endorsement or recommendation of any specifically identified commercial product, process, or service.

Any views and opinions of authors expressed in this work do not necessarily state or reflect those of the United States Government, or its contractors, or subcontractors.

\section{Printed in the United States of America}

Prepared for

U.S. Department of Energy 


\section{REVIEWS AND APPROVALS}

AUTHORS:

R. E. Eibling, Process Engineering Development

Date

TECHNICAL REVIEW:

M. M. Reigel, Process Engineering Development

Date

APPROVAL:

A. B. Barnes, Manager

Date

Process Engineering Development

S. L. Marra, Manager

Date

Environmental \& Chemical Process Technology Research Programs

J. E. Occhipinti, Manager

Date

Waste Solidification Engineering 


\section{EXECUTIVE SUMMARY}

Savannah River National Laboratory (SRNL) was asked to prepare saltstone from samples of Tank 50H obtained by SRNL on April 5, 2011 (Tank 50H sampling occurred on April 4, 2011) during 2QCY11 to determine the non-hazardous nature of the grout and for additional vault classification analyses. The samples were cured and shipped to Babcock \& Wilcox Technical Services Group-Radioisotope and Analytical Chemistry Laboratory (B\&W TSG-RACL) to perform the Toxic Characteristic Leaching Procedure (TCLP) ${ }^{(1)}$ and subsequent extract analysis on saltstone samples for the analytes required for the quarterly analysis saltstone sample. In addition to the eight toxic metals - arsenic, barium, cadmium, chromium, mercury, lead, selenium and silver - analytes included the underlying hazardous constituents (UHC) antimony, beryllium, nickel, and thallium which could not be eliminated from analysis by process knowledge. Additional inorganic species determined by B\&W TSG-RACL include aluminum, boron, chloride, cobalt, copper, fluoride, iron, lithium, manganese, molybdenum, nitrate/nitrite as Nitrogen, strontium, sulfate, uranium, and zinc and the following radionuclides: gross alpha, gross beta/gamma, ${ }^{3} \mathrm{H},{ }^{60} \mathrm{Co},{ }^{90} \mathrm{Sr},{ }^{99} \mathrm{Tc},{ }^{106} \mathrm{Ru},{ }^{106} \mathrm{Rh},{ }^{125} \mathrm{Sb},{ }^{137} \mathrm{Cs},{ }^{137 \mathrm{~m}} \mathrm{Ba},{ }^{154} \mathrm{Eu},{ }^{238} \mathrm{Pu},{ }^{239 / 240} \mathrm{Pu}$, ${ }^{241} \mathrm{Pu},{ }^{241} \mathrm{Am},{ }^{242} \mathrm{Cm}$, and ${ }^{243 / 244} \mathrm{Cm}$. B\&W TSG-RACL provided subsamples to GEL Laboratories, LLC for analysis for the VOCs benzene, toluene, and 1-butanol. GEL also determines phenol (total) and the following radionuclides: ${ }^{147} \mathrm{Pm},{ }^{226} \mathrm{Ra}$ and ${ }^{228} \mathrm{Ra}$.

Preparation of the 2QCY11 saltstone samples for the quarterly analysis and for vault classification purposes and the subsequent TCLP analyses of these samples showed that:

- The saltstone waste form disposed of in the Saltstone Disposal Facility in 2QCY11 was not characteristically hazardous for toxicity.

- The concentrations of the eight RCRA metals and UHCs identified as possible in the saltstone waste form were present at levels below the UTS.

- Most of the inorganic species measured in the leachate do not exceed the MCL, SMCL or TW limits.

- The inorganic waste species that exceeded the MCL by more than a factor of 10 were nitrate, nitrite and the sum of nitrate and nitrite.

- Analyses met all quality assurance specifications of US EPA SW-846.

- The organic species (benzene, toluene, 1-butanol, phenol) were either not detected or were less than reportable for the vault classification samples.

- The gross alpha and radium isotopes could not be determined to the MCL because of the elevated background which raised the detection limits.

- Most of the beta/gamma activity was from ${ }^{137} \mathrm{Cs}$ and its daughter ${ }^{137 \mathrm{~m}} \mathrm{Ba}$.

- The concentration of ${ }^{137} \mathrm{Cs}$ and ${ }^{90} \mathrm{Sr}$ were present in the leachate at concentrations $1 / 40^{\text {th }}$ and $1 / 8^{\text {th }}$ respectively than in the 2003 vault classification samples.

The saltstone waste form placed in the Saltstone Disposal Facility in 2QCY11 met the SCHWMR R.61-79.261.24(b) RCRA metals requirements for a nonhazardous waste form. The TCLP leachate concentrations for nitrate, nitrite and the sum of nitrate and nitrite were greater than $10 \mathrm{x}$ the MCLs in SCDHEC Regulations R.61-107.19, Part I A, which confirms the Saltstone Disposal Facility classification as a Class 3 Landfill. The saltstone waste form placed in the Saltstone Disposal Facility in 2QCY11 met the R.61-79.268.48(a) non wastewater treatment standards. 


\section{TABLE OF CONTENTS}

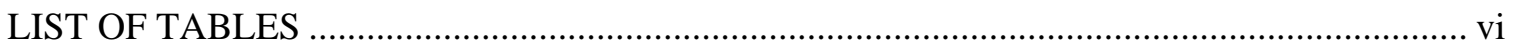

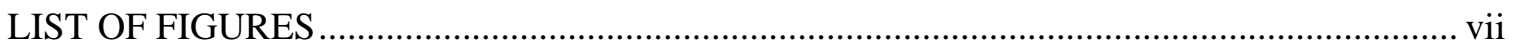

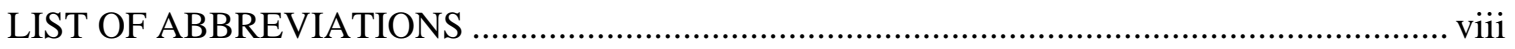

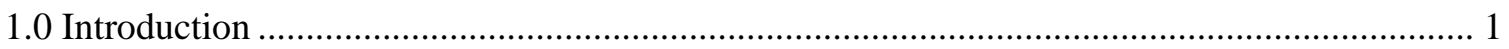

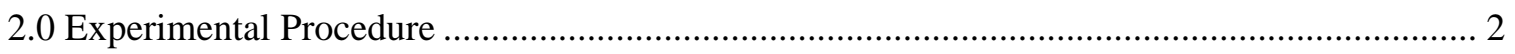

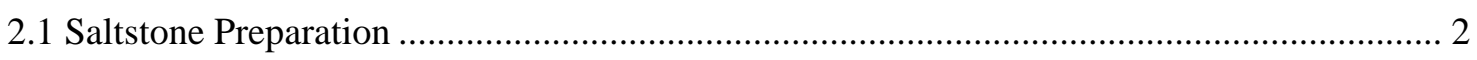

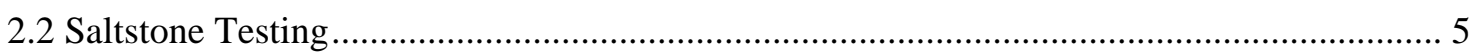

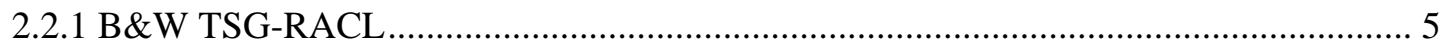

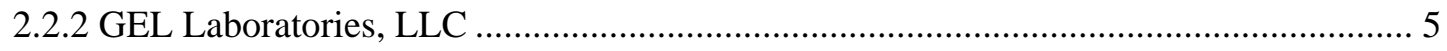

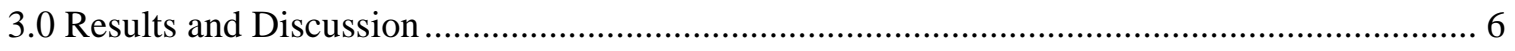

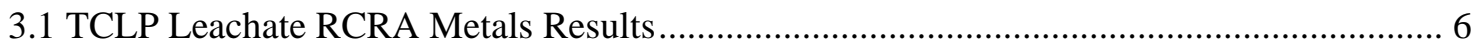

3.2 TCLP Leachate Results for Other Inorganic Species ......................................................... 7

3.3 TCLP Leachate Results for Benzene, Toluene, 1-Butanol and Phenol ............................... 9

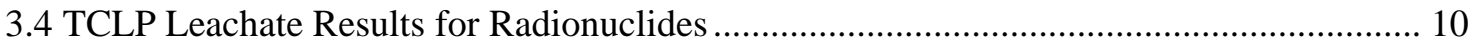

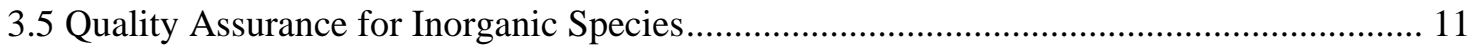

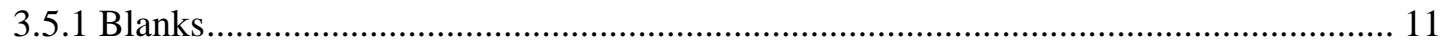

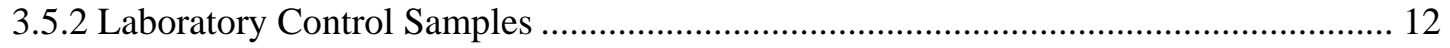

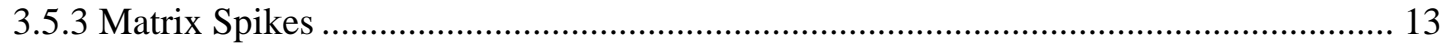

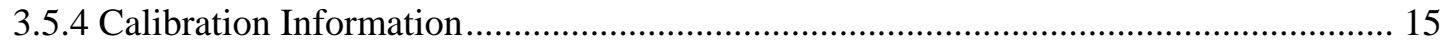

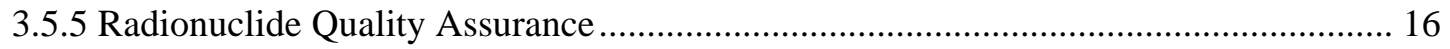

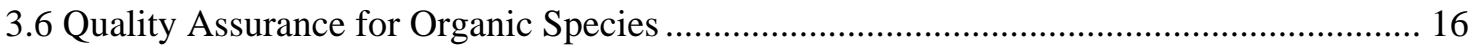

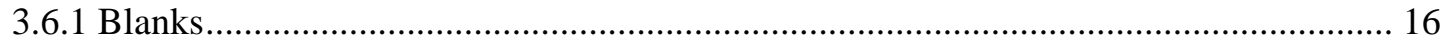

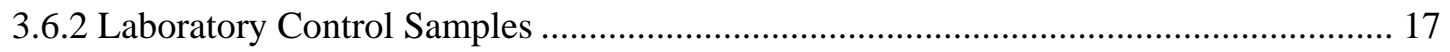

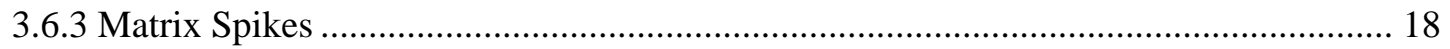

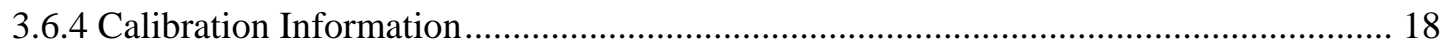

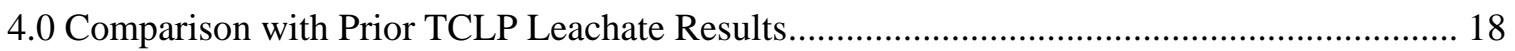

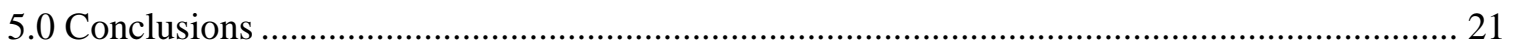

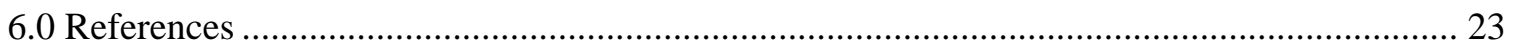

Appendix South Carolina Department of Health and Environmental Control Forms................. 24 


\section{LIST OF TABLES}

Table 2-1. Sample Results of TCLP Metals from 2Q11 Tank 50H WAC Analysis. 3

Table 2-2 Customer Recommended Values for Preparation of 2Q11 TCLP and Vault

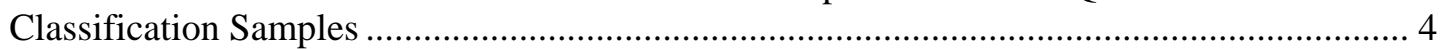

Table 3-1 TCLP Leachates RCRA Metal Results and Limits ..................................................... 6

Table 3-2 TCLP Leachate Results for Other Inorganic Species of Interest .................................. 8

Table 3-3 Total Anion Results Based on Water Leach of Saltstone Vault Classification Samples 9

Table 3-4 TCLP Leachate Results for Organic Species of Interest ............................................. 10

Table 3-5 Radionuclide Results for the TCLP Leachate ............................................................ 10

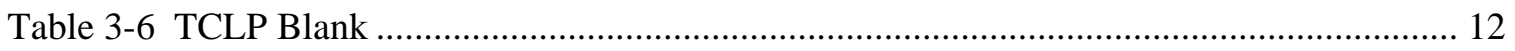

Table 3-7 Laboratory Control Sample for Inorganics ............................................................... 13

Table 3-8 TCLP Leachates Matrix Spike and Duplicate Results ................................................ 14

Table 3-9 Matrix Spike and Duplicate Results for Other Metals of Interest................................ 14

Table 3-10 Matrix Spike and Spike Duplicate Results for Anions …......................................... 15

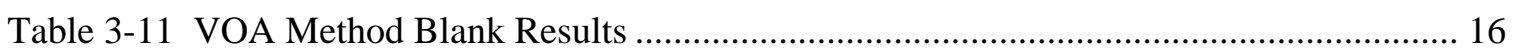

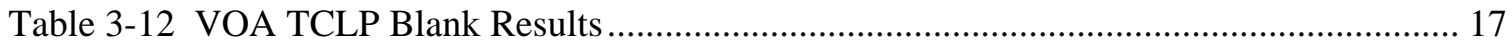

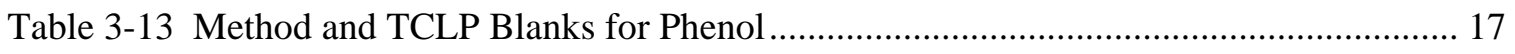

Table 3-14 VOA and Phenol Laboratory Control Samples....................................................... 17

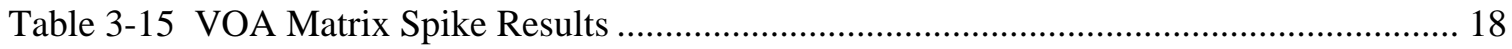

Table 4-1 Comparison of Current 2011 RCRA TCLP Results with Past Results ......................... 19

Table 4-2 Comparison of Current Other Metals TCLP Results with Past Results...................... 20

Table 4-3 Comparison of Current Radionuclide TCLP Results with Past Results ...................... 20 
SRNL-STI-2011-00561

Revision 0

\section{LIST OF FIGURES}

Figure 2-1 Flowchart of Saltstone Preparation and Analysis ...................................................... 2

Figure 2-2 Data sheet for the Saltstone mix used to prepare the 2Q11 Vault Classification

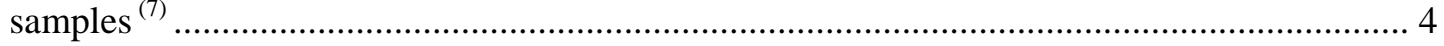




\section{LIST OF ABBREVIATIONS}

\begin{tabular}{|c|c|}
\hline ARP & Actinide Removal Process \\
\hline $\begin{array}{l}\text { B\&W TSG- } \\
\text { RACL }\end{array}$ & $\begin{array}{l}\text { B \& W Technical Services Group-Radioisotope and Analytical } \\
\text { Chemistry Laboratory }\end{array}$ \\
\hline CVAA & Cold Vapor Atomic Absorption \\
\hline DDA & Deliquification, Dissolution, and Adjustment \\
\hline DL & Detection Limit \\
\hline DSS-HT & Decontaminated Salt Solution Hold Tank \\
\hline ESS-WP & Environmental Services Section - Waste Programs \\
\hline ETP & Effluent Treatment Project \\
\hline IC & Ion Chromatography \\
\hline ICP-MS & Inductively Coupled Plasma - Mass Spectrometer \\
\hline ISWLF & Industrial Solid Waste Landfill \\
\hline IWTF & Industrial Wastewater Treatment Facility \\
\hline LCS & Laboratory Control Sample \\
\hline MCL & Maximum Contaminant Level \\
\hline $\mathrm{MCU}$ & Modular Caustic Side Solvent Extraction Unit \\
\hline MS & Matrix Spike \\
\hline MSD & Matrix Spike Duplicate \\
\hline QL & Quantitation Limit \\
\hline RCRA & Resource Conservation and Recovery Act \\
\hline RER & Replicate Error Ratio \\
\hline RL & Reporting Limit \\
\hline RPD & Relative Percent Differences \\
\hline SAP & Sampling and Analysis Plan \\
\hline SCDHEC & South Carolina Department of Health and Environmental Control \\
\hline SCHWMR & South Carolina Hazardous Waste Management Regulations \\
\hline SDF & Saltstone Disposal Facility \\
\hline SDG & Sample Delivery Group \\
\hline SMCL & Secondary Maximum Contaminant Level \\
\hline SPF & Saltstone Production Facility \\
\hline SRNL & Savannah River National Laboratory \\
\hline SWLF & Z-Area Solid Waste Landfill \\
\hline TCLP & Toxic Characteristic Leaching Procedure \\
\hline UHC & Underlying Hazardous Constituent \\
\hline
\end{tabular}


SRNL-STI-2011-00561

Revision 0

UTS Universal Treatment Standards 


\subsection{Introduction}

The Saltstone Production Facility (SPF) receives waste from Tank $50 \mathrm{H}$ for treatment. Tank 50H contains waste streams (i.e. H-Canyon low-activity waste ${ }^{(2)}$, Effluent Treatment Project (ETP) waste $^{(3)}$, and decontaminated salt solution from the Actinide Removal Process / Modular Caustic Side Solvent Extraction Unit (ARP/MCU)) which is processed for disposal in the Saltstone Disposal Facility (SDF). The Sampling and Analysis Plan (SAP) ${ }^{(4)}$ provides the South Carolina Department of Health and Environmental Control (SCDHEC) with the chemical and physical characterization strategy for the salt solution which is to be disposed of in the Z-Area Solid Waste Landfill (SWLF), during Interim Salt Processing. During operation, the salt waste stream will be sampled quarterly and grout samples prepared to determine the non-hazardous nature of the grout to meet the requirements of the SCDHEC regulation for the "Characteristic of Toxicity", R.6179.261.24(b) and the "Universal Treatment Standards”, R.61-79.268.48. ${ }^{(5)}$

The SAP also specifies that additional sampling will be conducted as new waste streams are identified for treatment and disposal at the Saltstone Industrial Wastewater Treatment Facility (IWTF) and SWLF or every five years in accordance with SCDHEC Regulation R.61-107.19. ${ }^{(4)}$ In the second quarter of calendar year 2011, additional material was collected from Tank $50 \mathrm{H}$ in order to support the additional analyses that are required due to the completion of the Deliquification, Dissolution, and Adjustment (DDA) waste stream. This is a change in the waste stream composition and the analysis of this vault classification sample satisfies the requirements described in the SAP.

In the second quarter of the 2011 calendar year (2QCY11), Tank 50H accepted transfers of approximately $15 \mathrm{kgal}$ from the Effluent Treatment Project (ETP), approximately 2 kgal from Tank 710-the H-Canyon General Purpose Evaporator, approximately 63 kgal from the $\mathrm{H}$ Canyon Super Kukla campaign, approximately $370 \mathrm{kgal}$ from the Actinide Removal Process / Modular Caustic Side Solvent Extraction Unit (ARP/MCU) Decontaminated Salt Solution Hold Tank (DSS-HT), and approximately $10 \mathrm{kgal}$ from other sources.

Savannah River National Laboratory (SRNL) was asked to prepare saltstone from samples of Tank 50H obtained April 5, 2011 during 2QCY11 to determine the non-hazardous nature of the grout and for additional vault classification analyses. The samples were cured and shipped to Babcock \& Wilcox Technical Services Group-Radioisotope and Analytical Chemistry Laboratory (B\&W TSG-RACL) to perform the Toxic Characteristic Leaching Procedure (TCLP) ${ }^{(1)}$ and subsequent extract analysis on saltstone samples for the analytes required for the quarterly analysis saltstone sample. In addition to the eight toxic metals-arsenic, barium, cadmium, chromium, mercury, lead, selenium and silver-analytes included the underlying hazardous constituents (UHC) antimony, beryllium, nickel, and thallium which could not be eliminated from analysis by process knowledge. Additional inorganic species determined by B\&W TSG-RACL include aluminum, boron, chloride, cobalt, copper, fluoride, iron, lithium, manganese, molybdenum, nitrate/nitrite as Nitrogen, strontium, sulfate, uranium, and zinc and the following radionuclides: gross alpha, gross beta/gamma, ${ }^{3} \mathrm{H},{ }^{60} \mathrm{Co},{ }^{90} \mathrm{Sr},{ }^{99} \mathrm{Tc},{ }^{106} \mathrm{Ru},{ }^{106} \mathrm{Rh},{ }^{125} \mathrm{Sb},{ }^{137} \mathrm{Cs}$, ${ }^{137 \mathrm{~m}} \mathrm{Ba},{ }^{154} \mathrm{Eu},{ }^{238} \mathrm{Pu},{ }^{239 / 240} \mathrm{Pu},{ }^{241} \mathrm{Pu},{ }^{241} \mathrm{Am},{ }^{242} \mathrm{Cm}$, and ${ }^{243 / 244} \mathrm{Cm}$. B\&W TSG-RACL provided subsamples to GEL Laboratories, LLC for analysis for the VOCs benzene, toluene, and 1-butanol. GEL also determines phenol (total) and the following radionuclides: ${ }^{147} \mathrm{Pm},{ }^{226} \mathrm{Ra}$ and ${ }^{228} \mathrm{Ra}$. 


\subsection{Experimental Procedure}

This section is a summary of the approach taken to prepare and characterize the saltstone samples. The saltstone sample preparation was performed at SRNL. Saltstone sample characterization was performed at both B\&W TSG-RACL facility in Lynchburg, Virginia and the GEL laboratory facility in Charleston, South Carolina. Figure 2-1 is a flowchart of the steps taken to prepare and characterize the saltstone samples.

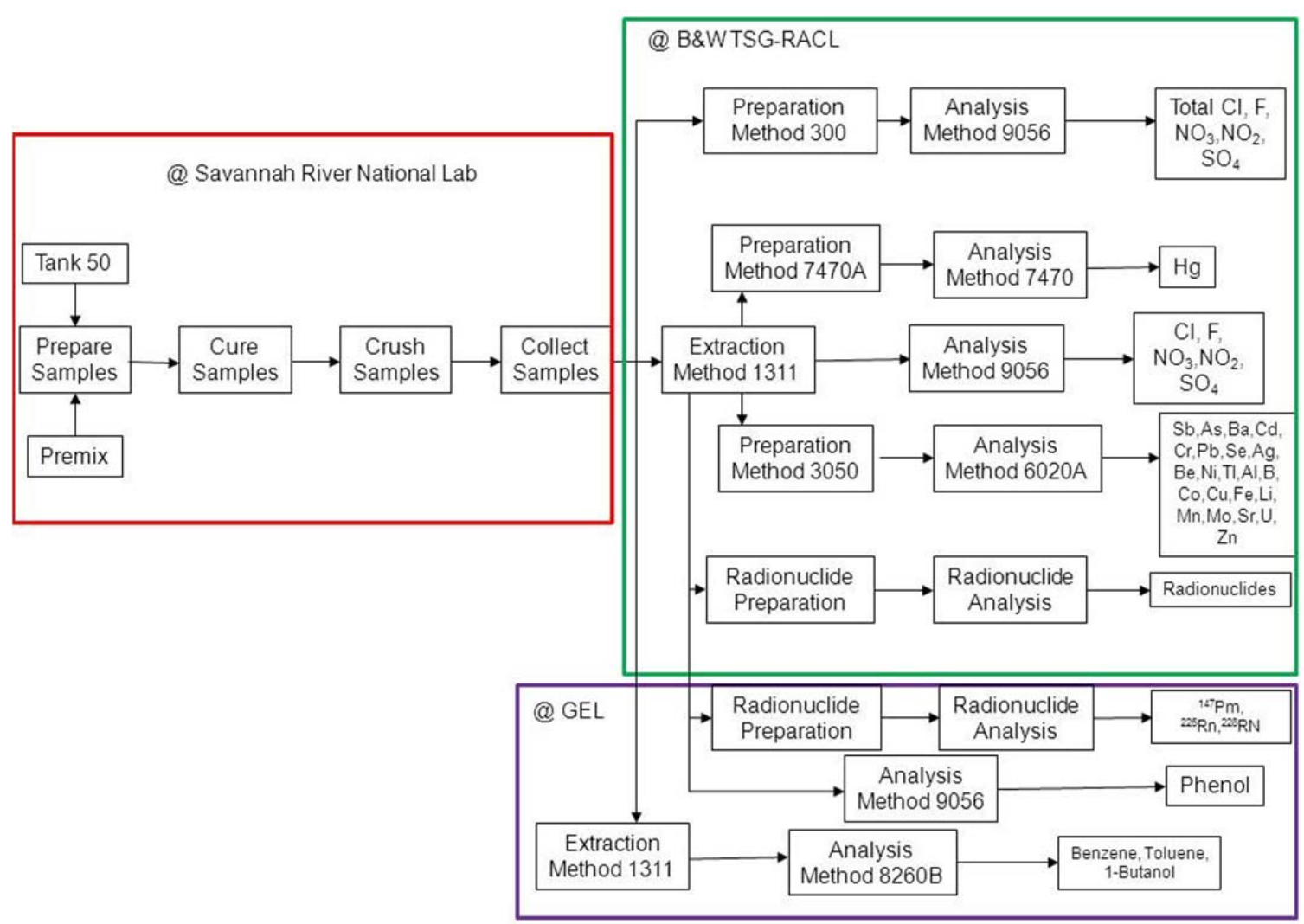

Figure 2-1 Flowchart of Saltstone Preparation and Analysis

\subsection{Saltstone Preparation}

Saltstone preparation was performed at SRNL. The weight percent solids data used for vault classification samples were taken from the quarterly Waste Acceptance Criteria (WAC) analyses performed on Tank 50H. ${ }^{(6)}$ Table 2-1 lists the concentration of TCLP metals and other species of interest in the salt solution from the WAC analysis ${ }^{(6)}$ for the samples. As shown in Table 2-1, the contents of Tank $50 \mathrm{H}$ exceed the regulatory limits for chromium, mercury, and possibly phenol, and therefore must be treated and disposed of in a non-hazardous waste form. Table 2-2 contains the parameters used to prepare the vault classification samples. ${ }^{(7)}$

Saltstone samples for vault classification were prepared with the Tank $50 \mathrm{H}$ blended salt solution and a premix of cement, slag, and fly ash. Figure 2-2 shows the formulation used to prepare these samples. The salt solution, admixtures and premix materials were combined in a blender and mixed at low speed for one minute, inspected for incorporation of the premix, and then mixed at high speed for an additional two minutes. After the saltstone slurry was mixed, it was cast into a 
polyethylene zip top bag. The bag was laid flat and the air was expelled prior to sealing. The sample was cured flat in a polyethylene bag to facilitate the size reduction step needed to conform to the particle size requirements of the TCLP method.

After curing for not less than 28 days ${ }^{1}$ — 28 days for the $2 \mathrm{Q} 11$ sample, the saltstone was removed from the container and a portion of the saltstone was crushed to particles less than 0.9 centimeters (3/8 inch) as prescribed by Section 7.13 of the TCLP method. ${ }^{(1)}$ The crushed saltstone was packaged into containers provided by Environmental Services Section - Waste Programs (ESSWP). After the saltstone has been crushed, sieved and packaged, the sample is deemed "collected." (4) ESS-WP retrieved the samples from SRNL and transported them to B\&W TSGRACL for extraction and analysis. B\&W TSG-RACL repackaged a portion of the sample and shipped the sample to GEL Laboratories to perform analysis for the organic species (benzene, toluene, 1-butanol, phenol) and for the radionuclides ( ${ }^{147}$ Promethium, ${ }^{226}$ Radium and ${ }^{228}$ Radium).

Table 2-1. Sample Results of TCLP Metals from 2Q11 Tank 50H WAC Analysis

\begin{tabular}{|c||c|c||}
\hline- & $\begin{array}{c}\text { Sample Results } \\
(\mathbf{m g} / \mathbf{L})(6)\end{array}$ & $\begin{array}{c}\text { Regulatory Limits } \\
(\mathbf{m g} / \mathbf{L})\end{array}$ \\
\hline- & $\mathbf{2 Q 1 1}$ & Toxicity $^{\mathbf{a}}$ \\
\hline $\mathbf{A s}$ & $<0.104$ & 5 \\
\hline $\mathbf{B a}$ & $<0.49$ & 100 \\
\hline $\mathbf{C d}$ & $<0.66$ & 1 \\
\hline $\mathbf{C r}$ & 45.5 & 5 \\
\hline $\mathbf{P b}$ & 0.127 & 5 \\
\hline $\mathbf{H g}$ & 18.8 & 0.2 \\
\hline $\mathbf{S e}$ & $<0.416$ & 1 \\
\hline $\mathbf{A g}$ & $<1.37$ & 5 \\
\hline-- & -- & $\mathbf{U H C}$ \\
\hline $\mathbf{S b}$ & $<1.01$ & 1.15 \\
\hline $\mathbf{B e}$ & $<0.076$ & 1.22 \\
\hline $\mathbf{N i}$ & 6.03 & 11 \\
\hline $\mathbf{T l}$ & $<0.037$ & 0.20 \\
\hline- & - & $\mathbf{( m g} / \mathbf{k g})$ \\
\hline benzene & $<0.150$ & 10 \\
\hline phenol & $<10.0$ & 6.2 \\
\hline
\end{tabular}

NM - Not Measured

a SCHWMR R.61-79.261.24(b) “Characteristic of Toxicity.”

b SCHWMR R.61-79.268.48 "Universal Treatment Standards.”

\footnotetext{
${ }^{1}$ Samples are considered ready for analysis after 28 days. Samples are not crushed until shipment has been scheduled.
} 
Table 2-2 Customer Recommended Values for Preparation of 2Q11 TCLP and Vault Classification Samples

\begin{tabular}{|c||c|}
\hline Parameter & $\mathbf{2 Q 1 1}$ \\
\hline Water-to-Premix ratio & 0.60 \\
\hline $\begin{array}{c}\text { (Daratard 17) gal/Ton premix } \\
\text { premix }\end{array}$ & 0.00 \\
\hline \multicolumn{2}{|c|}{ (Dow Corning Q2-3183A) gal/Ton } \\
\hline
\end{tabular}

Saltstone Mix Data Sheet

\begin{tabular}{|c|c|c|c|}
\hline \multicolumn{2}{|l|}{ MIX \# 0124} & \multicolumn{2}{|c|}{ Date: $\quad 4 / 25 / 2011$} \\
\hline Material & $\%$ & WT\% & Grams \\
\hline Waste Solution: Tank 50 4/5/11 2Q11 & & \multirow{3}{*}{44.22} & \multirow{3}{*}{230.00} \\
\hline \multirow{2}{*}{$\begin{array}{l}\text { Wt\% Solids \# } \frac{24.80}{172.96} \\
\text { Grams Water }\end{array}$} & & & \\
\hline & & & \\
\hline Admixture: $\quad \underline{Q} 2$ Antifoam $^{\star}$ & & 0.03 & 0.08 \\
\hline \multicolumn{4}{|l|}{ Admixture: } \\
\hline \multicolumn{4}{|l|}{ Admixture: } \\
\hline Premix & & 55.76 & 290.00 \\
\hline Cement ( $\%$ of Premix) & 10 & 5.58 & 29.00 \\
\hline Slag ( $\%$ of Premix) & 45 & 25.09 & 130.50 \\
\hline Fly Ash ( $\%$ of Premix) & 45 & 25.09 & 130.50 \\
\hline Total & 100 & 100.01 & 520.08 \\
\hline Water to Premix Ratio & \multicolumn{2}{|c|}{0.60} & \\
\hline \multicolumn{4}{|l|}{$\begin{array}{l}\text { Calculations: } \\
\text { Use CBO fly ash }\end{array}$} \\
\hline \multicolumn{4}{|l|}{ From customer: $0.60 \mathrm{w} / \mathrm{p}, 0.10 \mathrm{gpm}, 33 \mathrm{~T} / \mathrm{hr}$ dry feed } \\
\hline \multicolumn{4}{|c|}{ Q2 is diluted Q2 amount . In plant, diluted 1:4 in water. } \\
\hline \multicolumn{4}{|c|}{$\begin{array}{l}\text { * Actual amount of Q2 added to sample is } 0.078 \mathrm{~g} \text {. Q2 was diluted to a } 1: 4 \text { in water and } 100 \mathrm{uL} \\
\text { pipette was used to add the diluted Q2 to the sample. }\end{array}$} \\
\hline \multicolumn{4}{|c|}{ Part of this sample will also be used for the Vault Classification Sample testing. } \\
\hline
\end{tabular}

Figure 2-2 Data sheet for the Saltstone mix used to prepare the 2Q11 Vault Classification samples ${ }^{(7)}$ 
SRNL-STI-2011-00561

Revision 0

\subsection{Saltstone Testing}

Saltstone testing was performed by B\&W TSG-RACL and GEL Laboratories, LLC. Activities associated with the 2QCY11 saltstone vault classification samples were:

\section{At B\&W TSG-RACL,}

- performing the TCLP extraction,

- digesting the TCLP leachate, and

- analyzing the digested leachate.

At GEL

- performing extractions on solid subsamples shipped from B\&W TSG-RACL and

- analyzing extracts.

\subsubsection{B\&W TSG-RACL}

The TCLP sample arrived at B\&W TSG-RACL, Lynchburg, Virginia on May 26, 2011 for analysis. The three Vault classification samples arrived at B\&W TSG-RACL, Lynchburg, Virginia on June 9, 2011 for analysis. Shipping container temperatures were documented to be within specifications for the TCLP sample. The shipping container for the three Vault classification samplers arrived 17 days after the "collected" date and the container temperature was $15{ }^{\circ} \mathrm{C}$. The samples were delivered with proper chain of custody documentation and signatures. All sample containers arrived without any visible signs of tampering or breakage.

The Metals method 6020A analysis was performed on an X-7 Series Inductively Coupled Plasma - Mass Spectrometer (ICP-MS). The instrument measures ions produced by a radio-frequency inductively coupled plasma. Analyte species originating in a liquid are nebulized and the resulting aerosol transported by argon gas into the plasma torch. The ions produced by high temperatures are entrained in the plasma gas and introduced, by means of an interface, into a mass spectrometer. The ions produced in the plasma are sorted according to their mass-to-charge ratios and quantified with a channel electron multiplier. Mass interferences must be assessed and valid corrections applied or the data flagged to indicate problems.

The Metals method 7470A analysis was performed on a Leman PC 200 II instrument which consists of a cold vapor atomic absorption spectrometer (CVAA) set to detect mercury at a wavelength of $253.7 \mathrm{~nm}$. The mercury is reduced to the elemental state and aerated from solution in a closed system. The mercury vapor passes through a cell positioned in the light path of an atomic absorption spectrophotometer. Absorbance (peak height) is measured as a function of mercury concentration.

The Anion method 9066 analysis was performed on a Dionex DX-100 ion chromatograph (IC). The radionuclides were measured using Alpha Spectroscopy, Gamma Spectroscopy, and Beta Liquid Scintillation.

A portion of the leachate from the second quarter TCLP sample and from one of the Vault Classification samples were used as the quality control samples (matrix spike) for the ICP-MS, CVAA and IC.

\subsubsection{GEL Laboratories, LLC}

The subsamples arrived at GEL Laboratories, LLC, Charleston, South Carolina on August 18, 2011 for analysis. Shipping container temperatures were documented to be within specifications. All sample containers arrived without any visible signs of tampering or breakage. The sample 
arrived with the proper chain of custody documentation and signatures. The Volatile Organics Analysis (VOA) method (8260B) analysis was performed with an HP6890/HP5973 gas chromatograph/mass spectrometer using a J\&W DB-624 column. Method 9066 was performed using a Lachat QuickChem FIA+ 8000 Series. Radionuclide measurements were performed by Gamma Spectroscopy and Beta Liquid Scintillation.

\subsection{Results and Discussion}

Results summarized in the following tables are from the data package for these analyses. ${ }^{(8)}$ Data is presented in these results as reported by the vendors.

\subsection{TCLP Leachate RCRA Metals Results}

The results for the RCRA metals from the TCLP leachate performed at B\&W TSG-RACL are shown in Table 3-1. Analytes detected but at concentrations too low to determine quantitatively have been flagged with the "B" qualifier. Analytes that were not detected have been listed as less than quantities. In addition to the results, Detection Limits (DLs) have been given. The DL is the minimum concentration of an analyte that can be identified, measured, and reported with 99\% confidence that the concentration is above zero. The DL values given in the table are the results from this study adjusted for sample dilution. The Quantitation Limit (QL) is the lowest level at which an analyte may be accurately and reproducibly achieved.

Table 3-1 TCLP Leachates RCRA Metal Results and Limits

\begin{tabular}{|c|c|c|c|c|c|c|}
\hline- & $\begin{array}{l}\text { Sample } \\
\text { Results }\end{array}$ & \multicolumn{2}{|c|}{ Analytical Limits } & \multicolumn{3}{|c|}{ Regulatory Limits } \\
\hline $\begin{array}{l}\text { SRS } \\
\text { ID }\end{array}$ & 2Q11 & $\begin{array}{c}\text { Detection } \\
\text { Limit }\end{array}$ & $\begin{array}{c}\text { Quantitation } \\
\text { Limit }\end{array}$ & MCL $^{c}$ & UTS $^{\mathbf{b}}$ & Toxicity $^{\mathrm{a}}$ \\
\hline $\begin{array}{c}\text { B\&W } \\
\text { ID }\end{array}$ & $\begin{array}{l}\text { 1105017- } \\
01 \mathrm{~A}\end{array}$ & $(\mathrm{mg} / \mathrm{L})$ & $(\mathrm{mg} / \mathrm{L})$ & $(\mathrm{mg} / \mathrm{L})$ & $\begin{array}{c}\text { Nonwastewater } \\
\text { Standard } \\
\text { (mg/L TCLP) }\end{array}$ & $(\mathrm{mg} / \mathrm{L})$ \\
\hline As & $1.34 \mathrm{E}-02$ & $1.00 \mathrm{E}-04$ & 5.56E-03 & 0.01 & 5 & 5 \\
\hline $\mathbf{B a}$ & 2.34E-01 & 4.40E-04 & 5.56E-02 & 2 & 21 & 100 \\
\hline Cd & ${ }^{B} 3.2 E-04$ & $1.10 \mathrm{E}-04$ & 5.56E-03 & 0.005 & 0.11 & 1 \\
\hline $\mathrm{Cr}$ & 1.83E-02 & $3.60 \mathrm{E}-04$ & 1.11E-02 & 0.1 & 0.6 & 5 \\
\hline $\mathbf{P b}$ & ${ }^{B} 2.7 \mathrm{E}-03$ & 4.80E-04 & 5.56E-03 & $0.015^{\mathrm{d}}$ & 0.75 & 5 \\
\hline Hg & $1.86 \mathrm{E}-02$ & 7.00E-05 & 2.00E-04 & 0.002 & 0.025 & 0.2 \\
\hline Se & $\mathrm{E}_{1.59 \mathrm{E}-01}$ & 2.40E-04 & 2.78E-02 & 0.05 & 5.7 & 1 \\
\hline Ag & ${ }^{B} 1.4 \mathrm{E}-04$ & $6.00 \mathrm{E}-05$ & $5.56 \mathrm{E}-03$ & $0.1^{\mathrm{e}}$ & 0.14 & 5 \\
\hline Sb & ${ }^{B} 3.0 \mathrm{E}-03$ & 1.30E-04 & 1.11E-02 & 0.006 & 1.15 & - \\
\hline Be & $<1.6 \mathrm{E}-04$ & 1.60E-04 & 5.56E-03 & 0.004 & 1.22 & - \\
\hline $\mathbf{N i}$ & ${ }^{B} 3.5 E-03$ & $1.58 \mathrm{E}-03$ & 5.56E-03 & - & 11 & - \\
\hline TI & ${ }^{\mathrm{B}} 2.6 \mathrm{E}-04$ & 2.10E-04 & 5.56E-03 & 0.002 & 0.2 & - \\
\hline
\end{tabular}

- Indicates a location in the table for which an entry would not be appropriate.

B Analyte is present at a concentration above the DL but less than the QL.

${ }^{\mathrm{E}}$ Associated Serial Dilution is outside percent difference quality control criteria.

a R.61-79.261.24(b) "Characteristic of Toxicity."

${ }^{\mathrm{b}}$ R.61-79.268.48 "Universal Treatment Standards.” 
${ }^{c}$ SCDHEC State Primary Drinking Water Regulation Maximum Contaminant Levels.

${ }^{\mathrm{d}}$ Lead action level from SCDHEC 61-58.11.B.

e Secondary drinking water parameter.

Results in Table 3-1, when compared with the DLs and QLs, can be organized into three groups:

- Beryllium was not detected in the leachate.

- Antimony, cadmium, lead, silver, nickel, and thallium were detected below the QLs.

- Arsenic, barium, chromium, mercury, and selenium were detected in the leachates at concentrations above the QLs.

Results from the TCLP leachate analyses listed in Table 3-1 also include the regulatory limits that may be applied to the Saltstone waste form. Table 3-1 includes the SCHWMR R.61-79.261.24(b) limits above which a waste is to be considered characteristically hazardous for toxicity and the SCHWMR R.61-79.268.48 Universal Treatment Standards (UTS) for hazardous constituents. In addition, Maximum Contaminant Levels (MCL's) from the State Primary Drinking Water Regulations $^{2}$ also have been included in Table 3-1. By comparing the sample results and the regulatory limits in Table 3-1, the following conclusions can be made:

- The saltstone waste form was not characteristically hazardous for toxicity.

- The leachate metals concentrations were below the Nonwastewater Standard for all of the metals.

- Antimony, barium, beryllium, cadmium, chromium, lead, silver and thallium were below the MCL's.

- Arsenic, mercury, and selenium exceeded the MCL.

- Nickel does not have a MCL.

The MCL is the limit for a constituent in drinking water. The MCL is used to determine the class of landfill required. At 10x MCL, a Class 3 landfill is required. The SDF vaults are permitted as a Class 3 landfill. None of the analyses were greater than 10x the MCL. The results for the TCLP Leachate RCRA metals are reported on SCDHEC form DHEC3657 (Industrial RCRA TCLP Metals) included in the appendix to this report.

\subsection{TCLP Leachate Results for Other Inorganic Species}

Other inorganic species are present in the Saltstone samples that while not specifically listed as hazardous also have limits. These species include aluminum, boron, chloride, cobalt, copper, fluoride, iron, lithium, manganese, molybdenum, nitrate as Nitrogen $(\mathrm{N})$, nitrite as $\mathrm{N}$, strontium, sulfate, uranium, and zinc. These limits ${ }^{2}$ include MCL, secondary maximum contaminant limits (SMCL) and tap water limits (TW). Table 3-2 lists the results of the TCLP leachate for these species, the DL and QL for the species plus the specific limit for each of these species. The average for those species greater than the detection limit is also reported. The reported uncertainties are based on one standard deviation for the triplicate results.

\footnotetext{
${ }^{2}$ Regulations 61-58 through 61-58.15 are promulgated pursuant to S.C. Code Sections 44-55-10 et seq. and are collectively known as the State Primary Drinking Water Regulations.
} 
Table 3-2 TCLP Leachate Results for Other Inorganic Species of Interest

\begin{tabular}{|c|c|c|c|c|c|c|c|}
\hline- & \multicolumn{3}{|c|}{ Sample Results (mg/L) } & \multirow{2}{*}{$\begin{array}{c}\text { Average } \\
\text { mg/L }\end{array}$} & \multicolumn{2}{|c|}{ Analytical limits } & \multirow{2}{*}{$\begin{array}{c}\begin{array}{c}\text { Regulatory } \\
\text { Limits }\end{array} \\
\text { MCL }\end{array}$} \\
\hline SRS ID & $\begin{array}{c}\text { 11114-SS- } \\
\text { Vault1 }\end{array}$ & $\begin{array}{c}\text { 11114-SS- } \\
\text { Vault2 }\end{array}$ & $\begin{array}{c}\text { 11114-SS- } \\
\text { Vault3 }\end{array}$ & & $\begin{array}{l}\text { Detection } \\
\text { Limit }\end{array}$ & $\begin{array}{l}\text { Quantitation } \\
\text { Limit }\end{array}$ & \\
\hline B\&W ID & 1108010-01 & 1108010-02 & 1108010-03 & - & mg/L & $\mathrm{mg} / \mathrm{L}$ & $\mathrm{mg} / \mathrm{L}$ \\
\hline Fluoride & $<2.5$ & $<2.5$ & $<2.5$ & $<2.5$ & 2.5 & 5 & 4 \\
\hline Nitrate as $\mathbf{N}$ & 8392 & 3662 & 5599 & $5880 \pm 2380$ & 2.5 & 5 & 10 \\
\hline Nitrite as $\mathbf{N}$ & 181 & 193 & 194 & $189 \pm 7$ & 2.5 & 5 & 1 \\
\hline $\begin{array}{l}\text { Nitrate+Nitrite } \\
\text { as N }\end{array}$ & 8573 & 3855 & 5793 & $6070 \pm 2370$ & 2.5 & 5 & 10 \\
\hline Uranium & $* 0.00065$ & $* 0.0083$ & $* 0.0004$ & $* 0.003 \pm 0.004$ & ND & ND & 0.03 \\
\hline- & - & - & - & - & - & - & $\begin{array}{c}\text { SMCL, } \\
\mathrm{mg} / \mathrm{L}\end{array}$ \\
\hline Aluminum & ${ }^{E} 2.21$ & ${ }^{\mathrm{E}} 1.6$ & $\mathrm{E}_{1.77}$ & $\mathrm{E}_{1.86 \pm 0.31}$ & 0.0037 & 0.0555 & 0.2 \\
\hline Chloride & 26.9 & 28.2 & 30.4 & $28.5 \pm 1.8$ & 2.5 & 5 & 250 \\
\hline Copper & ${ }^{\mathrm{B}} 0.0206$ & ${ }^{\mathrm{B}} 0.0216$ & ${ }^{\mathrm{B}} 0.023$ & ${ }^{\mathrm{B}} 0.022 \pm 0.001$ & 0.0009 & 0.0555 & 1 \\
\hline Iron & 0.193 & 0.292 & 0.212 & $0.23 \pm 0.05$ & 0.0096 & 0.0555 & 0.3 \\
\hline Manganese & 0.00296 & ${ }^{\mathrm{B}} 0.00177$ & ${ }^{\mathrm{B}} 0.00182$ & ${ }^{\mathrm{B}} 0.0022 \pm 0.0007$ & 0.0005 & 0.00278 & 0.05 \\
\hline Sulfate & 166 & 163 & 179 & $169 \pm 8.5$ & 2.5 & 5 & 250 \\
\hline Zinc & $<0.046$ & $<0.046$ & $<0.046$ & $<0.046$ & 0.046 & 0.0555 & 5 \\
\hline- & - & - & - & - & - & - & $\mathrm{TW}, \mathrm{mg} / \mathrm{L}$ \\
\hline Boron & 0.806 & 0.688 & 0.755 & $0.75 \pm 0.06$ & ND & 0.0555 & 7.3 \\
\hline Cobalt & $<0.00012$ & $<0.00012$ & $<0.00012$ & $<0.00012$ & 0.00012 & 0.055 & 0.011 \\
\hline Lithium & 0.87 & 0.825 & 0.864 & $0.85 \pm 0.02$ & 0.0056 & 0.0555 & 0.073 \\
\hline Molybdenum & 0.514 & 0.481 & 0.511 & $0.50 \pm 0.02$ & 0.001 & 0.0555 & 0.18 \\
\hline Strontium & 0.325 & 0.362 & 0.332 & $0.34 \pm 0.02$ & 0.0013 & 0.0555 & 22 \\
\hline & $\begin{array}{l}\text { - Indicates a lo } \\
\mathrm{B} \text { Analyte is } \mathrm{P} \\
\mathrm{E} \text { Associated } \\
{ }^{*} \text { Associated I } \\
\text { ND B\&W has }\end{array}$ & $\begin{array}{l}\text { tion in the tab } \\
\text { ent at a conce } \\
\text { al Dilution is } \\
\text { licate is outs } \\
\text { t yet determi }\end{array}$ & $\begin{array}{l}\text { for which an } \\
\text { ation above th } \\
\text { tside percent } \\
\text { percent differ } \\
\text { values for the }\end{array}$ & $\begin{array}{l}\text { ry would not be a } \\
\text { DL but less than } \\
\text { ference quality co } \\
\text { ce quality control } \\
\text { analytical limits. }\end{array}$ & $\begin{array}{l}\text { ropriate. } \\
\text { QL. } \\
\text { rol criteria. } \\
\text { riteria. }\end{array}$ & & \\
\hline
\end{tabular}

Results in Table 3-2, when compared with the DLs and QLs, can be organized into three groups:

- Fluoride, cobalt and zinc were not detected in the leachate.

- Copper and manganese were detected below the QLs.

- Nitrate, nitrite, aluminum, chloride, iron, sulfate, boron, lithium, molybdenum, and strontium were detected in the leachates at concentrations above the QLs.

By comparing the sample results and the regulatory limits in Table 3-2, the following conclusions can be made:

- $\quad$ Fluoride and uranium were below the MCL's.

- Chloride, copper, iron, manganese, sulfate and zinc were below the SMCL's.

- Boron, cobalt, and strontium were below the TW's.

- Nitrate, nitrite, and sum of nitrate and nitrite exceeded the MCL. 
- Aluminum exceeded the SMCL.

- Lithium and molybdenum exceeded the TW.

As previously mentioned, the MCL is used to determine the class of landfill required. At 10x MCL, a Class 3 landfill is required. The SDF vaults are permitted as a Class 3 landfill. Based on the TCL leachate results for nitrate and nitrite, these species exceed the MCL by greater than 10x. The results for the other inorganic species are also reported on SCDHEC form DHEC3657 (Industrial RCRA - TCLP Metals) included in the appendix to this report.

The reported TCLP leachate values for nitrate and nitrite were compared to the concentrations measured on the Tank 50 sample (WAC) ${ }^{(6)}$ used to prepare the Vault classification samples. The ratio of nitrate as $\mathrm{N}$ to nitrite as $\mathrm{N}$ was 6.9 while the ratio from the average values in Table $3-2$ is 31.2 which suggests either an issue with the anion analysis or with the sample preparation. A review of the contract lab reports shows that the TCLP extract was tested for $\mathrm{pH}$ and that nitric acid was evidently added to change the $\mathrm{pH}$ of the extract from 11 to less than 2 . This would increase the nitrate concentration while the acidic $\mathrm{pH}$ would lead to conversion of the nitrite to nitrous acid ( $\mathrm{pKa}=3.37$ ) followed by decomposition of the nitrous acid. To better define the relative amounts of nitrate and nitrite in the vault classification samples a total analysis of the anions was obtained by performing a two hour water leach of the vault classification samples followed by ion chromatography. The total anion results are shown in Table 3-3. The nitrate to nitrite ratio from the average values in Table 3-3 is 6.8 and is in good agreement with the ratio from the WAC analysis. The concentration of nitrite in the TCLP leachate in Table 3-2 should be viewed as a not less than value and can still be used to evaluate the need for a Class 3 landfill independent of the nitrate result as the nitrite result is more than $190 \mathrm{x}$ the MCL for nitrite.

Table 3-3 Total Anion Results Based on Water Leach of Saltstone Vault Classification Samples

\begin{tabular}{|c|c|c|c|c|c|c|}
\hline- & \multicolumn{3}{|c|}{ Sample Results (mg/Kg) } & \multirow{2}{*}{$\frac{\text { Average }}{(\mathrm{mg} / \mathrm{Kg})}$} & \multicolumn{2}{|c|}{ Analytical limits } \\
\hline SRS ID & $\begin{array}{c}\text { 11114-SS- } \\
\text { Vault1 }\end{array}$ & $\begin{array}{c}\text { 11114-SS- } \\
\text { Vault2 }\end{array}$ & $\begin{array}{c}\text { 11114-SS- } \\
\text { Vault3 }\end{array}$ & & $\begin{array}{c}\text { Detection } \\
\text { Limit }\end{array}$ & $\begin{array}{c}\text { Quantitation } \\
\text { Limit }\end{array}$ \\
\hline B\&W ID & $1106010-01$ & $1106010-02$ & 1106010-03 & - & $(\mathrm{mg} / \mathrm{Kg})$ & (mg/Kg) \\
\hline Chloride & 12.99 & 12.8 & 65.03 & $30.3 \pm 30$ & 0.5 & 1.0 \\
\hline Fluoride & 15.38 & 18.34 & 13.35 & $15.7 \pm 2.5$ & 0.5 & 1.0 \\
\hline Nitrate as $\mathbf{N}$ & 3478 & 5206 & 5656 & $4780 \pm 1150$ & 0.5 & 1.0 \\
\hline Nitrite as $\mathbf{N}$ & 483 & 837 & 799 & $706 \pm 194$ & 0.5 & 1.0 \\
\hline $\begin{array}{c}\text { Nitrate/Nitrite } \\
\text { as N }\end{array}$ & 3961 & 6043 & 6455 & $5486 \pm 1337$ & 0.5 & 1.0 \\
\hline Sulfate & 1285 & 1791 & 2276 & $1784 \pm 496$ & 0.5 & 1.0 \\
\hline
\end{tabular}

- Indicates a location in the table for which an entry would not be appropriate.

\subsection{TCLP Leachate Results for Benzene, Toluene, 1-Butanol and Phenol}

GEL reports VOA and general chemistry analyses on the organics in the TCLP leachate samples. Table 3-4 lists the results for the organic species measured in the TCLP leachate of the vault samples for the $2^{\text {nd }}$ quarter 2011. If the concentrations of benzene, toluene, 1-butanol and phenol are not detected or below the detection limit the result is reported as less than the detection limit. In addition to the results, Detection Limits (DLs) and Quantitation Limits (QLs) have been given. The DL is the minimum concentration of an analyte that can be identified, measured, and 
reported with 99\% confidence that the concentration is above zero. The DL values given in Table 3-4 are the results from this study adjusted for sample dilution. The QL is the lowest level at which an analyte may be accurately and reproducibly quantitated.

Table 3-4 TCLP Leachate Results for Organic Species of Interest

\begin{tabular}{|c|c|c|c|c|c|c|c|c|}
\hline- & Methods & \multicolumn{3}{|c|}{ Sample Results (mg/L) } & \multirow{2}{*}{$\begin{array}{c}\text { Average } \\
(\mathrm{mg} / \mathrm{L})\end{array}$} & \multicolumn{2}{|c|}{ Analytical limits } & \multirow{2}{*}{$\begin{array}{c}\begin{array}{c}\text { Regulatory } \\
\text { Limits }\end{array} \\
\text { MCL }\end{array}$} \\
\hline SRS ID & - & $\begin{array}{l}\text { 11114-SS- } \\
\text { Vault1 }\end{array}$ & $\begin{array}{l}\text { 11114-SS- } \\
\text { Vault2 }\end{array}$ & $\begin{array}{l}\text { 11114-SS- } \\
\text { Vault3 }\end{array}$ & & $\begin{array}{l}\text { Detection } \\
\text { Limit }\end{array}$ & $\begin{array}{l}\text { Quantitation } \\
\text { Limit }\end{array}$ & \\
\hline $\begin{array}{c}\text { GEL Lab } \\
\text { ID }\end{array}$ & - & 284341001 & 284341002 & 284341003 & - & $(\mathrm{mg} / \mathrm{L})$ & $(\mathrm{mg} / \mathrm{L})$ & $(\mathrm{mg} / \mathrm{L})$ \\
\hline Benzene & 8260B & $<0.003$ & $<0.003$ & $<0.003$ & $<0.003$ & 0.003 & 0.01 & 0.005 \\
\hline 1-Butanol & 8260B & $<0.15$ & $<0.15$ & $<0.15$ & $<0.15$ & 0.15 & 0.5 & 3.7 \\
\hline $\begin{array}{l}\text { GEL Lab } \\
\text { ID }\end{array}$ & - & 284341004 & 284341005 & 284341006 & $(\mathrm{mg} / \mathrm{L})$ & $(\mathrm{mg} / \mathrm{L})$ & $(\mathrm{mg} / \mathrm{L})$ & $(\mathrm{mg} / \mathrm{L})$ \\
\hline Phenol & 9066 & 0.00515 & $<0.0016$ & 0.00874 & $\mathrm{Y}_{0.007 \pm 0.003}$ & 0.0016 & 0.005 & 11 \\
\hline
\end{tabular}

- Indicates a location in the table for which an entry would not be appropriate.

${ }^{\mathrm{Y}}$ Analyte was measured in the TCLP blank at levels greater than the three samples.

The results of the VOA showed that the benzene, toluene and 1-butanol were not detected and are therefore shown in Table 3-4 as less than detection limit values. Phenol was detected in two of the three vault samples but was also detected in the TCLP blank (see section 3.6.1) at levels greater than the reported values for the two measured amounts. The conclusion is that the organic species of interest were less than the MCL for each of the species. The results for the VOA analysis are reported on form DHEC3658 and for phenol analysis on form DHEC3659 and are included in the appendix to this report.

\subsection{TCLP Leachate Results for Radionuclides}

The TCLP leachate radionuclide results are shown in Table 3-5. The table includes the MCLs for those measurements that are specifically identified in the SCDHEC regulations. The MDA are the method detection limits from standard practices based on counting statistics.

Table 3-5 Radionuclide Results for the TCLP Leachate

\begin{tabular}{|c|c|c|c|c|c|c|c|c|}
\hline- & - & \multicolumn{2}{|c|}{ Sample $1(p C i / L)$} & \multicolumn{2}{|c|}{ Sample $2(p C i / L)$} & \multicolumn{2}{|c|}{ Sample 3 (pCi/L) } & Average (pCi/L) \\
\hline Date & - & \multicolumn{2}{|c|}{$4 / 5 / 2011$} & \multicolumn{2}{|c|}{$4 / 5 / 2011$} & \multicolumn{2}{|c|}{$4 / 5 / 2011$} & - \\
\hline SRS ID & - & \multicolumn{2}{|c|}{ 11114-SS-Vault-1 } & \multicolumn{2}{|c|}{ 11114-SS-Vault-2 } & \multicolumn{2}{|c|}{ 11114-SS-Vault-3 } & - \\
\hline $\begin{array}{c}\text { BW-TSG } \\
\text { ID } \\
\end{array}$ & - & \multicolumn{2}{|c|}{ 1108010-01 } & \multicolumn{2}{|c|}{ 1108010-02 } & \multicolumn{2}{|c|}{ 1108010-03 } & - \\
\hline $\begin{array}{l}\text { GEL Lab } \\
\text { ID }\end{array}$ & - & \multicolumn{2}{|c|}{284341004} & \multicolumn{2}{|c|}{284341005} & \multicolumn{2}{|c|}{284341006} & - \\
\hline Analyte & $\begin{array}{c}\text { MCL } \\
(\mathrm{pCi} / \mathrm{L})\end{array}$ & MDA & Result & MDA & Result & MDA & Result & Average (pCi/L) \\
\hline Gross $\alpha$ & 15 & $2.0 \mathrm{E}+03$ & $<2.0 \mathrm{E}+03$ & $1.7 \mathrm{E}+03$ & $<1.7 \mathrm{E}+03$ & $1.7 \mathrm{E}+03$ & $<1.7 \mathrm{E}+03$ & $<1.7 \mathrm{E}+03$ \\
\hline Gross $\beta$ & - & $1.4 \mathrm{E}+03$ & $1.7 \mathrm{E}+07$ & $1.4 \mathrm{E}+03$ & $1.8 \mathrm{E}+07$ & $1.2 \mathrm{E}+03$ & $1.9 \mathrm{E}+07$ & $(1.8 \pm 0.1) \mathrm{E}+07$ \\
\hline${ }^{3} \mathbf{H}$ & - & $5.7 \mathrm{E}+02$ & $1.7 \mathrm{E}+03$ & $5.7 \mathrm{E}+02$ & $1.1 \mathrm{E}+03$ & $5.7 \mathrm{E}+02$ & $8.4 \mathrm{E}+02$ & $(1.2 \pm 0.5) \mathrm{E}+03$ \\
\hline${ }^{60} \mathrm{Co}$ & - & 76 & $<76$ & $4.0 \mathrm{E}+02$ & $<4.0 \mathrm{E}+02$ & 65 & $<65$ & $<65$ \\
\hline
\end{tabular}


SRNL-STI-2011-00561

Revision 0

\begin{tabular}{|c|c|c|c|c|c|c|c|c|}
\hline- & - & \multicolumn{2}{|c|}{ Sample $1(p C i / L)$} & \multicolumn{2}{|c|}{ Sample 2 (pCi/L) } & \multicolumn{2}{|c|}{ Sample $3(p C i / L)$} & Average (pCi/L) \\
\hline Date & - & \multicolumn{2}{|c|}{$4 / 5 / 2011$} & \multicolumn{2}{|c|}{$4 / 5 / 2011$} & \multicolumn{2}{|c|}{$4 / 5 / 2011$} & - \\
\hline SRS ID & - & \multicolumn{2}{|c|}{ 11114-SS-Vault-1 } & \multicolumn{2}{|c|}{ 11114-SS-Vault-2 } & \multicolumn{2}{|c|}{ 11114-SS-Vault-3 } & - \\
\hline $\begin{array}{c}\text { BW-TSG } \\
\text { ID }\end{array}$ & - & \multicolumn{2}{|c|}{ 1108010-01 } & \multicolumn{2}{|c|}{ 1108010-02 } & \multicolumn{2}{|c|}{ 1108010-03 } & - \\
\hline $\begin{array}{c}\text { GEL Lab } \\
\text { ID }\end{array}$ & - & \multicolumn{2}{|c|}{284341004} & \multicolumn{2}{|c|}{284341005} & \multicolumn{2}{|c|}{284341006} & - \\
\hline Analyte & $\begin{array}{c}\mathrm{MCL} \\
(\mathrm{pCi} / \mathrm{L})\end{array}$ & MDA & Result & MDA & Result & MDA & Result & Average (pCi/L) \\
\hline${ }^{90} \mathrm{Sr}$ & - & $2.9 \mathrm{E}+02$ & $5.1 \mathrm{E}+04$ & $2.7 \mathrm{E}+02$ & $1.1 \mathrm{E}+05$ & $3.0 \mathrm{E}+02$ & $1.4 \mathrm{E}+05$ & $(9.7 \pm 4.3) \mathrm{E}+04$ \\
\hline${ }^{99} \mathrm{Tc}$ & - & $6.5 \mathrm{E}+02$ & $5.6 \mathrm{E}+04$ & $5.7 \mathrm{E}+02$ & $4.3 \mathrm{E}+04$ & $5.9 \mathrm{E}+02$ & $5.4 \mathrm{E}+04$ & $(5.1 \pm 0.7) \mathrm{E}+04$ \\
\hline${ }^{106} \mathrm{Ru}$ & - & $2.2 \mathrm{E}+04$ & $<2.2 \mathrm{E}+04$ & $3.3 E+04$ & $<3.3 \mathrm{E}+04$ & $1.5 \mathrm{E}+04$ & $<1.5 \mathrm{E}+04$ & $<1.5 \mathrm{E}+04$ \\
\hline${ }^{106} \mathrm{Rh}$ & - & $1.5 \mathrm{E}+04$ & $<1.5 \mathrm{E}+04$ & $2.0 \mathrm{E}+04$ & $<2.0 \mathrm{E}+04$ & $1.1 \mathrm{E}+04$ & $<1.1 \mathrm{E}+04$ & $<1.1 \mathrm{E}+04$ \\
\hline${ }^{125} \mathrm{Sb}$ & - & $1.1 \mathrm{E}+04$ & $<1.1 \mathrm{E}+04$ & $1.5 \mathrm{E}+04$ & $<1.5 \mathrm{E}+04$ & $7.7 \mathrm{E}+03$ & $<7.7 \mathrm{E}+03$ & $<7.7 \mathrm{E}+03$ \\
\hline${ }^{137} \mathrm{Cs}$ & - & $3.3 \mathrm{E}+03$ & $1.9 \mathrm{E}+07$ & $1.2 \mathrm{E}+04$ & $1.6 \mathrm{E}+07$ & $2.2 \mathrm{E}+03$ & $1.9 \mathrm{E}+07$ & $(1.8 \pm 0.2) \mathrm{E}+07$ \\
\hline${ }^{137 m b} \mathrm{Ba}$ & - & $3.1 \mathrm{E}+03$ & $1.8 \mathrm{E}+07$ & $1.1 \mathrm{E}+04$ & $1.5 \mathrm{E}+07$ & $2.1 \mathrm{E}+03$ & $1.8 \mathrm{E}+07$ & $(1.7 \pm 0.1) \mathrm{E}+07$ \\
\hline${ }^{147} \mathrm{Pm}$ & - & $1.2 \mathrm{E}+02$ & $<1.2 \mathrm{E}+02$ & $1.1 \mathrm{E}+02$ & ${ }^{z_{2.2}} \mathrm{E}+02$ & $1.1 \mathrm{E}+02$ & ${ }^{z_{1.4}} \mathrm{E}+02$ & $<1.2 \mathrm{E}+02$ \\
\hline${ }^{154} \mathbf{E u}$ & - & $3.70 \mathrm{E}+02$ & $<3.70 \mathrm{e}+02$ & $4.9 \mathrm{E}+02$ & $<4.9 \mathrm{E}+02$ & $3.1 \mathrm{E}+02$ & $<3.1 \mathrm{E}+02$ & $<3.1 \mathrm{E}+02$ \\
\hline${ }^{226} \mathrm{Ra}$ & 5 & $4.4 \mathrm{E}+04$ & $<4.4 \mathrm{E}+04$ & $6.5+04$ & $<6.5 \mathrm{E}+04$ & $4.4 \mathrm{E}+04$ & $<4.4 \mathrm{E}+04$ & $<4.4 \mathrm{E}+04$ \\
\hline${ }^{228} \mathbf{R a}$ & 5 & $3.6 \mathrm{E}+03$ & $<3.6 \mathrm{E}+03$ & $3.9 E+03$ & $<3.9 \mathrm{E}+03$ & $4.7 \mathrm{E}+03$ & $<4.7 \mathrm{E}+03$ & $<3.6 \mathrm{E}+03$ \\
\hline${ }^{238} \mathrm{Pu}$ & - & 16 & $<16$ & 35 & $<35$ & 12 & $<12$ & $<12$ \\
\hline${ }^{239 / 240} \mathrm{Pu}$ & - & 8.5 & $<8.5$ & 13 & $<13$ & 8.3 & $<8.33$ & $<8.3$ \\
\hline${ }^{241} \mathrm{Pu}$ & - & $8.2 \mathrm{E}+02$ & $<8.2 \mathrm{E}+02$ & $1.3 \mathrm{E}+03$ & $<1.3 \mathrm{E}+03$ & $8.0 \mathrm{E}+02$ & $<8.0 \mathrm{E}+02$ & $<8.0 \mathrm{E}+02$ \\
\hline${ }^{241} \mathrm{Am}$ & & 15 & $<15$ & 15 & $<15$ & 11 & $<11$ & $<11$ \\
\hline${ }^{242} \mathrm{Cm}$ & - & 11 & $<11$ & 13 & $<13$ & 9.2 & $<9.2$ & $<9.2$ \\
\hline${ }^{243 / 244} \mathrm{Cm}$ & - & 12 & $<12$ & 4.8 & $<4.8$ & 10 & $<10$ & $<4.8$ \\
\hline
\end{tabular}

- Indicates a location in the table for which an entry would not be appropriate.

$\mathrm{z}$ Result is biased high due to spectral interference therefore excluded from average.

The following conclusions can be made based on the data in Table 3-5:

- The gross alpha and radium isotopes could not be determined to the MCL because of the elevated background which raised the detection limits.

- Most of the beta/gamma activity was from ${ }^{137} \mathrm{Cs}$ and its daughter ${ }^{137 \mathrm{~m}} \mathrm{Ba}$.

\subsection{Quality Assurance for Inorganic Species}

The following subsections include summaries of results from blanks, laboratory control samples, matrix spikes, and matrix spike duplicates. The data package also includes data for calibration verifications, interference checks, and serial dilutions. ${ }^{(8)}$ The quality assurance data reported here is also reported on form DHEC3732 as shown in the appendix to this report.

\subsubsection{Blanks}

Blank concentrations are given in Table 3-6. In the TCLP blanks, the elements that were present at levels above the quantitation limit were lead, selenium, boron, iron, manganese and zinc. Antimony, arsenic, barium, chromium, silver, nickel, aluminum, cobalt, copper and strontium 
were present at levels above their respective DLs, but below their respective QLs. Beryllium, cadmium, mercury, thallium, lithium and molybdenum were found to be below the DLs.

Table 3-6 TCLP Blank

\begin{tabular}{||c||c|c|c||}
\hline Analyte & $\begin{array}{c}\text { TCLP } \\
\text { Blank } \\
\mathbf{m g} / \mathbf{L}\end{array}$ & $\begin{array}{c}\text { Detection } \\
\text { Limit, } \\
\mathbf{m g} / \mathbf{L}\end{array}$ & $\begin{array}{c}\text { Quantitation } \\
\text { Limit, mg/L }\end{array}$ \\
\hline \hline $\mathbf{A s}$ & ${ }^{\mathrm{B}} 0.0018$ & 0.0001 & 0.0056 \\
\hline $\mathbf{B a}$ & ${ }^{\mathrm{B}} 0.0031$ & 0.00044 & 0.0556 \\
\hline $\mathbf{C d}$ & $<0.00011$ & 0.00011 & 0.0056 \\
\hline $\mathbf{C r}$ & ${ }^{\mathrm{B}} 0.00072$ & 0.00031 & 0.01111 \\
\hline $\mathbf{P b}$ & 0.0061 & 0.00048 & 0.00556 \\
\hline $\mathbf{H g}$ & $<0.00007$ & 0.00007 & 0.0002 \\
\hline $\mathbf{S e}$ & ${ }^{\mathrm{E}} 0.0535$ & 0.00024 & 0.0278 \\
\hline $\mathbf{A g}$ & ${ }^{\mathrm{B}} 0.00010$ & 0.00006 & 0.0056 \\
\hline $\mathbf{S b}$ & ${ }^{\mathrm{B}} 0.00023$ & 0.00013 & 0.0111 \\
\hline $\mathbf{B e}$ & $<0.00016$ & 0.00016 & 0.00556 \\
\hline $\mathbf{N i}$ & ${ }^{\mathrm{B}} 0.0056$ & 0.0016 & 0.00556 \\
\hline $\mathbf{T l}$ & $<0.00021$ & 0.00021 & 0.00556 \\
\hline $\mathbf{A l}$ & ${ }^{\mathrm{B}} 0.0345$ & 0.00373 & 0.0555 \\
\hline $\mathbf{B}$ & 0.0802 & $\mathrm{ND}$ & 0.0555 \\
\hline $\mathbf{C o}$ & ${ }^{\mathrm{B}} 0.00013$ & 0.00012 & 0.0555 \\
\hline $\mathbf{C u}$ & ${ }^{\mathrm{B}} 0.0186$ & 0.00087 & 0.0555 \\
\hline $\mathbf{F e}$ & 0.132 & 0.00962 & 0.0555 \\
\hline $\mathbf{L i}$ & $<0.00556$ & 0.00556 & 0.0555 \\
\hline $\mathbf{M n}$ & 0.00441 & 0.00046 & 0.00278 \\
\hline $\mathbf{M o}$ & $<0.00102$ & 0.00102 & 0.0555 \\
\hline $\mathbf{S r}$ & ${ }^{\mathrm{B}} 0.00796$ & 0.00125 & 0.0555 \\
\hline $\mathbf{U}$ & 0.0026 & $\mathrm{ND}$ & $\mathrm{ND}$ \\
\hline $\mathbf{Z n}$ & 0.0606 & 0.0461 & 0.0555 \\
\hline $\mathrm{An}$ & ${ }^{0} 056$ \\
\hline
\end{tabular}

${ }^{\mathrm{B}}$ Analyte is present at a concentration above the DL but less than the QL.

${ }^{\mathrm{E}}$ Associated Serial Dilution is outside percent difference quality control criteria. ND B\&W has not yet determined a value for this analytical limit.

\subsubsection{Laboratory Control Samples}

Results from the Laboratory Control Sample (LCS) are given in Table 3-7. The LCS recoveries met USEPA SW-846 acceptance limits for all elements and anions. Laboratory Control Samples are clean aqueous solutions analyzed to assure integrity of the analytical technique exclusive of matrix effects. 
Table 3-7 Laboratory Control Sample for Inorganics

\begin{tabular}{|c|c|c|c|}
\hline \multirow{2}{*}{$\begin{array}{c}\text { Analyte } \\
-\end{array}$} & \multicolumn{2}{|c|}{ Laboratory Control $(\mu \mathrm{g} / \mathrm{L})$} & \multirow{2}{*}{$\frac{\text { Recovery }(\%)}{(80-120)}$} \\
\hline & TRUE & Measured & \\
\hline As & 719 & 704 & 98 \\
\hline $\mathbf{B a}$ & 463 & 459 & 99 \\
\hline Cd & 476 & 465 & 98 \\
\hline $\mathrm{Cr}$ & 162 & 163 & 101 \\
\hline $\mathbf{P b}$ & 280 & 291 & 104 \\
\hline Hg & 5.4 & 6.41 & 119 \\
\hline Se & 1000 & 965 & 96 \\
\hline Ag & 194 & 190 & 98 \\
\hline Sb & 328 & 311 & 95 \\
\hline $\mathbf{B e}$ & 136 & 116 & 85 \\
\hline $\mathbf{N i}$ & 533 & 524 & 98 \\
\hline Tl & 142 & 134 & 94 \\
\hline Al & 2690 & 2460 & 91 \\
\hline B & 1590 & 1460 & 92 \\
\hline Co & 275 & 254 & 92 \\
\hline $\mathbf{C u}$ & 316 & 296 & 94 \\
\hline $\mathbf{F e}$ & 2310 & 2190 & 95 \\
\hline Mn & 568 & 522 & 92 \\
\hline Mo & 387 & 354 & 91 \\
\hline $\mathrm{Sr}$ & 202 & 181 & 90 \\
\hline $\mathbf{Z n}$ & 287 & 263 & 92 \\
\hline Chloride & 1000 & 1030 & 102.7 \\
\hline Fluoride & 1000 & 870 & 86.5 \\
\hline $\begin{array}{c}\text { Nitrate as } \\
\mathbf{N}\end{array}$ & 1000 & 980 & 97.7 \\
\hline $\begin{array}{c}\text { Nitrite as } \\
\mathbf{N}\end{array}$ & 1000 & 1020 & 101.8 \\
\hline Sulfate & 1000 & 990 & 98.6 \\
\hline
\end{tabular}

\subsubsection{Matrix Spikes}

Results from analysis of the matrix spike (MS) and matrix spike duplicates (MSD) are given in Table 3-8 for the RCRA metals, Table 3-9 for the other metals, and Table 3-10 for the anions. The initial concentrations in the second column are reproduced from Table 3-1 and Table 3-2 for the specific sample used for the matrix. These results show that: 
- The percent recoveries (\%R) obtained from the MS analyses met the recommended quality control acceptance criteria for percent recoveries (70 - 130\%) for all applicable analytes.

- The percent recoveries (\%R) obtained from the MSD analyses met the recommended quality control acceptance criteria for percent recoveries (70 - 130\%) for all applicable analytes.

- The RPD(s) between the MS and MSD met the acceptance limits (0 - 20\%).

Table 3-8 TCLP Leachates Matrix Spike and Duplicate Results

\begin{tabular}{|c|c|c|c|c|c|c|c|}
\hline \multirow{2}{*}{$\begin{array}{c}\text { Analyte } \\
-\end{array}$} & \multicolumn{2}{|c|}{$\begin{array}{c}\text { Initial Concentrations } \\
\qquad(\mathrm{mg} / \mathrm{L}) \\
\end{array}$} & \multicolumn{2}{|c|}{$\begin{array}{l}\text { Spiked Sample } \\
\qquad(\mathrm{mg} / \mathrm{L})\end{array}$} & \multicolumn{2}{|c|}{ Recovery (\%) } & \multirow{2}{*}{$\begin{array}{c}- \\
\text { RPD } \\
\text { (\%)- }\end{array}$} \\
\hline & $\begin{array}{c}\text { B\&W ID } \\
1105017-01 \mathrm{~A}\end{array}$ & $\begin{array}{l}\text { Spike } \\
\text { Added }\end{array}$ & Spike & $\begin{array}{c}\text { Spike } \\
\text { Duplicate }\end{array}$ & Spike & $\begin{array}{c}\text { Spike } \\
\text { Duplicate }\end{array}$ & \\
\hline Sb & ${ }^{\mathrm{B}} 3.0$ & 1000 & 937 & 926 & 93 & 92 & 1 \\
\hline As & 13.4 & 500 & 528 & 569 & 103 & 111 & 7 \\
\hline $\mathbf{B a}$ & 234 & 2500 & 2687 & 2708 & 98 & 99 & 1 \\
\hline Cd & ${ }^{\mathrm{B}} 0.32$ & 250 & 218 & 216 & 87 & 86 & 1 \\
\hline $\mathrm{Cr}$ & 18.3 & 1000 & 926 & 927 & 91 & 91 & 0 \\
\hline $\mathbf{P b}$ & ${ }^{\mathrm{B}} 2.7$ & 500 & 543 & 543 & 108 & 108 & 0 \\
\hline $\mathrm{Hg}$ & 18.6 & 5 & 24.4 & 23.1 & 116 & 90 & 5.5 \\
\hline Se & ${ }^{\mathrm{E}} 159$ & 250 & 380 & 409 & 88 & 100 & 7 \\
\hline Ag & ${ }^{\mathrm{B}} 0.14$ & 250 & 190 & 190 & 76 & 76 & 0 \\
\hline $\mathrm{Be}$ & $<0.16$ & 250 & 205 & 203 & 82 & 81 & 1 \\
\hline $\mathbf{N i}$ & ${ }^{\mathrm{B}} 3.5$ & 1000 & 850 & 848 & 85 & 84 & 0 \\
\hline Tl & ${ }^{\mathrm{B}} 0.26$ & 250 & 262 & 263 & 105 & 105 & 0 \\
\hline
\end{tabular}

- Indicates a location in the table for which an entry would not be appropriate.

${ }^{B}$ Analyte is present at a concentration above the DL but less than the QL.

${ }^{\mathrm{E}}$ Associated Serial Dilution is outside percent difference quality control criteria.

Table 3-9 Matrix Spike and Duplicate Results for Other Metals of Interest

\begin{tabular}{|c|c|c|c|c|c|c|c|}
\hline \multirow{2}{*}{$\begin{array}{c}\text { Analyte } \\
-\end{array}$} & \multicolumn{2}{|c|}{$\begin{array}{c}\text { Initial Concentrations } \\
\qquad(\mu \mathrm{g} / \mathrm{L})\end{array}$} & \multicolumn{2}{|c|}{$\begin{array}{l}\text { Spiked Sample } \\
\qquad(\mu \mathrm{g} / \mathrm{L})\end{array}$} & \multicolumn{2}{|c|}{ Recovery (\%) } & \multirow[t]{2}{*}{$\begin{array}{l}\text { RPD } \\
(\%)\end{array}$} \\
\hline & $\begin{array}{c}\text { B\&W ID } \\
\text { 1108010- } \\
\text { 03RE1 }\end{array}$ & $\begin{array}{l}\text { Spike } \\
\text { Added }\end{array}$ & Spike & $\begin{array}{c}\text { Spike } \\
\text { Duplicate }\end{array}$ & Spike & $\begin{array}{c}\text { Spike } \\
\text { Duplicate }\end{array}$ & \\
\hline Al & 1770 & 997 & 2560 & 2680 & 79 & 91 & 4.58 \\
\hline B & 755 & 997 & 1580 & 1610 & 83 & 86 & 1.88 \\
\hline Co & $<0.12$ & 2000 & 1700 & 1740 & 85 & 87 & 2.33 \\
\hline
\end{tabular}




\begin{tabular}{|c|c|c|c|c|c|c|c|}
\hline \multirow{2}{*}{$\begin{array}{c}\text { Analyte } \\
-\end{array}$} & \multicolumn{2}{|c|}{$\begin{array}{c}\text { Initial Concentrations } \\
\qquad(\mu \mathrm{g} / \mathrm{L})\end{array}$} & \multicolumn{2}{|c|}{$\begin{array}{c}\text { Spiked Sample } \\
(\mu \mathrm{g} / \mathrm{L})\end{array}$} & \multicolumn{2}{|c|}{ Recovery (\%) } & \multirow{2}{*}{$\begin{array}{c}\text { RPD } \\
(\%) \\
-\end{array}$} \\
\hline & $\begin{array}{c}\text { B\&W ID } \\
\text { 1108010- } \\
\text { 03RE1 }\end{array}$ & $\begin{array}{l}\text { Spike } \\
\text { Added }\end{array}$ & Spike & $\begin{array}{c}\text { Spike } \\
\text { Duplicate }\end{array}$ & Spike & $\begin{array}{c}\text { Spike } \\
\text { Duplicate }\end{array}$ & \\
\hline $\mathbf{C u}$ & ${ }^{B} 23$ & 2000 & 1640 & 1660 & 81 & 82 & 1.21 \\
\hline $\mathrm{Fe}$ & 212 & 6000 & 5380 & 5560 & 86 & 89 & 3.29 \\
\hline $\mathbf{L i}$ & 864 & 997 & 1720 & 1720 & 86 & 86 & 0 \\
\hline Mn & $\mathrm{B}_{2}$ & 2000 & 1680 & 1700 & 84 & 85 & 1.18 \\
\hline Mo & 511 & 1500 & 2130 & 2180 & 108 & 111 & 2.32 \\
\hline $\mathrm{Sr}$ & 332 & 997 & 1240 & 1270 & 91 & 94 & 2.39 \\
\hline $\mathbf{U}$ & 0.4 & 722 & 774 & 792 & 107.1 & 109.6 & 2.3 \\
\hline $\mathbf{Z n}$ & $<47$ & 3500 & 2590 & 2640 & 74 & 75 & 1.91 \\
\hline
\end{tabular}

- Indicates a location in the table for which an entry would not be appropriate.

B Analyte is present at a concentration above the DL but less than the QL.

Table 3-10 Matrix Spike and Spike Duplicate Results for Anions

\begin{tabular}{||c|c|c|c|c|c|c|c||}
\hline \hline \multirow{2}{*}{ Anion } & \multicolumn{2}{|c|}{$\begin{array}{c}\text { Initial Concentrations } \\
(\mathbf{m g} / \mathbf{L})\end{array}$} & \multicolumn{2}{c|}{$\begin{array}{c}\text { Spiked Sample } \\
(\mathbf{m g} / \mathbf{L})\end{array}$} & \multicolumn{2}{|c||}{ Recovery (\%) } & $\begin{array}{c}\text { RPD } \\
(\%)\end{array}$ \\
\hline- & $\begin{array}{c}\text { B\&W ID } \\
\mathbf{1 1 0 8 0 1 0 - 0 1}\end{array}$ & $\begin{array}{c}\text { Spike } \\
\text { Added }\end{array}$ & Spike & $\begin{array}{c}\text { Spike } \\
\text { Duplicate }\end{array}$ & Spike & $\begin{array}{c}\text { Spike } \\
\text { Duplicate }\end{array}$ & - \\
\hline \hline Chloride & 0.10 & 1.0 & 1.02 & 1.01 & 92 & 90 & 1.2 \\
\hline Fluoride & 0.00 & 1.0 & 0.86 & 0.88 & 86 & 88 & 2.2 \\
\hline $\begin{array}{c}\text { Nitrate } \\
\text { as N }\end{array}$ & 8.39 & 1.0 & 9.56 & 9.66 & 116 & 127 & 1.1 \\
\hline $\begin{array}{c}\text { Nitrite as } \\
\mathbf{N}\end{array}$ & 0.21 & 1.0 & 1.22 & 1.20 & 100 & 99 & 1.3 \\
\hline Sulfate & 0.23 & 1.0 & 1.14 & 1.16 & 91 & 93 & 1.8 \\
\hline \hline
\end{tabular}

\subsubsection{Calibration Information}

- All initial calibration requirements have been met for this sample delivery group (SDG).

- All Contract Required Reporting Limit standard(s) met the referenced advisory control limits with the exception of cadmium and selenium.

- All interference check samples associated with this SDG met the established acceptance criteria.

- All continuing calibration blanks bracketing this batch met the established acceptance criteria except for selenium and thallium.

- All continuing calibration verifications bracketing this SDG met the acceptance criteria. 


\subsubsection{Radionuclide Quality Assurance}

The quality assurance for the radionuclide measurements on the TCLP leachate was:

- All duplicate measurement replicate error ratios (RER) met the required limit $(<3)$ with the exception of ${ }^{238} \mathrm{Pu}$ (4.8).

- All Laboratory Control Samples met the required limit (70\%-125\%) with the exception of ${ }^{239} \mathrm{Pu} /{ }^{240} \mathrm{Pu}$ (133\% recovery) and ${ }^{241} \mathrm{Pu}(155 \%$ recovery).

- All matrix spikes met the required limit (60\%-140\%) with the exception of gross alpha which was measured at $210 \%$.

- All batch blanks met the required criteria (calculated activity $<1.65$ times the total propagated uncertainty or sample activity $>5 x$ the blank activity) with the exception of ${ }^{244} \mathrm{Cm}$.

- All tracer recoveries met the required limit (40\%-110\%).

\subsection{Quality Assurance for Organic Species}

The following subsections include summaries of results for the organic species from blanks, laboratory control samples, matrix spikes, and matrix spike duplicates. The data package for this task also includes data for calibration verifications, interference checks, and serial dilutions. The quality assurance data reported here is also reported on form DHEC3732 as shown in the appendix to this report.

\subsubsection{Blanks}

Blank concentrations are given in Table 3-11 for the Method Blank. Target analytes were not detected in the Method Blank. The Method Blanks analyzed with this Sample Delivery Group (SDG) met the acceptance criteria. Also reported are the tracer/surrogate compounds spiked into all of the analyses to verify acceptable operation of the analytical method.

Table 3-11 VOA Method Blank Results

\begin{tabular}{|c|c|c|c|}
\hline Analyte & Analytes (mg/L) & Surrogate, $(\mu \mathrm{g} / \mathrm{L})$ & Surrogate Recovery, \% \\
\hline Benzene & $\mathrm{U}_{\mathrm{ND}}$ & -- & -- \\
\hline Toluene & ${ }^{\mathrm{U}} \mathrm{ND}$ & -- & -- \\
\hline 1-Butanol & ${ }^{\mathrm{U}} \mathrm{ND}$ & -- & -- \\
\hline **1,2-Dichloroethane-d4 & -- & 50.8 & 102 \\
\hline **Bromofluorobenzene & -- & 48.6 & 97.1 \\
\hline$* *$ Toluene-d8 & -- & 48.5 & 97 \\
\hline
\end{tabular}

- Indicates a location in the table for which an entry would not be appropriate.

${ }^{\mathrm{U}}$ Final concentration of the analyte was found to be below the DL.

** - Surrogates added to VOA analysis

ND - Not Detectable

Blank concentrations are given in Table 3-12 for the TCLP Blank which was GEL sample 284341007. Target analytes were not detected in the TCLP Blank. The Method Blanks analyzed with this Sample Delivery Group (SDG) met the acceptance criteria. Surrogate recoveries from the TCLP Blank were within acceptance limits. 
Table 3-12 VOA TCLP Blank Results

\begin{tabular}{|c|c|c|c|}
\hline Analyte & Analytes (mg/L) & Surrogate, $(\mu \mathrm{g} / \mathrm{L})$ & Surrogate Recovery, \% \\
\hline Benzene & ${ }^{\mathrm{U}} \mathrm{ND}$ & -- & -- \\
\hline Toluene & ${ }^{\mathrm{U}} \mathrm{ND}$ & -- & -- \\
\hline 1-Butanol & ${ }^{\mathrm{U}} \mathrm{ND}$ & -- & -- \\
\hline **1,2-Dichloroethane-d4 & -- & 51.3 & 103 \\
\hline$* *$ Bromofluorobenzene & -- & 49.9 & 99.8 \\
\hline **Toluene-d8 & -- & 49.1 & 98.1 \\
\hline
\end{tabular}

The results of the Method Blank and TCLP Blank are shown in Table 3-13. Phenol was not detected in the Method Blank but was measured in the TCLP Blank at about the same level as was measured in the TCLP leachates.

Table 3-13 Method and TCLP Blanks for Phenol

\begin{tabular}{||c|c|c|c|c||}
\hline Analyte & $\begin{array}{c}\text { Method } \\
\text { Blank } \\
(\mu \mathrm{g} / \mathrm{kg})\end{array}$ & $\begin{array}{c}\text { TCLP Blank } \\
(\mu \mathrm{gg} / \mathrm{L})\end{array}$ & $\begin{array}{c}\text { Detection } \\
\text { Limit } \\
(\mu \mathrm{g} / \mathrm{L})\end{array}$ & $\begin{array}{c}\text { Quantitation } \\
\text { Limit }(\mu \mathrm{g} / \mathrm{L})\end{array}$ \\
\hline $\begin{array}{c}\text { GEL } \\
\text { Sample \# }\end{array}$ & -- & 284341007 & -- & -- \\
\hline Phenol & U ND & 12.0 & 1.6 & 5.0 \\
\hline
\end{tabular}

Final concentration of the analyte was found to be below the DL. ND - Not Detectable

\subsubsection{Laboratory Control Samples}

Results from the Laboratory Control Sample (LCS) are given in Table 3-14. All LCS recoveries met the vendor laboratory acceptance. The surrogate recoveries were also within the acceptance limits for the VOA analysis. Laboratory Control Samples are clean aqueous solutions analyzed to assure integrity of the analytical technique exclusive of matrix effects.

Table 3-14 VOA and Phenol Laboratory Control Samples

\begin{tabular}{|c|c|c|c|c|c|c|c|c|}
\hline Analyte & \multicolumn{3}{|c|}{$\begin{array}{c}\text { Laboratory Control } \\
(\mu \mathrm{g} / \mathrm{L})\end{array}$} & \multicolumn{2}{|c|}{ Recovery } & Surrogate & $\begin{array}{l}\text { Surrogate } \\
\text { Recovery }\end{array}$ & RPD \\
\hline- & True & \multicolumn{2}{|c|}{ Measured } & \multicolumn{2}{|c|}{$\%$} & $(\mu \mathrm{g} / \mathrm{L})$ & $\%$ & $\%$ \\
\hline Benzene & 50.0 & \multicolumn{2}{|c|}{44.1} & \multicolumn{2}{|c|}{88.1} & -- & -- & -- \\
\hline Phenol & 50.0 & 51.7 & 49.0 & 103 & 98 & - & - & 5.36 \\
\hline$* * 1,2$-Dichloroethane-d4 & 50.0 & \multicolumn{2}{|c|}{--} & \multicolumn{2}{|c|}{--} & 51.8 & 104 & -- \\
\hline$* *$ Bromofluorobenzene & 50.0 & \multicolumn{2}{|c|}{-} & \multicolumn{2}{|c|}{--} & 49.5 & 99 & - \\
\hline$* *$ Toluene-d8 & 50.0 & \multicolumn{2}{|c|}{--} & \multicolumn{2}{|c|}{-} & 49.0 & 98 & - \\
\hline
\end{tabular}

- Indicates a location in the table for which an entry would not be appropriate.

** - Surrogates added to VOA analysis 


\subsubsection{Matrix Spikes}

The result from VOA analysis of the matrix spike (MS) and matrix spike duplicate (MSD) is given in Table 3-15. These results show that the percent recoveries (\%R) obtained from the spike analyses met the recommended quality control acceptance criteria for percent recoveries. The surrogate recoveries also were within the acceptance limits. Note that the toluene-d8 surrogate could also be considered a spike and as such would have a relative percent difference of $1.3 \%$. The matrix spike is not applicable to the phenol method.

Table 3-15 VOA Matrix Spike Results

\begin{tabular}{|c|c|c|c|c|c|c|c|}
\hline \multirow{2}{*}{ Analyte } & \multicolumn{2}{|c|}{$\begin{array}{c}\text { Initial Concentrations } \\
(\mu \mathrm{g} / \mathrm{L})\end{array}$} & \multicolumn{2}{|c|}{$\begin{array}{c}\text { Spiked Sample } \\
(\mu \mathrm{g} / \mathrm{L})\end{array}$} & \multicolumn{2}{|c|}{ Recovery (\%) } & \multirow{2}{*}{ RPD (\%) } \\
\hline & $\begin{array}{c}\text { GEL ID } \\
284341001\end{array}$ & $\begin{array}{l}\text { Spike } \\
\text { Added }\end{array}$ & Spike & $\begin{array}{c}\text { Spike } \\
\text { Duplicate }\end{array}$ & Spike & $\begin{array}{c}\text { Spike } \\
\text { Duplicate }\end{array}$ & \\
\hline Benzene & UND & 50.0 & 55 & 52.7 & 110 & 105 & 4.22 \\
\hline$* * 1,2$-Dichloroethane-d4 & - & 50.0 & 49 & 47.8 & 98 & 95.7 & - \\
\hline$* *$ Bromofluorobenzene & - & 50.0 & 48.7 & 47.3 & 97.4 & 94.6 & - \\
\hline$* *$ Toluene-d8 & - & 50.0 & 47.9 & 47.3 & 95.9 & 94.6 & - \\
\hline
\end{tabular}

\subsubsection{Calibration Information}

- All initial calibration requirements have been met for this sample delivery group (SDG).

- All Contract Required Detection Limit standard(s) met the referenced advisory control limits.

- All interference check samples associated with this SDG met the established acceptance criteria.

- All continuing calibration blanks bracketing this batch met the established acceptance criteria.

- All continuing calibration verifications bracketing this SDG met the acceptance criteria.

\subsection{Comparison with Prior TCLP Leachate Results}

The initial sampling and analysis in support of vault classification for Saltstone was performed on Saltstone samples prepared from Tank 41H sample collected on August 25, 2003. ${ }^{(9)}$ More recently, quarterly TCLP analysis of Saltstone prepared from Tank $50 \mathrm{H}$ has been performed for the RCRA metals potentially present in the feed solution for the Saltstone Processing Facility. Table 4-1 compares the current TCLP results for the RCRA metals with the Tank 41H sample results ${ }^{(9)}$, the fourth quarter of 2010 TCLP results ${ }^{(10)}$, and the first quarter of 2011 results ${ }^{(11)}$. 
Table 4-1 Comparison of Current 2011 RCRA TCLP Results with Past Results

\begin{tabular}{|c|c|c|c|c|}
\hline- & $\begin{array}{c}\text { Average Sample } \\
\text { Results (mg/L) } \\
\text { (9) }\end{array}$ & $\begin{array}{c}\text { Sample } \\
\text { Results } \\
(\mathbf{m g} / \mathbf{L})(10)\end{array}$ & $\begin{array}{c}\text { Sample } \\
\text { Results } \\
(\mathbf{m g} / \mathbf{L})(11)\end{array}$ & $\begin{array}{l}\text { Current } \\
\text { Sample } \\
\text { Results } \\
(\mathrm{mg} / \mathrm{L}) \\
\end{array}$ \\
\hline SRS ID & $\begin{array}{c}\text { 41-TR1 to } 41- \\
\text { TR3 }\end{array}$ & 4Q10 & $1 Q 11$ & $2 Q 11$ \\
\hline $\begin{array}{l}\text { B\&W } \\
\text { ID }\end{array}$ & $\begin{array}{c}0310002-17 \text { to } \\
0310002-19\end{array}$ & $\begin{array}{l}\text { 1101017- } \\
\text { 01A }\end{array}$ & 1103011-01A & $\begin{array}{c}1105017- \\
01 A\end{array}$ \\
\hline As & ${ }^{\mathrm{B}}(1.8 \pm 0.5) \mathrm{E}-02$ & $1.16 \mathrm{E}-02$ & 6.97E-02 & $1.34 \mathrm{E}-02$ \\
\hline $\mathbf{B a}$ & $(1.28 \pm 0.22) \mathrm{E}-01$ & $2.58 \mathrm{E}-01$ & ${ }^{\mathrm{N}} 6.55 \mathrm{E}-02$ & 2.34E-01 \\
\hline Cd & ${ }^{\mathrm{B}}(2.4 \pm 0.67) \mathrm{E}-03$ & ${ }^{\mathrm{B}} 2.80 \mathrm{E}-04$ & ${ }^{\mathrm{B}} 1.0 \mathrm{E}-03$ & ${ }^{\mathrm{B}} 3.2 \mathrm{E}-04$ \\
\hline $\mathrm{Cr}$ & ${ }^{\mathrm{B}}(2.72 \pm 0.04) \mathrm{E}-02$ & ${ }^{B} 7.20 E-03$ & 1.97E-02 & $1.83 \mathrm{E}-02$ \\
\hline $\mathbf{P b}$ & $<2.8 \mathrm{E}-02$ & ${ }^{\mathrm{B}} 5.30 \mathrm{E}-03$ & $\mathrm{~N}^{*} 5.9 \mathrm{E}-03$ & ${ }^{\mathrm{B}} 2.7 \mathrm{E}-03$ \\
\hline Hg & ${ }^{\mathrm{YB}}(5 \pm 6) \mathrm{E}-04$ & $\mathrm{~N}_{3.04 \mathrm{E}-03}$ & ${ }^{\mathrm{E}} 9.0 \mathrm{E}-03$ & $1.86 \mathrm{E}-02$ \\
\hline $\mathrm{Se}$ & ${ }^{\mathrm{B}}(1.56 \pm 0.06) \mathrm{E}-01$ & ${ }^{\mathrm{E}} 1.25 \mathrm{E}-01$ & ${ }^{\mathrm{E}} 1.39 \mathrm{E}-01$ & ${ }^{\mathrm{E}} 1.59 \mathrm{E}-01$ \\
\hline Ag & $<5.4 \mathrm{E}-03$ & $\mathrm{~N}^{*}<6.00 \mathrm{E}-05$ & $\mathrm{BN}^{*} 2.7 \mathrm{E}-04$ & ${ }^{\mathrm{B}} 1.4 \mathrm{E}-04$ \\
\hline $\mathbf{S b}$ & $<2.8 \mathrm{E}-02$ & ${ }^{\mathrm{B}} 1.90 \mathrm{E}-03$ & ${ }^{\mathrm{B}} 4.5 \mathrm{E}-03$ & ${ }^{\mathrm{B}} 3.0 \mathrm{E}-03$ \\
\hline $\mathbf{B e}$ & $1.10 \mathrm{E}-03$ & $<1.60 \mathrm{E}-04$ & $<1.6 \mathrm{E}-04$ & $<1.6 \mathrm{E}-04$ \\
\hline $\mathbf{N i}$ & $<6.9 \mathrm{E}-03$ & $\mathrm{~B}_{5.10 \mathrm{E}-03}$ & ${ }^{\mathrm{B}} 4.8 \mathrm{E}-03$ & ${ }^{\mathrm{B}} 3.5 \mathrm{E}-03$ \\
\hline $\mathbf{T I}$ & NM & $<2.10 \mathrm{E}-04$ & ${ }^{\mathrm{B}} 2.8 \mathrm{E}-04$ & ${ }^{\mathrm{B}} 2.6 \mathrm{E}-04$ \\
\hline
\end{tabular}

- Indicates a location in the table for which an entry would not be appropriate.

${ }^{B}$ Analyte is present at a concentration above the DL but less than the QL.

${ }^{\mathrm{N}}$ Associated Matrix Spike is outside percent recovery quality control criteria.

* Associated Duplicate is outside relative percent difference quality control criteria

${ }^{\mathrm{E}}$ Associated Serial Dilution is outside percent difference quality control criteria.

NM Not measured.

The last three quarters of TCLP leachate results do not show much difference between any of the RCRA metals except for mercury which has been increasing but not significantly with respect to the toxicity limit of $0.2 \mathrm{mg} / \mathrm{L}$. The difference between the initial vault classification average result and the current result is also good considering that the earlier values are based on method 6010 (inductively coupled plasma- emission spectrometer) compared to method 6020 (ICP-MS) which have different detection limits.

A comparison of the TCLP leachate results for the other metals from section 3.2 is displayed in Table 4-2. The results are generally consistent with each other and similar to that observed for the RCRA metals comparison. 
Table 4-2 Comparison of Current Other Metals TCLP Results with Past Results

\begin{tabular}{||c||c||c||}
\hline \hline \multicolumn{1}{|c||}{} & $\begin{array}{c}\text { Average Sample Results } \\
(\mathbf{m g} / \mathbf{L})(9)\end{array}$ & $\begin{array}{c}\text { Average Sample Results } \\
(\mathbf{m g} / \mathbf{L})\end{array}$ \\
\hline Year & $\mathbf{2 0 0 3}$ & $\mathbf{2 0 1 1}$ \\
\hline SRS ID & 41-TR1 to 41-TR3 & 11114-SS-Vault1 to -Vault3 \\
\hline B\&W ID & $\mathbf{0 3 1 0 0 0 2 - 1 7 \text { to 0310002-19 }}$ & $\mathbf{1 1 0 8 0 1 0 - 0 1 ~ t o ~ 1 1 0 8 0 1 0 - 0 3}$ \\
\hline \hline Aluminum & ${ }^{\mathrm{BN}} 0.40 \pm 0.31$ & $\mathrm{E}_{1.86} \pm 0.31$ \\
\hline Boron & $0.46 \pm 0.077$ & $0.75 \pm 0.06$ \\
\hline Cobalt & $<2.6 \mathrm{E}-03$ & $<0.00012$ \\
\hline Copper & $<5.9 \mathrm{E}-03$ & ${ }^{\mathrm{B}} 0.022 \pm 0.001$ \\
\hline Iron & $\mathrm{BN}^{\mathrm{BN}} 0.071 \pm 0.027$ & $0.23 \pm 0.05$ \\
\hline Lithium & $0.75 \pm 0.032$ & $0.85 \pm 0.02$ \\
\hline Manganese & ${ }^{\mathrm{B}}(6.5 \pm 5.4) \mathrm{E}-03$ & $(2.2 \pm 0.7) \mathrm{E}-03$ \\
\hline Molybdenum & $0.47 \pm 0.024$ & $0.50 \pm 0.02$ \\
\hline Strontium & $0.96 \pm 0.054$ & $0.34 \pm 0.02$ \\
\hline Zinc & 0.052 & $<0.046$ \\
\hline
\end{tabular}

- Indicates a location in the table for which an entry would not be appropriate.

${ }^{B}$ Analyte is present at a concentration above the DL but less than the QL.

${ }^{\mathrm{N}}$ Associated Matrix Spike is outside percent recovery quality control criteria.

${ }^{\mathrm{E}}$ Associated Serial Dilution is outside percent difference quality control criteria.

The radionuclides in the TCLP leachate from the Tank41H saltstone samples and the current vault classification samples are shown in Table 4-3. The average values are shown plus or minus one standard deviation for those results that have more than one measured value available.

Table 4-3 Comparison of Current Radionuclide TCLP Results with Past Results

\begin{tabular}{|c|c|c|c|}
\hline Year & - & 2003 & 2011 \\
\hline SRS ID & - & 41-TR1 to TR3 & $\begin{array}{c}\text { 11114-SS-Vault1 } \\
\text { to Vault3 }\end{array}$ \\
\hline $\begin{array}{c}\text { BW-TSG } \\
\text { ID }\end{array}$ & - & $\begin{array}{c}0310002-17 \text { to } \\
0310002-19 \\
\end{array}$ & \begin{tabular}{|c|}
$1108010-01$ to \\
$1108010-03$ \\
\end{tabular} \\
\hline $\begin{array}{l}\text { GEL Lab } \\
\text { ID }\end{array}$ & - & 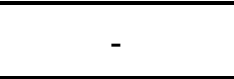 & $\begin{array}{c}284341004 \text { to } \\
284341006\end{array}$ \\
\hline Analyte & $\begin{array}{c}\text { MCL } \\
\text { (pCi/L) } \\
\end{array}$ & $\begin{array}{c}\text { Average (pCi/L) } \\
\text { (9) }\end{array}$ & Average $(\mathrm{pCi} / \mathrm{L})$ \\
\hline Gross $\alpha$ & 15 & $(1.8 \pm 1.2) \mathrm{E}+04$ & $<1.7 \mathrm{E}+03$ \\
\hline Gross $\beta$ & - & $(6.2 \pm 0.34) \mathrm{E}+08$ & $(1.8 \pm 0.1) \mathrm{E}+07$ \\
\hline${ }^{3} \mathbf{H}$ & - & $1.70 \mathrm{E}+04$ & $(1.2 \pm 0.5) \mathrm{E}+03$ \\
\hline${ }^{60} \mathrm{Co}$ & - & $<6.2 \mathrm{E}+03$ & $<65$ \\
\hline${ }^{90} \mathrm{Sr}$ & - & $(8.1 \pm 3.2) \mathrm{E}+05$ & $(9.7 \pm 4.3) \mathrm{E}+04$ \\
\hline${ }^{99} \mathrm{Tc}$ & - & $(8.4 \pm 1.6) \mathrm{E}+04$ & $(5.1 \pm 0.7) \mathrm{E}+04$ \\
\hline${ }^{106} \mathrm{Ru}$ & - & $<1.3 \mathrm{E}+06$ & $<1.5 \mathrm{E}+04$ \\
\hline${ }^{106} \mathrm{Rh}$ & - & $<9.5 \mathrm{E}+05$ & $<1.1 \mathrm{E}+04$ \\
\hline${ }^{125} \mathrm{Sb}$ & - & $<6.6 \mathrm{E}+05$ & $<7.7 \mathrm{E}+03$ \\
\hline
\end{tabular}




\begin{tabular}{|c|c|c|c|}
\hline Year & - & 2003 & 2011 \\
\hline SRS ID & - & 41-TR1 to TR3 & $\begin{array}{c}\text { 11114-SS-Vault1 } \\
\text { to Vault3 }\end{array}$ \\
\hline $\begin{array}{c}\text { BW-TSG } \\
\text { ID } \\
\end{array}$ & - & $\begin{array}{c}0310002-17 \text { to } \\
0310002-19\end{array}$ & $\begin{array}{c}1108010-01 \text { to } \\
1108010-03 \\
\end{array}$ \\
\hline $\begin{array}{l}\text { GEL Lab } \\
\text { ID }\end{array}$ & - & ( & $\begin{array}{c}284341004 \text { to } \\
284341006\end{array}$ \\
\hline Analyte & $\begin{array}{c}\text { MCL } \\
(\mathrm{pCi} / \mathbf{L})\end{array}$ & $\begin{array}{c}\text { Average (pCi/L) } \\
(9)\end{array}$ & Average (pCi/L) \\
\hline${ }^{137} \mathrm{Cs}$ & - & $(7.2 \pm 0.46) \mathrm{E}+08$ & $(1.8 \pm 0.2) \mathrm{E}+07$ \\
\hline${ }^{137 m b} \mathbf{B a}$ & - & $(6.7 \pm 0.43) \mathrm{E}+08$ & $(1.7 \pm 0.1) \mathrm{E}+07$ \\
\hline${ }^{147} \mathrm{Pm}$ & - & $<1.9 \mathrm{E}+05$ & $<1.2 \mathrm{E}+02$ \\
\hline${ }^{154} \mathrm{Eu}$ & - & $<2.1 \mathrm{E}+04$ & $<3.1 \mathrm{E}+02$ \\
\hline${ }^{226} \mathbf{R a}$ & 5 & $<4.2 \mathrm{E}+04$ & $<4.4 \mathrm{E}+04$ \\
\hline${ }^{228} \mathbf{R a}$ & 5 & $<3.5 \mathrm{E}+04$ & $<3.6 \mathrm{E}+03$ \\
\hline${ }^{238} \mathrm{Pu}$ & - & $(7.3 \pm 5.4) \mathrm{E}+03$ & $<12$ \\
\hline${ }^{239 / 240} \mathrm{Pu}$ & - & $(3.1 \pm 2.6) \mathrm{E}+02$ & $<8.3$ \\
\hline${ }^{241} \mathrm{Pu}$ & - & $(3.4 \pm 2.7) \mathrm{E}+03$ & $<8.0 \mathrm{E}+02$ \\
\hline${ }^{241} \mathrm{Am}$ & & $(4.1 \pm 2.9) \mathrm{E}+02$ & $<11$ \\
\hline${ }^{242} \mathrm{Cm}$ & - & $6.5 \pm 4.9$ & $<9.2$ \\
\hline${ }^{243 / 244} \mathrm{Cm}$ & - & $(6.6 \pm 4.8) \mathrm{E}+03$ & $<4.8$ \\
\hline
\end{tabular}

- Indicates a location in the table for which an entry would not be appropriate.

The primary differences between the 2004 average results and the 2011 average results are that the primary gamma source $\left({ }^{137} \mathrm{Cs}\right)$ is a factor of 40 less in the new result, the ${ }^{90} \mathrm{Sr}$ is a factor of 8 less in the new result and the transuranic radionuclides are at least one order of magnitude less in the new results. The one measured radionuclide that is approximately the same (less than factor of two different) is ${ }^{99} \mathrm{Tc}$. These results are consistent with the current vault classification samples primarily containing salt solution that has passed through the ARP/MCU process which is designed to reduce the concentrations of cesium, strontium and the actinides but not the concentration of technetium.

\subsection{Conclusions}

Savannah River National Laboratory (SRNL) was asked to prepare saltstone from samples of Tank 50H obtained by SRNL on April 5, 2011 (Tank 50H sampling occurred on April 4, 2011) during 2QCY11 to determine the non-hazardous nature of the grout and for additional vault classification analyses. The samples were cured and shipped to Babcock \& Wilcox Technical Services Group-Radioisotope and Analytical Chemistry Laboratory (B\&W TSG-RACL) to perform the Toxic Characteristic Leaching Procedure (TCLP) ${ }^{(1)}$ and subsequent extract analysis on saltstone samples for the analytes required for the quarterly analysis saltstone sample. In addition to the eight toxic metals - arsenic, barium, cadmium, chromium, mercury, lead, selenium and silver-analytes included the underlying hazardous constituents (UHC) antimony, beryllium, nickel, and thallium which could not be eliminated from analysis by process knowledge. Additional inorganic species determined by B\&W TSG-RACL include aluminum, boron, chloride, cobalt, copper, fluoride, iron, lithium, manganese, molybdenum, nitrate/nitrite as Nitrogen, strontium, sulfate, uranium, and zinc and the following radionuclides: gross alpha, 
gross beta/gamma, ${ }^{3} \mathrm{H},{ }^{60} \mathrm{Co},{ }^{90} \mathrm{Sr},{ }^{99} \mathrm{Tc},{ }^{106} \mathrm{Ru},{ }^{106} \mathrm{Rh},{ }^{125} \mathrm{Sb},{ }^{137} \mathrm{Cs},{ }^{137 \mathrm{~m}} \mathrm{Ba},{ }^{154} \mathrm{Eu},{ }^{238} \mathrm{Pu},{ }^{239 / 240} \mathrm{Pu}$, ${ }^{241} \mathrm{Pu},{ }^{241} \mathrm{Am},{ }^{242} \mathrm{Cm}$, and ${ }^{243 / 244} \mathrm{Cm}$. B\&W TSG-RACL provided subsamples to GEL Laboratories, LLC for analysis for the VOCs benzene, toluene, and 1-butanol. GEL also determines phenol (total) and the following radionuclides: ${ }^{147} \mathrm{Pm},{ }^{226} \mathrm{Ra}$ and ${ }^{228} \mathrm{Ra}$.

Preparation of the 2QCY11 saltstone samples for the quarterly analysis and for vault classification purposes and the subsequent TCLP analyses of these samples showed that:

- The saltstone waste form disposed of in the Saltstone Disposal Facility in 2QCY11 was not characteristically hazardous for toxicity.

- The concentrations of the eight RCRA metals and UHCs identified as possible in the saltstone waste form were present at levels below the UTS.

- Most of the inorganic species measured in the leachate do not exceed the MCL, SMCL or TW limits.

- The inorganic waste species that exceeded the MCL by more than a factor of 10 were nitrate, nitrite and the sum of nitrate and nitrite.

- Analyses met all quality assurance specifications of US EPA SW-846.

- The organic species (benzene, toluene, 1-butanol, phenol) were either not detected or were less than reportable for the vault classification samples.

- The gross alpha and radium isotopes could not be determined to the MCL because of the elevated background which raised the detection limits.

- Most of the beta/gamma activity was from ${ }^{137} \mathrm{Cs}$ and its daughter ${ }^{137 \mathrm{~m}} \mathrm{Ba}$.

- The concentration of ${ }^{137} \mathrm{Cs}$ and ${ }^{90} \mathrm{Sr}$ were present in the leachate at concentrations $1 / 40^{\text {th }}$ and $1 / 8^{\text {th }}$ respectively than in the 2003 vault classification samples.

The saltstone waste form placed in the Saltstone Disposal Facility in 2QCY11 met the SCHWMR R.61-79.261.24(b) RCRA metals requirements for a nonhazardous waste form. The TCLP leachate concentrations for nitrate, nitrite and the sum of nitrate and nitrite were greater than $10 \mathrm{x}$ the MCLs in SCDHEC Regulations R.61-107.19, Part I A, which confirms the Saltstone Disposal Facility classification as a Class 3 Landfill. The saltstone waste form placed in the Saltstone Disposal Facility in 2QCY11 met the R.61-79.268.48(a) non wastewater treatment standards. 
SRNL-STI-2011-00561

Revision 0

\subsection{References}

1. Toxicity Characteristic Leaching Procedure. Environmental Protection Agency : s.n. SW-846, Procedure 1311.

2. Price, M. R. Waste Compliance Program for Liquid Waste Transfers from H_Canyon to 241H Tank Farm. s.l. : Savannah River Site. X-WCP-G-00008 Revision 14.

3. Wiggins, A. W. F/H Effluent Treatment Project Waste Concentrate Regular Waste Compliance Plan. s.l. : Savannah River Site. X-WCP-H-00002 Revision 12.

4. Liner, K. R. Sampling and Analysis Plan for the Z-Area Industrial Solid Waste Landfill Disposal Facility During Interim Salt Waste Processing (U). s.l. : Savannah River Site, 2005. EXH-WPG-2005-00039.

5. —. "Saltstone Grout Sampling (U)". s.l. : Savannah River Site, 2004. ESH-EPG-2004-00318.

6. Eibling, R. E. Results for the Second Quarter 2011 Tank 50 WAC Slurry Sample: Chemical and Radionuclide Contaminant Results. Savannah River National Laboratory : s.n., August 2011. SRNL-STI-2011-00443 Revision 0.

7. Reigel, M. M. Saltstone TCLP. s.l. : Savannah River National Laboratory. SRNL-NB-200900076.

8. Eibling, R. E. Data Package from Vendor for 2QCY11 Vault Classification Analysis. s.l. : Savannah River National Laboratory, September 8, 2011. SRNL-L3100-2011-00185 Revision 0.

9. Ferrara, D., Cozzi, A., Langton, C., Clark, J. Tank 41H Saltstone Regulatory Analyses. Savannah River Site: Westinghouse Savannah River Company, February 2004. WSRC-TR2004-00051, Rev. 0.

10. Reigel, M. M. Saltstone 4QCY10 TCLP Results. Savannah River National Laboratory : s.n., March 2011. SRNL-STI-2011-00127, Rev 0..

11. - Saltstone 1QCY11 TCLP Results. Savannah River National Laboratory : s.n., May 2011. SRNL-STI-2011-00262. 
SRNL-STI-2011-00561

Revision 0

Appendix South Carolina Department of Health and Environmental Control Forms 


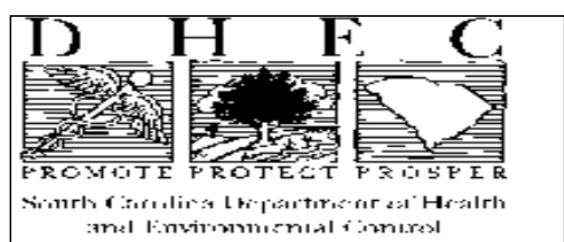

ype Data: Company Name: Subject/Project:

Industrial RCRA - TCLP Metals

Date: $09 / 27 / 11$

Savannah River Remediation

Saltstone Vault Classification April 2011

(Subtitle C, Subtitle D or Class Three Landfills only.)

(Consult the Department for any Radiation / Chemical Mixed Wastes,

Facility Sample ID \#

Laboratory Sample ID \#

Laboratory Name

SC Laboratory Certification \#

Subcontracted Laboratory Certification \#

Subcontracted Laboratory Name

Laboratory Receipt Information (Chain of Custody Must be Attached)

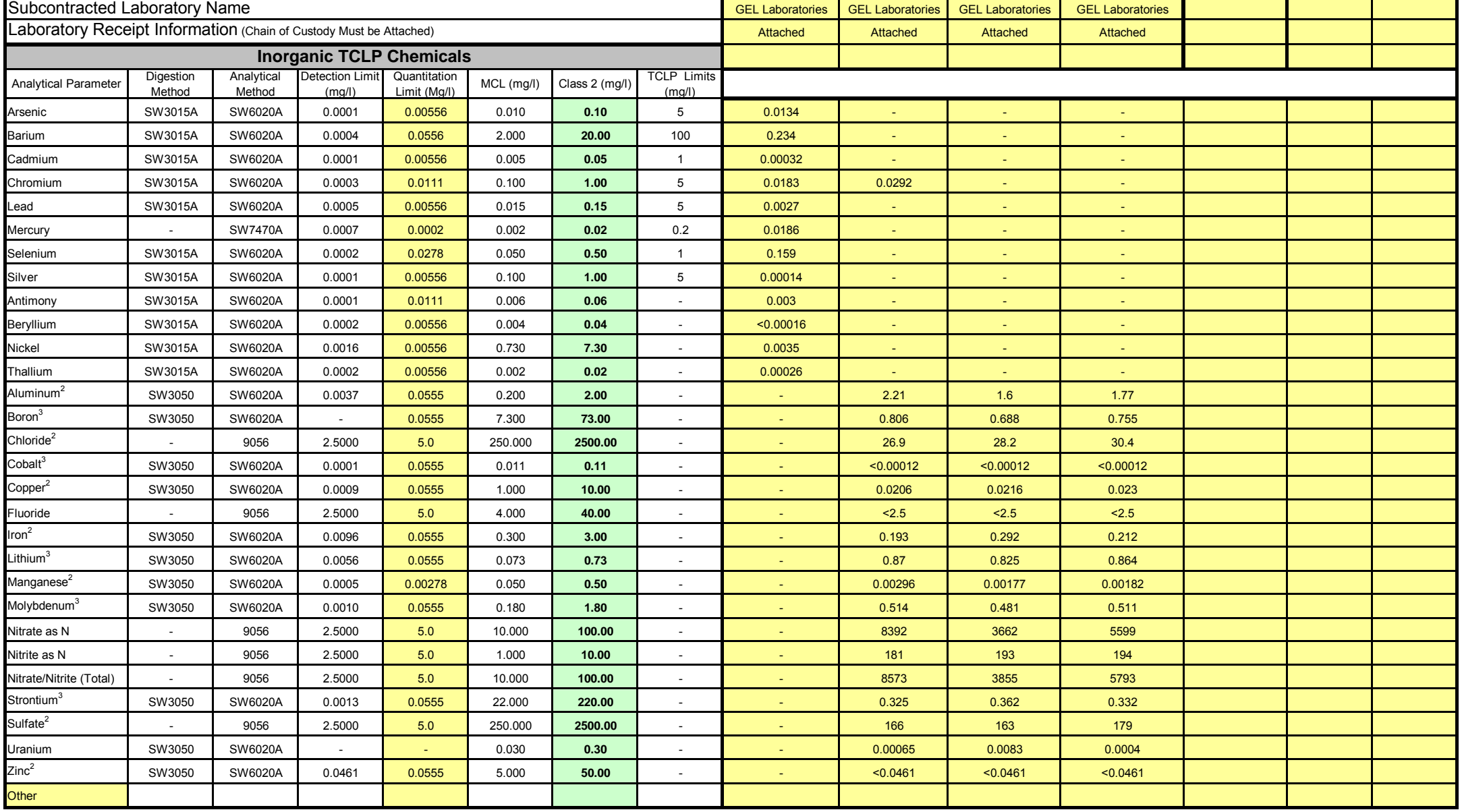




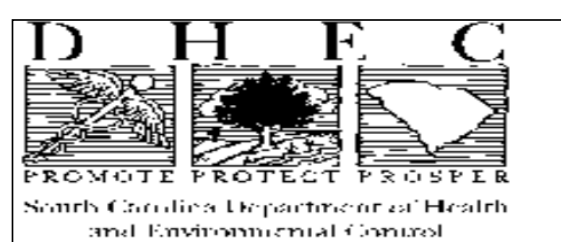

Type Data: Company Name: Subject/Project:

Industrial RCRA - TCLP Metals

Date: $09 / 27 / 11$

\section{Savannah River Remediation}

Saltstone Vault Classification April 2011

(Subtitle C, Subtitle D or Class Three Landfills only.)

(Consult the Department for any Radiation / Chemical Mixed Wastes.

Facility Sample ID \#

Laboratory Sample ID \#

Laboratory Name

SC Laboratory Certification \#

Subcontracted Laboratory Certification \#

Subcontracted Laboratory Name

Laboratory Receipt Information (Chain of Custody Must be Attached)

\begin{tabular}{|c|c|c|}
\hline & Inorganic TCLP Chemicals
\end{tabular}

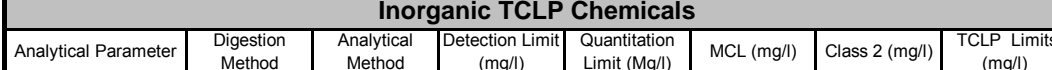

\section{Quality Assurance (for above samples)}

TCLP Bottle Extraction \#

TCLP Extraction Blank

Digestion Batch \#

Digestion Blank

Laboratory Control sample

Matrix Spike (MS)

Matrix Spike Duplicate (MSD)

Unspiked Duplicate (If Used)

Analysis Batch Number

LCS Recovery

MS \& MSD

\begin{tabular}{|c|c|c|c|c|c|c|}
\hline \multicolumn{7}{|c|}{ Results in Milligrams per Liter } \\
\hline \multicolumn{4}{|c|}{ Waste Stream 1} & \multirow{2}{*}{\begin{tabular}{|l|} 
Waste Stream 2 \\
Sample 1 Date 1 \\
\end{tabular}} & \multicolumn{2}{|c|}{ Waste Stream 3} \\
\hline 4/5/2011 & 4/5/2011 & 4/5/2011 & 4/5/2011 & & $\begin{array}{c}\text { Sample } 1 \text { Date } \\
1\end{array}$ & $\begin{array}{c}\text { Sample 2 Date } \\
2\end{array}$ \\
\hline 1113-SS-TCLP-2Q1 & 11114-SS-VAULT-1 & 11114-SS-VAULT-2 & 11114-SS-VAULT-3 & & & \\
\hline $1105017-01$ & 1108010-01 & $1108010-02$ & 1108010-03 & & & \\
\hline B\&W TSG-RACL & B\&W TSG-RACL & B\&W TSG-RACL & B\&W TSG-RACL & & & \\
\hline$z$ & $z$ & $z$ & $\mathrm{z}$ & & & \\
\hline 10120001/10120002 & 10120001/10120002 & $10120001 / 10120002$ & 10120001/10120002 & & & \\
\hline GEL Laboratories & GEL Laboratories & GEL Laboratories & GEL Laboratories & & & \\
\hline Attached & Attached & Attached & Attached & & & \\
\hline & & & & & & \\
\hline & & & & & & \\
\hline B1E3101 & B1H1105 & B1H1105 & B1H1105 & & & \\
\hline B1E3101-BLK1 & B1H1105-BLK1 & B1H1105-BLK1 & B1H1105-BLK1 & & & \\
\hline B1F0101 & B1H2202 & B1H2202 & B1H2202 & & & \\
\hline B1F0101-BLK1 & B1H2202-BLK1 & B1H2202-BLK1 & B1H2202-BLK1 & & & \\
\hline B1F0101-SRM1 & B1F2202-SRM1 & B1F2202-SRM1 & B1F2202-SRM1 & & & \\
\hline B1F0101-MS1 & B1H1105-MS1 & B1H1105-MS1 & B1H1105-MS1 & & & \\
\hline B1F0101-MSD1 & B1H1105-MSD1 & B1H1105-MSD1 & B1H1105-MSD1 & & & \\
\hline- & - & - & - & & & \\
\hline B1F0101 & B1H2202 & $\mathrm{B} 1 \mathrm{H} 2202$ & $\mathrm{~B} 1 \mathrm{H} 2202$ & & & \\
\hline Acceptable & Acceptable & Acceptable & Acceptable & & & \\
\hline Acceptable & Acceptable, ex Zn & Acceptable, ex Zn & Acceptable, ex Zn & & & \\
\hline
\end{tabular}

1. Subcontracted Laboratory Used for this parameter

2. The MCL for these elements are Secondary Maximum Contaminant Levels.

3. The MCL for these species are TW values.

$Z$ DOECAP, NUPIC and NELAP requirements 


\section{H E C 整量 and Environmental Control
LABORATORY: B\&W Technical Services Group - RACL

METHOD NAME: SW846-6020A, SW846-7470A, SW846-9056, TCLP Metals, Other Metals, Anions

SUBJECT: $\quad$ QA- Blk, Laboratory Control Sample (LCS), Matrix Spike (MS), Matrix Spike Duplicate (MSD)

Reference: Industrial RCRA - TCLP Metals

Instrument: $\quad$ X-7 Series ICP-MS, Leman PC 200 II, Dionex DX-100

\begin{tabular}{|c|c|c|c|c|c|c|c|c|c|c|c|c|c|c|c|c|c|}
\hline \multirow[b]{2}{*}{ Analytes } & \multicolumn{8}{|c|}{ Analyte Concentrations, $\mathrm{Mg} / \mathrm{I}$} & \multicolumn{8}{|c|}{ Recovery Percent } & \multirow[t]{2}{*}{ Flags } \\
\hline & RDL & MDL & Blank & LCS & LCSD & MS & MSD & Other & LCS & LCSD & MS & MSD & Ave MS/MSD & REC Limits & $\%$ RPD & RPD Limits & \\
\hline Antimony & 0.0111 & 0.00013 & 0.00023 & 0.311 & - & 0.937 & 0.926 & & 95 & - & 93 & 92 & 92 & $75-125$ & 1 & $0-20$ & \\
\hline Arsenic & 0.00556 & 0.0001 & 0.0018 & 0.704 & - & 0.528 & 0.569 & & 98 & - & 103 & 111 & 107 & $75-125$ & 7 & $0-20$ & \\
\hline Barium & 0.0556 & 0.00044 & 0.0031 & 0.459 & - & 2.687 & 2.703 & & 99 & - & 98 & 99 & 98 & $75-125$ & 1 & $0-20$ & \\
\hline Beryllium & 0.00556 & 0.00016 & $<0.00016$ & 0.116 & - & 0.205 & 0.203 & & 85 & - & 82 & 81 & 82 & $75-125$ & 1 & $0-20$ & \\
\hline Cadmium & 0.0056 & 0.00011 & $<0.00011$ & 0.465 & - & 0.218 & 0.216 & & 98 & - & 87 & 86 & 86 & $75-125$ & 1 & $0-20$ & \\
\hline Chromium & 0.01111 & 0.00031 & 0.00072 & 0.163 & - & 0.926 & 0.927 & & 101 & - & 91 & 91 & 91 & $75-125$ & 0 & $0-20$ & \\
\hline $\begin{array}{c}\text { Cyanide } \\
\text { (as free cyanide) }\end{array}$ & - & - & - & - & - & - & - & - & - & - & - & - & - & - & - & - & \\
\hline Fluoride & 5 & 2.5 & - & 0.87 & - & 0.86 & 0.88 & & 86.5 & - & 86 & 88 & 87 & - & 2.2 & - & \\
\hline Lead & 0.00556 & 0.00048 & 0.0061 & 0.291 & - & 0.543 & 0.543 & & 104 & - & 108 & 108 & 108 & $75-125$ & 0 & $0-20$ & \\
\hline Mercury & 0.0002 & 0.00007 & $<0.00007$ & 6.41 & - & 0.0244 & 0.0231 & & 119 & - & 116 & 90 & 103 & $75-125$ & 5.5 & $0-20$ & \\
\hline Nickel & 0.00556 & 0.0016 & 0.0056 & 0.524 & - & 0.85 & 0.848 & & 98 & - & 85 & 84 & 84 & $75-125$ & 0 & $0-20$ & \\
\hline $\begin{array}{c}\text { Nitrate } \\
\text { (as Nitrogen) }\end{array}$ & 5 & 2.5 & - & 0.98 & - & 9.56 & 9.66 & & 97.7 & - & 116 & 127 & 122 & - & 1.1 & - & \\
\hline $\begin{array}{c}\text { Nitrite } \\
\text { (as Nitrogen) }\end{array}$ & 5 & 2.5 & - & 1.02 & - & 1.22 & 1.2 & & 101.8 & - & 100 & 99 & 100 & - & 1.3 & - & \\
\hline Nitrate/Nitrite (Total) & 5 & 2.5 & - & - & - & - & - & - & - & - & - & - & - & - & - & - & \\
\hline Selenium & 0.0278 & 0.00024 & 0.0535 & 0.965 & - & 0.38 & 0.409 & & 96 & - & 88 & 100 & 94 & $75-125$ & 7 & $0-20$ & \\
\hline Silver & 0.00556 & 0.00006 & 0.0001 & 0.19 & - & 0.19 & 0.19 & & 98 & - & 76 & 76 & 76 & $75-125$ & 0 & $0-20$ & \\
\hline Thallium & 0.00556 & 0.00021 & $<0.00021$ & 0.134 & - & 0.262 & 0.263 & & 94 & - & 105 & 105 & 105 & $75-125$ & 0 & $0-20$ & \\
\hline Aluminum & 0.0555 & 0.00373 & 0.0345 & 2.46 & - & 2.56 & 2.68 & & 91 & - & 79 & 91 & 85 & $70-130$ & 4.58 & $0-20$ & \\
\hline Boron & 0.0555 & - & 0.0802 & 1.46 & - & 1.58 & 1.61 & & 92 & - & 83 & 86 & 84 & $70-130$ & 1.88 & $0-20$ & \\
\hline Cobalt & 0.0555 & 0.00012 & 0.00013 & 0.254 & - & 1.7 & 1.74 & & 92 & - & 85 & 87 & 86 & $70-130$ & 2.33 & $0-20$ & \\
\hline Copper & 0.0555 & 0.00087 & 0.0186 & 0.296 & - & 1.64 & 1.66 & & 94 & - & 81 & 82 & 82 & $70-130$ & 1.21 & $0-20$ & \\
\hline Iron & 0.0555 & 0.00962 & 0.132 & 2.19 & - & 5.38 & 5.56 & & 95 & - & 86 & 89 & 88 & $70-130$ & 3.29 & $0-20$ & \\
\hline Lithium & 0.0555 & 0.00556 & $<0.00556$ & - & - & 1.72 & 1.72 & & - & - & 86 & 86 & 86 & $70-130$ & 0 & $0-20$ & \\
\hline
\end{tabular}




\section{H E C

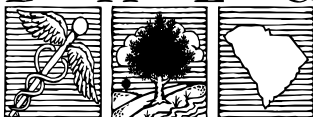 \\ PROMOTE PROTECT PROSPE \\ South Carolina Department of Healt and Environmental Control}

LABORATORY: B\&W Technical Services Group - RACL

METHOD NAME: SW846-6020A, SW846-7470A, SW846-9056, TCLP Metals, Other Metals, Anions

SUBJECT: $\quad$ QA- Blk, Laboratory Control Sample (LCS), Matrix Spike (MS), Matrix Spike Duplicate (MSD)

Reference: $\quad$ Industrial RCRA - TCLP Metals

Instrument: $\quad$ X-7 Series ICP-MS, Leman PC 200 II, Dionex DX-100

\begin{tabular}{|c|c|c|c|c|c|c|c|c|c|c|c|c|c|c|c|c|c|}
\hline \multirow[b]{2}{*}{ Analytes } & \multicolumn{8}{|c|}{ Analyte Concentrations, $\mathrm{Mg} / \mathrm{I}$} & \multicolumn{8}{|c|}{ Recovery Percent } & \multirow[t]{2}{*}{ Flags } \\
\hline & RDL & MDL & Blank & LCS & LCSD & MS & MSD & Other & LCS & LCSD & MS & MSD & Ave MS/MSD & REC Limits & $\%$ RPD & RPD Limits & \\
\hline Manganese & 0.00278 & 0.00046 & 0.00441 & 0.522 & - & 1.68 & 1.7 & & 92 & - & 84 & 85 & 84 & $70-130$ & 1.18 & $0-20$ & \\
\hline Molybdenum & 0.0555 & 0.00102 & $<0.00102$ & 0.354 & - & 2.13 & 2.18 & & 91 & - & 108 & 111 & 110 & $70-130$ & 2.32 & $0-20$ & \\
\hline Strontium & 0.0555 & 0.00125 & 0.00796 & 0.181 & - & 1.24 & 1.27 & & 90 & - & 91 & 94 & 92 & $70-130$ & 2.39 & $0-20$ & \\
\hline Uranium & - & - & 0.0026 & - & - & 0.774 & 0.792 & & - & - & 107.1 & 109.6 & 108.4 & $70-130$ & 2.3 & $0-20$ & \\
\hline Zinc & 0.0555 & 0.0461 & 0.0606 & 0.263 & - & 2.59 & 2.64 & & 92 & - & 74 & 75 & 74 & $70-130$ & 1.91 & $0-20$ & \\
\hline Chloride & 5 & 2.5 & - & 1.03 & - & 1.02 & 1.01 & & 102.7 & - & 92 & 90 & 91 & - & 1.2 & - & \\
\hline Sulfate & 5 & 2.5 & - & 0.99 & - & 1.14 & 1.16 & & 98.6 & - & 91 & 93 & 92 & - & 1.8 & - & \\
\hline \multicolumn{18}{|l|}{ Clock ID } \\
\hline & & & & & & & & & & & & & & & & & \\
\hline & & & & & & & & & & & & & & & & & \\
\hline & & & & & & & & & & & & & & & & & \\
\hline & & & & & & & & & & & & & & & & & \\
\hline
\end{tabular}

Footnotes: 


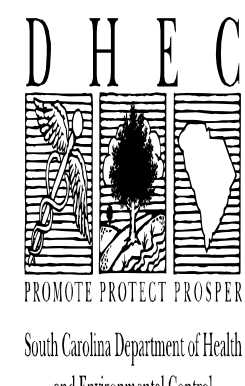

\section{Cross Reference Report for QA and Analytes}

Date: 9/28/2011

Analytical Method Reference: Lab Reference (to Facility Sample):

Subject I Project:

Facility:

SW846- 6020A/7470A(TCLP Metals)

B\&W TSG-RACL (1105017-01, 1108010-01 to -03)

Saltstone Vault Classification April 2011

Savannah River Remediation, LLC

\begin{tabular}{|c|c|c|c|c|c|c|}
\hline LAB ID \# & FACILITY SAMP ID \# & TC EXTR BATCH \# & DIGESTION BATCH \# & ANALYSIS BATCH \# & OTHER & COMMENTS \\
\hline B1E3101-BLK1 TCLP Blk & None & B1E3101 & B1F0101 & B1F0101 & - & 6020A ICPMS Metals \\
\hline B1F0101-SRM1 LCS & None & B1E3101 & B1F0101 & B1F0101 & - & 6020A ICPMS Metals \\
\hline B1F0101-MS1 & 11113-SS-TCLP-2Q11 & B1E3101 & B1F0101 & B1F0101 & - & 6020A ICPMS Metals \\
\hline B1F0101-MSD1 & 11113-SS-TCLP-2Q11 & B1E3101 & B1F0101 & B1F0101 & - & 6020A ICPMS Metals \\
\hline 1105017-01A & 11113-SS-TCLP-2Q11 & B1E3101 & B1F0101 & B1F0101 & - & 6020A ICPMS Metals \\
\hline B1E3101-BLK1 TCLP Blk & None & B1E3101 & B1F0101 & B1F0102 & - & 7470A, Hg CVAA \\
\hline B1E3101-SRM1 LCS & None & B1E3101 & B1F0101 & B1F0102 & - & 7470A, Hg CVAA \\
\hline B1E3101-MS1 & 11113-SS-TCLP-2Q11 & B1E3101 & B1F0101 & B1F0102 & - & 7470A, Hg CVAA \\
\hline B1E3101-MSD1 & 11113-SS-TCLP-2Q11 & B1E3101 & B1F0101 & B1F0102 & - & 7470A, Hg CVAA \\
\hline $1105017-01 \mathrm{~A}$ & 11113-SS-TCLP-2Q11 & B1E3101 & B1F0101 & B1F0102 & - & 7470A, Hg CVAA \\
\hline B1H1105-BLK1 TCLP Blk & None & B1H1105 & B1H2202 & B1H2202 & - & 6020A ICPMS Metals \\
\hline B1F2202-SRM1 LCS & None & B1H1105 & B1H2202 & B1H2202 & - & 6020A ICPMS Metals \\
\hline B1H1105-MS1 & 11114-SS-VAULT3 & B1H1105 & B1H2202 & B1H2202 & - & 6020A ICPMS Metals \\
\hline B1H1105-MSD1 & 11114-SS-VAULT3 & B1H1105 & B1H2202 & B1H2202 & - & 6020A ICPMS Metals \\
\hline 1108010-01-A & 11114-SS-VAULT1 & B1H1105 & B1H2202 & B1H2202 & - & 6020A ICPMS Metals \\
\hline $1108010-02-\mathrm{A}$ & 11114-SS-VAULT2 & B1H1105 & B1H2202 & B1H2202 & - & 6020A ICPMS Metals \\
\hline 1108010-03-A & 11114-SS-VAULT3 & B1H1105 & B1H2202 & B1H2202 & - & 6020A ICPMS Metals \\
\hline & & & & & & \\
\hline & & & & & & \\
\hline & & & & & & \\
\hline & & & & & & \\
\hline
\end{tabular}




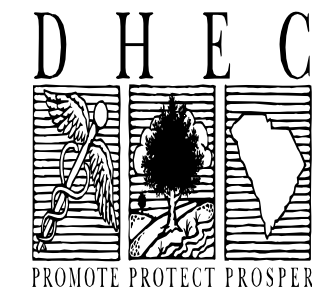

PRONOTE PROTECT PROSPER and Environmental Control

\section{Cross Reference Report for QA and Analytes}

Analytical Method Reference: Lab Reference (to Facility Sample):

Subject / Project:

Facility:
Date: 9/28/2011

SW846-9056 TCLP Anions

B\&W TSG-RACL (1108010-01 to -03)

Saltstone Vault Classification April 2011

Savannah River Remediation, LLC

\begin{tabular}{|c|c|c|c|c|c|c|}
\hline LAB ID \# & FACILITY SAMP ID \# & TC EXTR BATCH \# & DIGESTION BATCH \# & ANALYSIS BATCH \# & OTHER & COMMENTS \\
\hline B1H1105-SRM1 LCS & None & B1H1105 & B1H1105 & B1H1105 & - & 9056 IC Anions \\
\hline B1H1105-MS1 & 11114-SS-VAULT1 & B1H1105 & B1H1105 & B1H1105 & - & 9056 IC Anions \\
\hline B1H1105-MSD1 & 11114-SS-VAULT1 & B1H1105 & B1H1105 & B1H1105 & - & 9056 IC Anions \\
\hline $1108010-01$ & 11114-SS-VAULT1 & B1H1105 & B1H1105 & B1H1105 & - & 9056 IC Anions \\
\hline $1108010-02$ & 11114-SS-VAULT2 & B1H1105 & B1H1105 & B1H1105 & - & 9056 IC Anions \\
\hline $1108010-03$ & 11114-SS-VAULT3 & B1H1105 & B1H1105 & B1H1105 & - & 9056 IC Anions \\
\hline & & & & & & \\
\hline & & & & & & \\
\hline & & & & & & \\
\hline & & & & & & \\
\hline & & & & & & \\
\hline & & & & & & \\
\hline & & & & & & \\
\hline & & & & & & \\
\hline & & & & & & \\
\hline & & & & & & \\
\hline & & & & & & \\
\hline & & & & & & \\
\hline & & & & & & \\
\hline & & & & & & \\
\hline
\end{tabular}




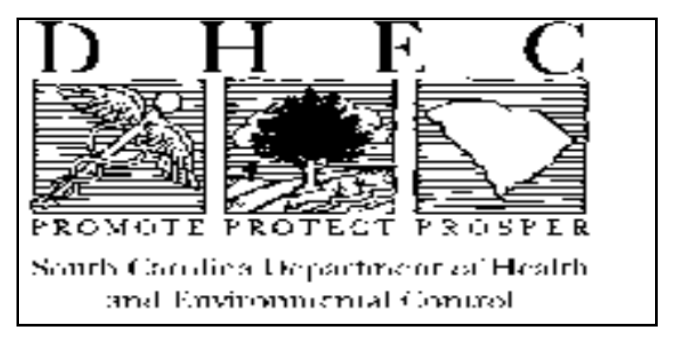

(Consult the Department for any Radiation / Chemical Mixed Wastes.)

Facility Sample ID \#

Laboratory Sample ID \#

Laboratory Name

SC Laboratory Certification \#

Subcontracted Laboratory Certification \#

Subcontracted Laboratory Name

Laboratory Receipt Information (Chain of Custody Must be Attached)

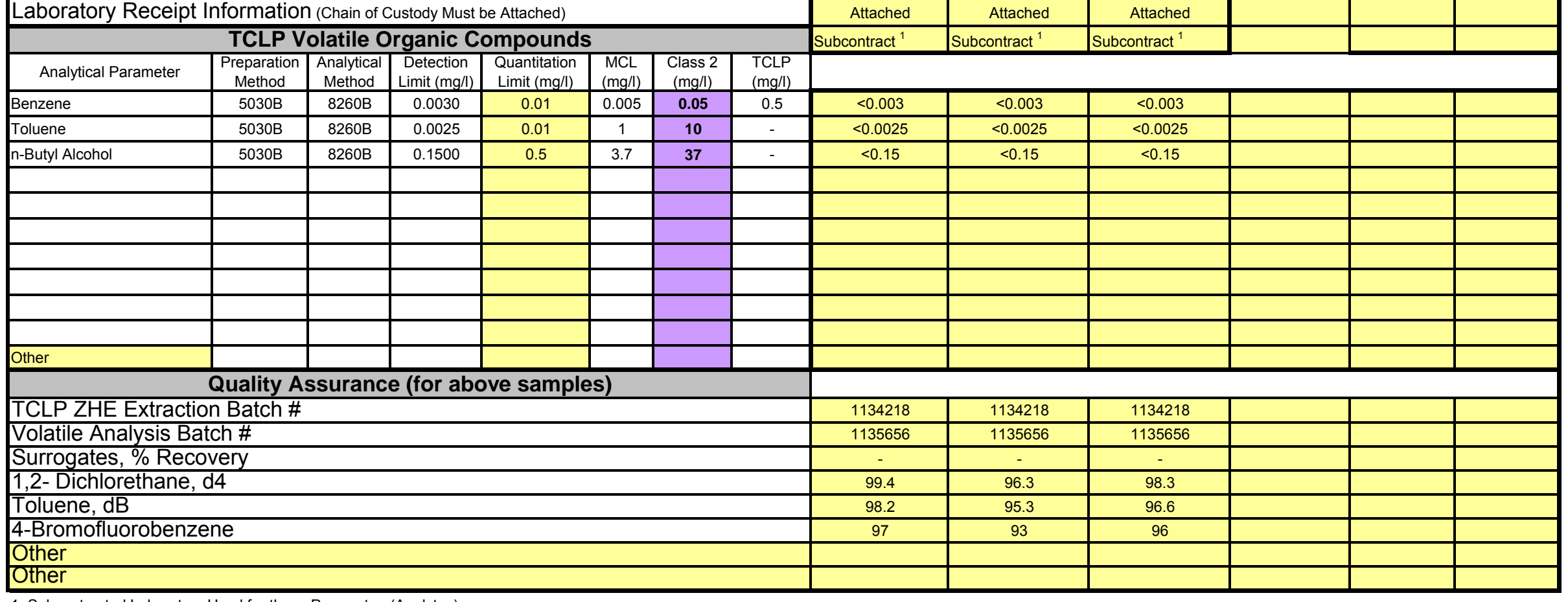

1. Subcontracted Laboratory Used for these Parameters(Analytes)

$Z$ DOECAP, NUPIC and NELAP requirements
Type Data: Industrial RCRA - TCLP Volatiles

Company Name: Savannah River Remediation

Subject/Project: Saltstone Vault Classification April 2011 


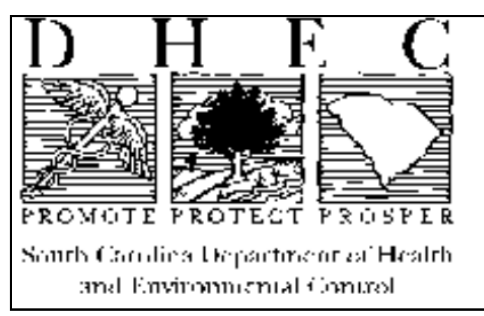

Type Data:

Company Name:

Subject/Project:

\section{Industrial RCRA - TCLP Semi-Volatiles}

Savannah River Remediation

Saltstone Vault Classification April 2011

(Subtitle C, Subtitle D or Class Three Landfills only.)

(Consult the Department for any Radiation / Chemical Mixed Wastes.)

Facility Sample ID \#

Laboratory Sample ID \#

Laboratory Name

SC Laboratory Certification \#

Subcontracted Laboratory Certification \#

Subcontracted Laboratory Name

Laboratory Receipt Information (Chain of Custody Must be Attached)

\begin{tabular}{c} 
Semi-Volatile Organic Compounds \\
\hline Selo
\end{tabular}

Results in Milligrams per Liter

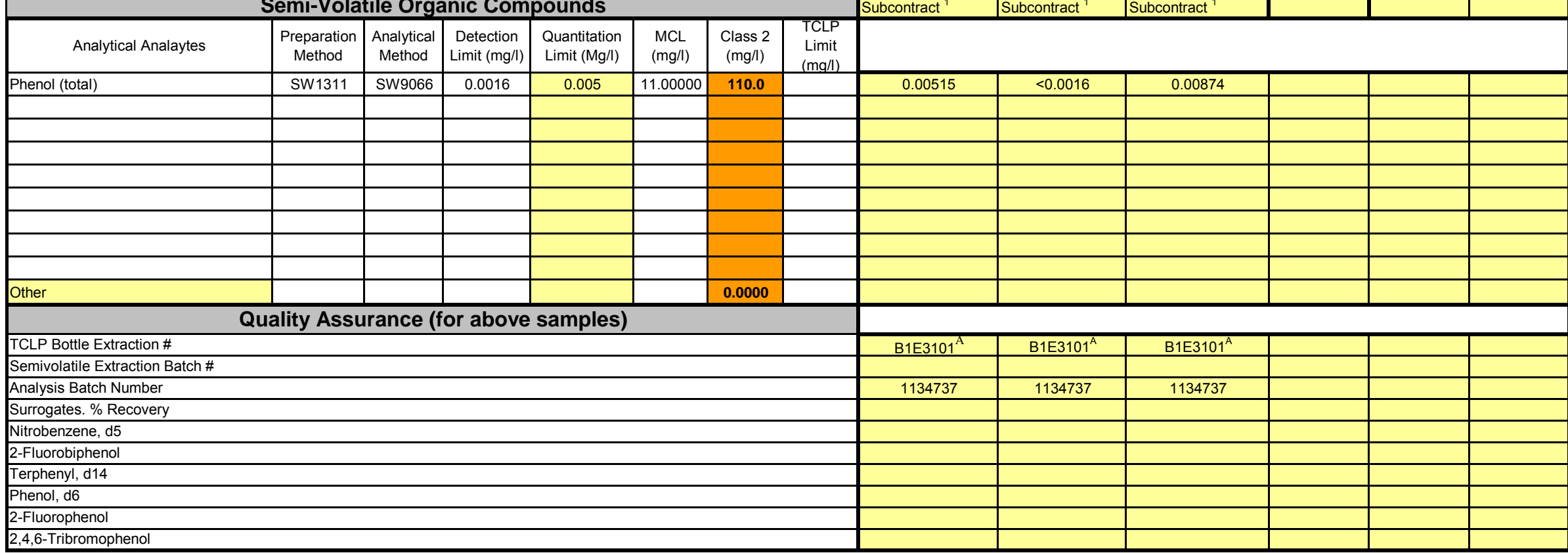

1. Subcontracted Laboratory used for this Analyte.

A. TCLP Extract for Phenols performed by B\&W Technical Services Group - RACL as TCLP Batch\# B1E3101 and shipped to subcontractor GEL Laboratories

$Z$ DOECAP, NUPIC and NELAP requirements 


\section{H E G

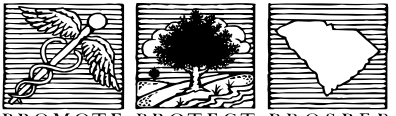

PROMOTE PROTECT PROSPER

South Carolina Department of Healt and Environmental Control

\section{西}

Instrument:

Industrial RCRA - TCLP Volatiles \& Semivolatiles

Lachat QuickChem FIA+ 8000

\begin{tabular}{|c|c|c|c|c|c|c|c|c|c|c|c|c|c|c|c|c|c|}
\hline \multirow[b]{2}{*}{ Analytes } & \multicolumn{8}{|c|}{ Analyte Concentrations, $\mathrm{Mg} / \mathrm{I}$} & \multicolumn{8}{|c|}{ Recovery Percent } & \multirow[t]{2}{*}{ Flags } \\
\hline & RDL & MDL & Blank & LCS & LCSD & MS & MSD & Other & LCS & LCSD & MS & MSD & Ave MS/MSD & REC Limits & $\%$ RPD & RPD Limits & \\
\hline Benzene & 0.01 & 0.003 & $<0.003$ & 0.0441 & - & 0.055 & 0.0527 & & 88.1 & - & 110 & 105 & 108 & $75-118$ & 4.22 & $0-20$ & \\
\hline Toluene & 0.01 & 0.0025 & $<0.0025$ & - & - & - & - & & - & - & - & - & - & - & - & - & \\
\hline n-Butanol & 0.5 & 0.15 & $<0.15$ & - & - & - & - & & - & - & - & - & - & - & - & - & \\
\hline Toluene-d8 & - & - & - & 0.049 & - & 0.0479 & 0.0473 & & 97.9 & - & 95.9 & 94.6 & 95.3 & $80-120$ & - & - & \\
\hline 1,2-Dichloroethane-d4 & - & - & - & 0.051 .8 & - & 0.049 & 0.0478 & & 104 & - & 98 & 95.7 & 97 & $79-124$ & - & - & \\
\hline Bromofluorbenzene & - & - & - & 0.0495 & - & 0.0487 & 0.0473 & & 99 & - & 97.4 & 94.6 & 96 & $80-120$ & - & - & \\
\hline Phenol & 0.005 & 0.0016 & 0.012 & 0.0517 & 0.049 & - & - & & 103 & 98 & - & - & - & - & 5.36 & $0-20$ & \\
\hline & & & & & & & & & & & & & & & & & \\
\hline & & & & & & & & & & & & & & & & & \\
\hline & & & & & & & & & & & & & & & & & \\
\hline & & & & & & & & & & & & & & & & & \\
\hline & & & & & & & & & & & & & & & & & \\
\hline Clock ID & & & & & & & & & & & & & & & & & \\
\hline & & & & & & & & & & & & & & & & & \\
\hline & & & & & & & & & & & & & & & & & \\
\hline & & & & & & & & & & & & & & & & & \\
\hline & & & & & & & & & & & & & & & & & \\
\hline
\end{tabular}

Footnotes:

LABORATORY: GEL Laboratories LLC

METHOD NAME: SW846-8260B and SW846-9066 QC Report

SUBJECT: $\quad$ QA- Blk, Laboratory Control Sample (LCS), Matrix Spike (MS), Matrix Spike Duplicate (MSD)

rogate Results for LCS, MD, MD and recoveries are listed above 


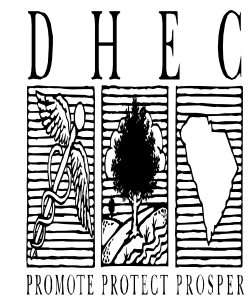

SouhC Carolina Department of Health and Enirionmentala Control

\section{Cross Reference Report for QA and Analytes}

Analytical Method Reference: Lab Reference (to Facility Sample):

Subject / Project:

Facility:

SW846-1311/8260B(VOC) \& SW846-9066 Phenol

\begin{tabular}{|c|c|c|c|c|c|c|}
\hline LAB ID \# & FACILITY SAMP ID \# & TC EXTR BATCH \# & DIGESTION BATCH \# & ANALYSIS BATCH \# & OTHER & COMMENTS \\
\hline 1202469481 TCLP Blk & None & 1134218 & Not Applicable & 1135656 & - & 8260B VOC \\
\hline 1202472889 LCS & None & 1134218 & Not Applicable & 1135656 & - & 8260B VOC \\
\hline 1202472887 MS & 11114-SS-VAULT1 & 1134218 & Not Applicable & 1135656 & - & 8260B VOC \\
\hline 1202472888 MSD & 11114-SS-VAULT1 & 1134218 & Not Applicable & 1135656 & - & 8260B VOC \\
\hline 284341001 & 11114-SS-VAULT1 & 1134218 & Not Applicable & 1135656 & - & 8260B VOC \\
\hline 284341002 & 11114-SS-VAULT2 & 1134218 & Not Applicable & 1135656 & - & 8260B VOC \\
\hline 284341003 & 11114-SS-VAULT3 & 1134218 & Not Applicable & 1135656 & - & 8260B VOC \\
\hline 284341007 TCLP BLK & None & $\mathrm{B} 1 \mathrm{E} 3101^{\mathrm{A}}$ & 1134736 & 1134737 & - & 9066 Phenols Total \\
\hline 1202470772 Meth Blk & None & None & 1134736 & 1134737 & - & 9066 Phenols Total \\
\hline 1202470773 LCS & None & None & 1134736 & 1134737 & - & 9066 Phenols Total \\
\hline 1202470774 LCSD & None & None & 1134736 & 1134737 & - & 9066 Phenols Total \\
\hline 284341004 & 11114-SS-VAULT1 & $\mathrm{B} 1 \mathrm{E} 3101^{\mathrm{A}}$ & 1134736 & 1134737 & - & 9066 Phenols Total \\
\hline 284341005 & 11114-SS-VAULT2 & $\mathrm{B} 1 \mathrm{E} 3101^{\mathrm{A}}$ & 1134736 & 1134737 & - & 9066 Phenols Total \\
\hline 284341006 & 11114-SS-VAULT3 & ${\mathrm{B} 1 \mathrm{E} 3101^{\mathrm{A}}}$ & 1134736 & 1134737 & - & 9066 Phenols Total \\
\hline & & & & & & \\
\hline & & & & & & \\
\hline & & & & & & \\
\hline
\end{tabular}

Footnotes

A. TCLP Extract for Phenols performed by B\&W Technical Services Group - RACL as TCLP Batch\# B1E3101 and shipped to subcontractor GEL Laboratories 


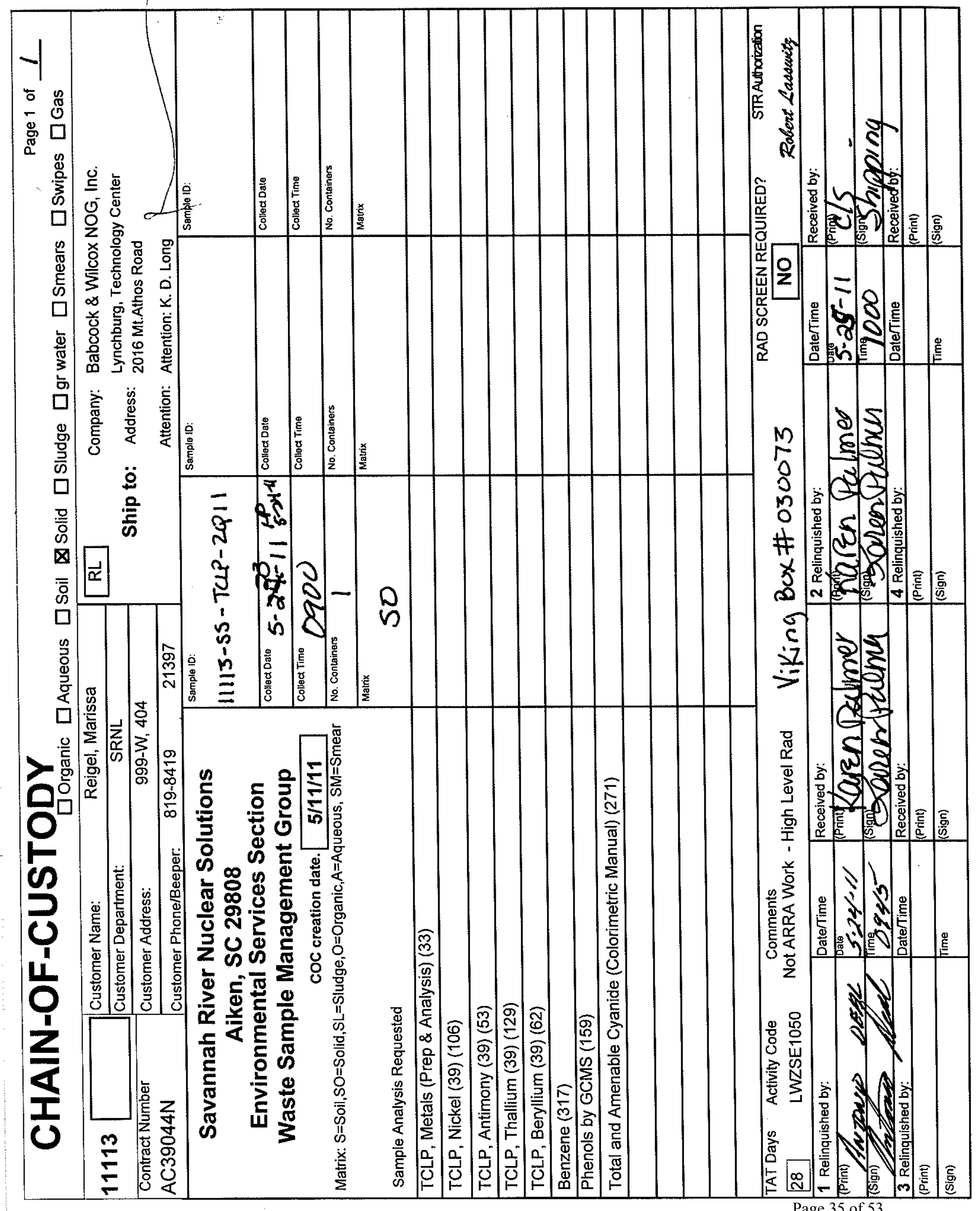




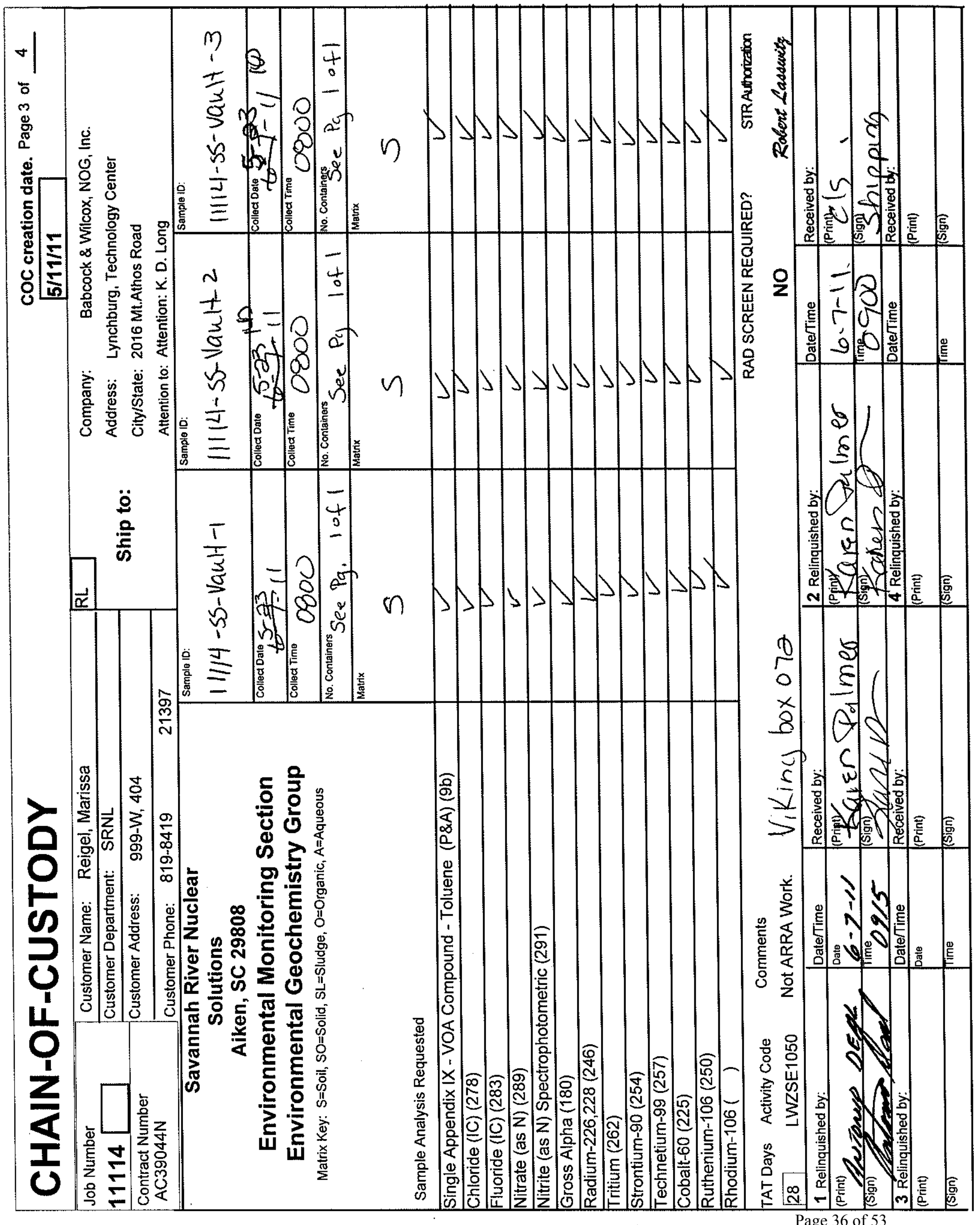




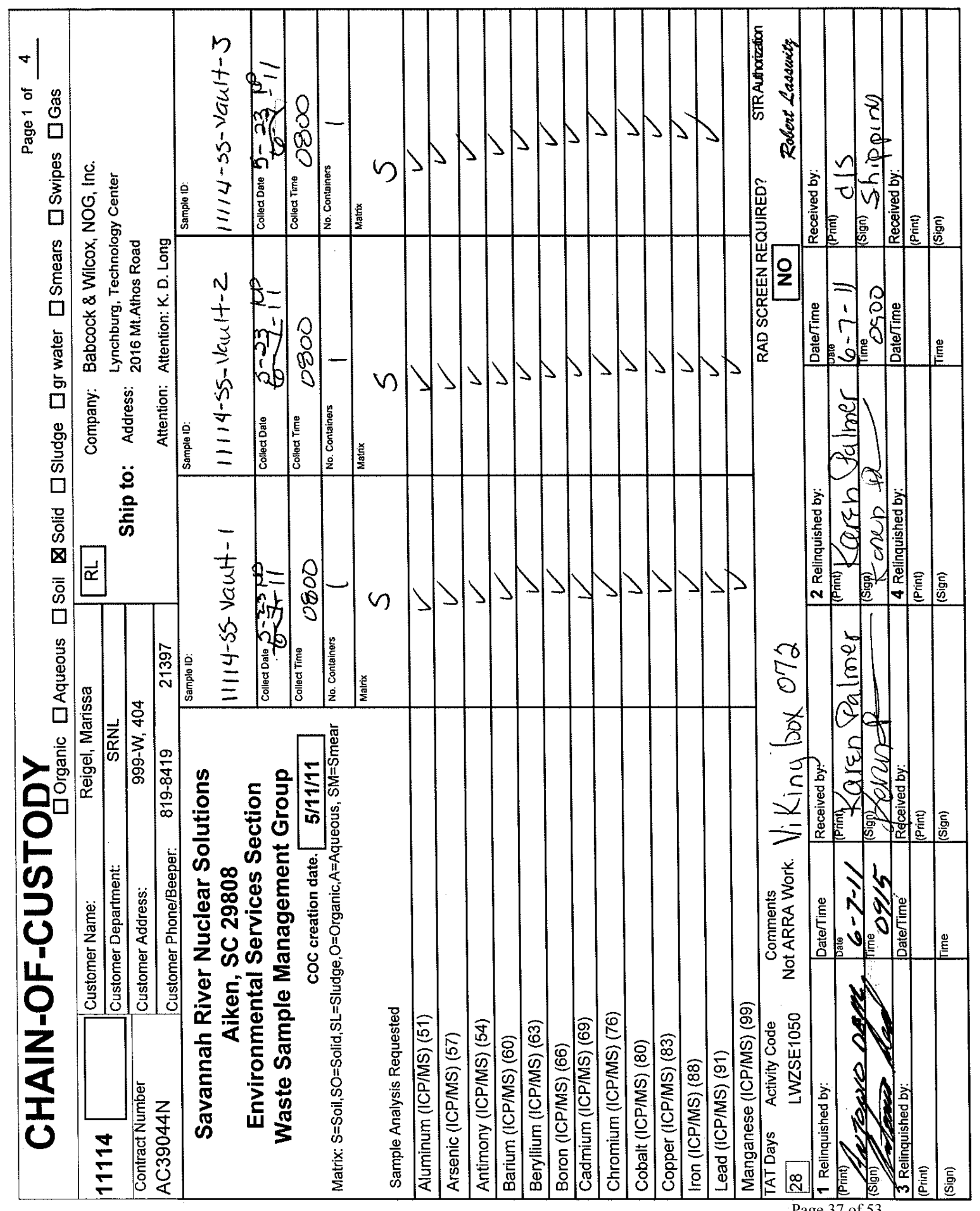




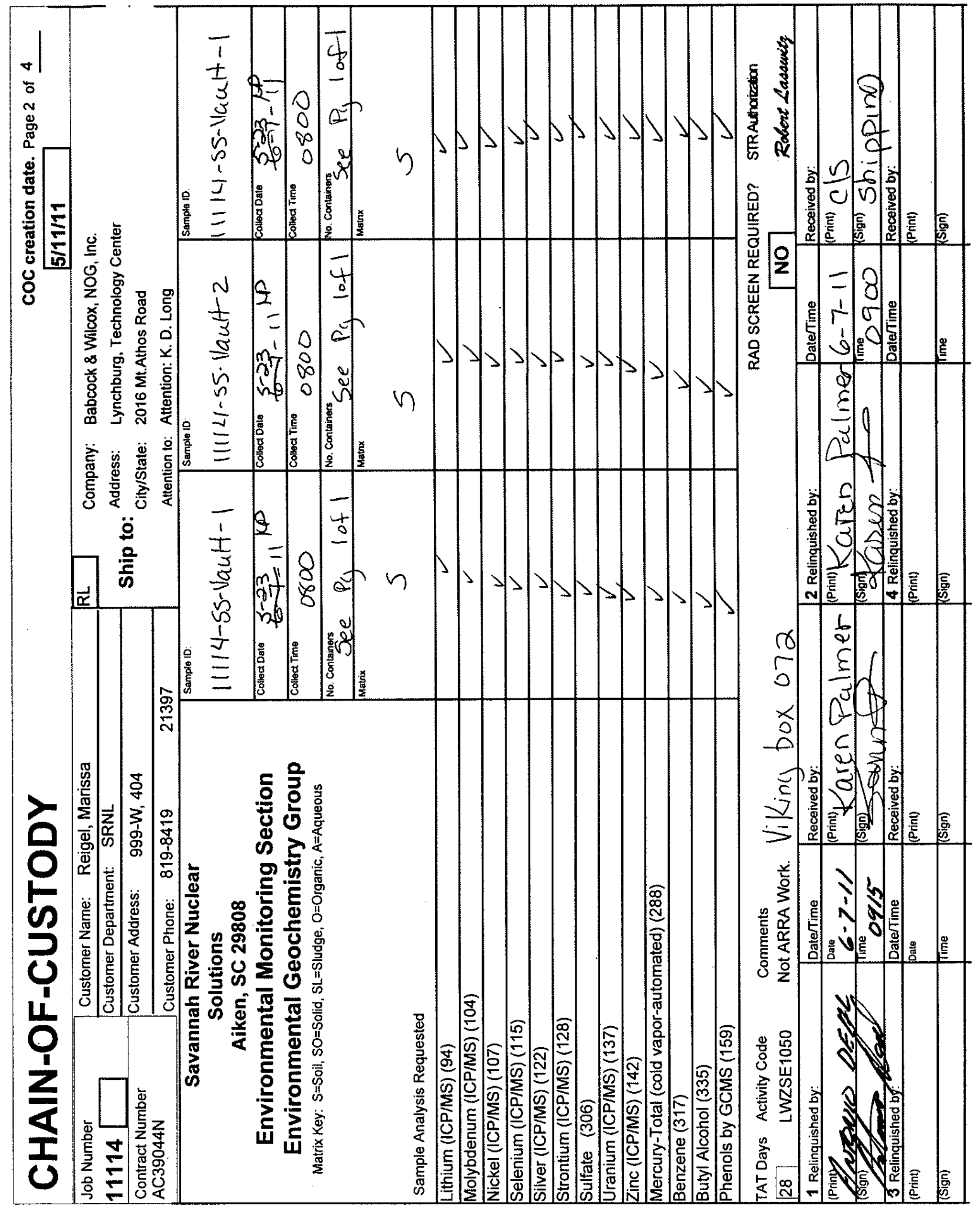




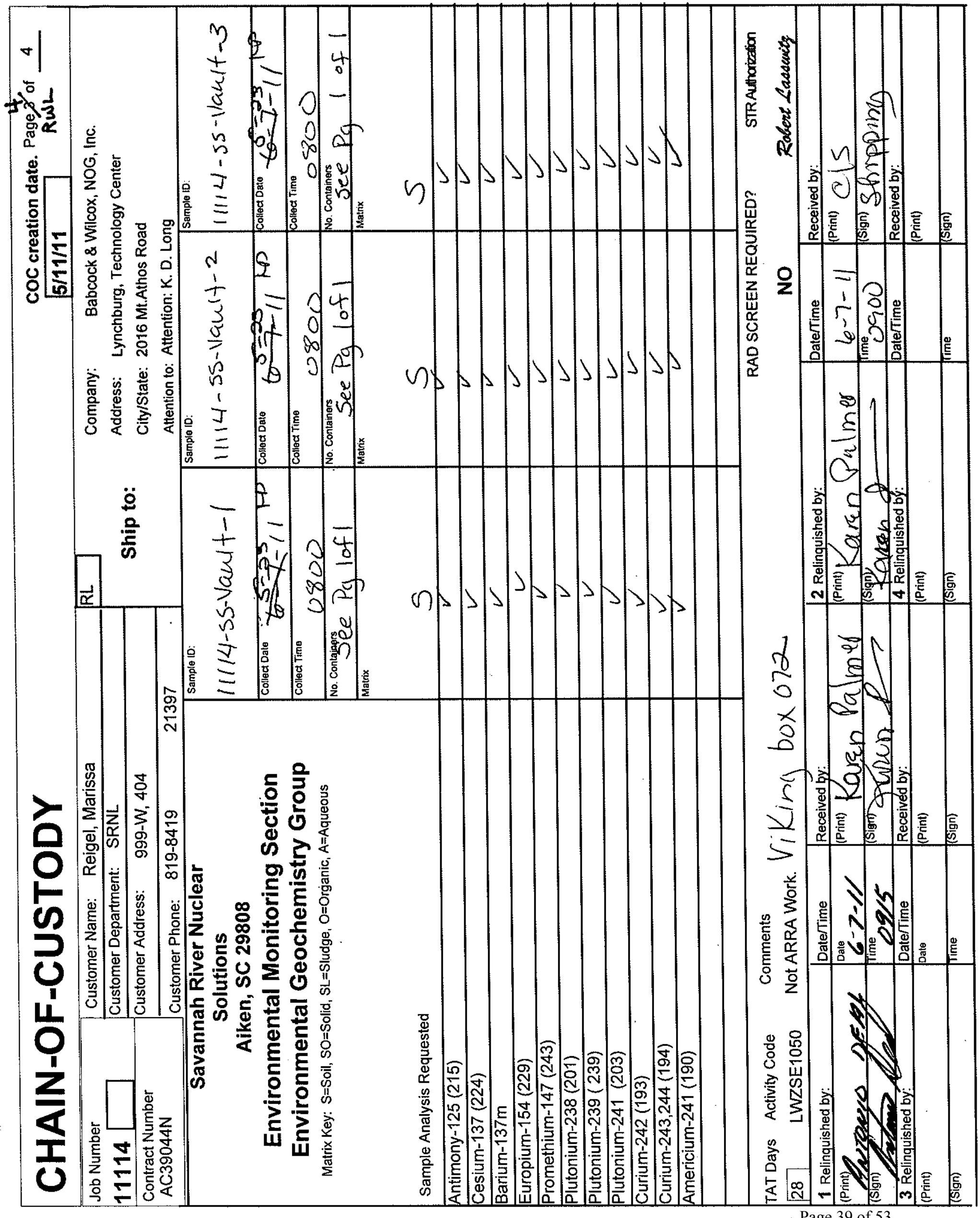




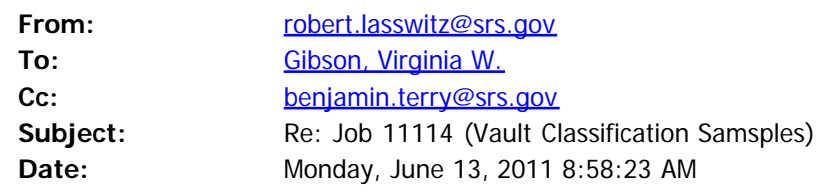

Virginia,

Please proceed with the analysis.

Thanks,

Bob Lasswitz

SRNS

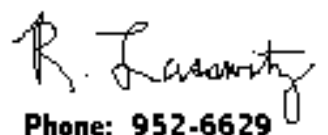

Page: 14903

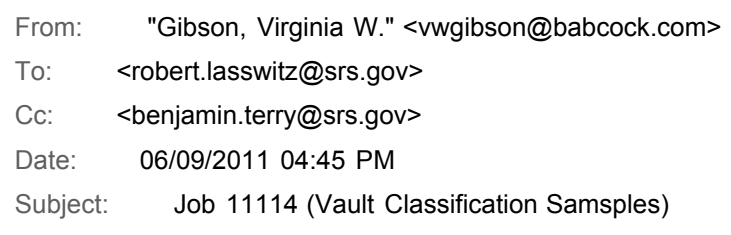

Bob,

We received the vault classification samples (Job 11114) this afternoon.

Upon receipt, the container temperature was outside the required range $4 \pm 2^{0} \mathrm{c}$ ( measured at $15^{\circ} \mathrm{c}$ ). The samples have also exceeded the 14 day hold time limit for the organic compounds (Sampled 5/23/11). Please let me know how you would like to proceed.

Best Regards, Virginia

Virginia W. Gibson

Babcock\& Wilcox Technical Services Group, Inc.

2016 Mt. Athos Road

Lynchburg, VA 24504-5447

(434) 522-6546

(434) 522-6860 (Fax)

vwgibson@babcock.com

This message is intended only for the individual or entity to which it is addressed and contains information that is proprietary to The Babcock \& Wilcox Company and/or its affiliates, or may be otherwise confidential. If the reader of this message is not the intended recipient, or the employee agent responsible for delivering the message to the intended recipient, you are hereby notified that any dissemination, distribution or 
copying of this communication is strictly prohibited. If you have received this communication in error, please notify the sender immediately by return e-mail and delete this message from your computer. Thank you.

This message is intended only for the individual or entity to which it is addressed and contains information that is proprietary to The Babcock \& Wilcox Company and/ or its affiliates, or may be otherwise confidential. If the reader of this message is not the intended recipient, or the employee agent responsible for delivering the message to the intended recipient, you are hereby notified that any dissemination, distribution or copying of this communication is strictly prohibited. If you have received this communication in error, please notify the sender immediately by return email and delete this message from your computer. Thank you. 


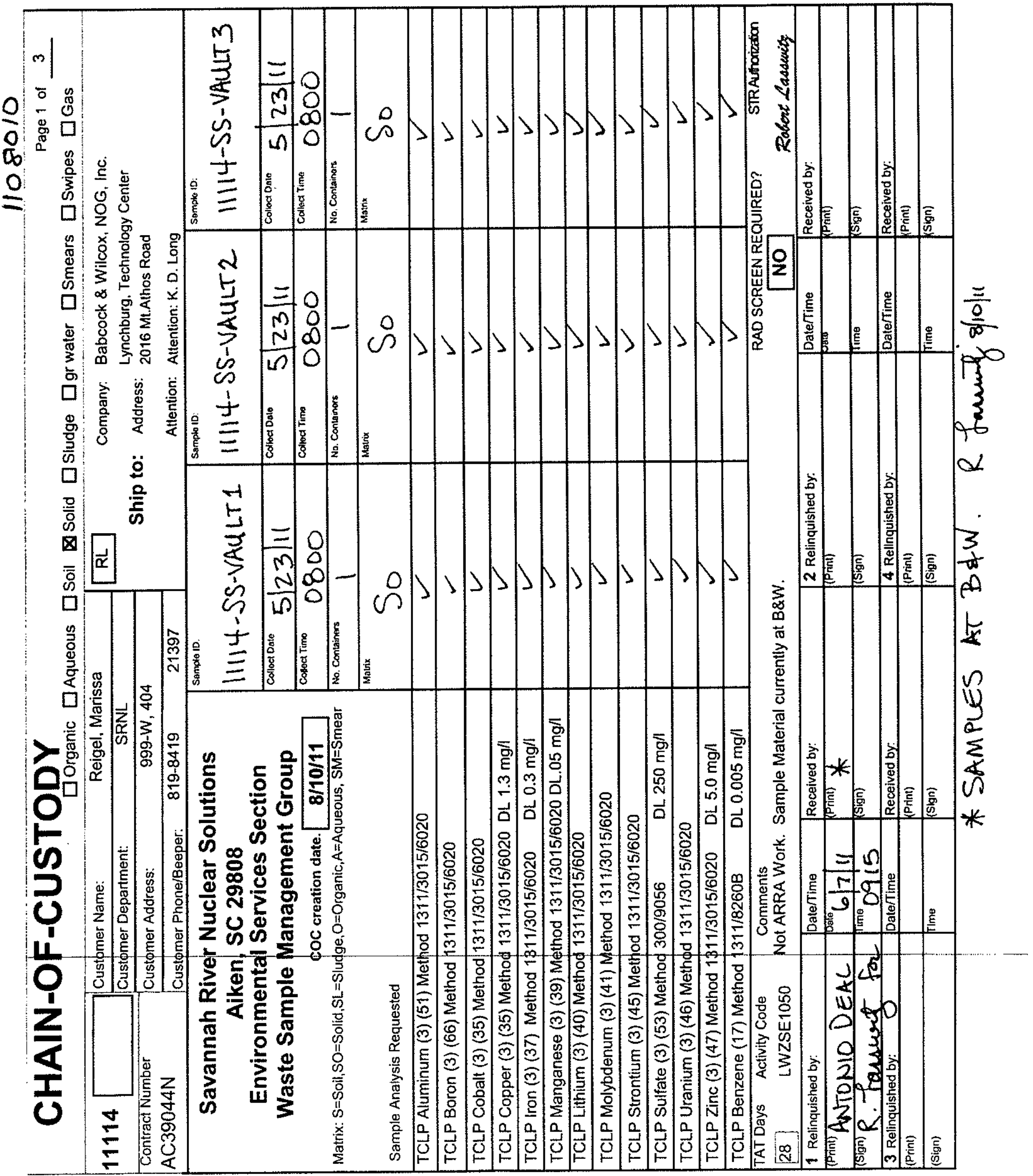




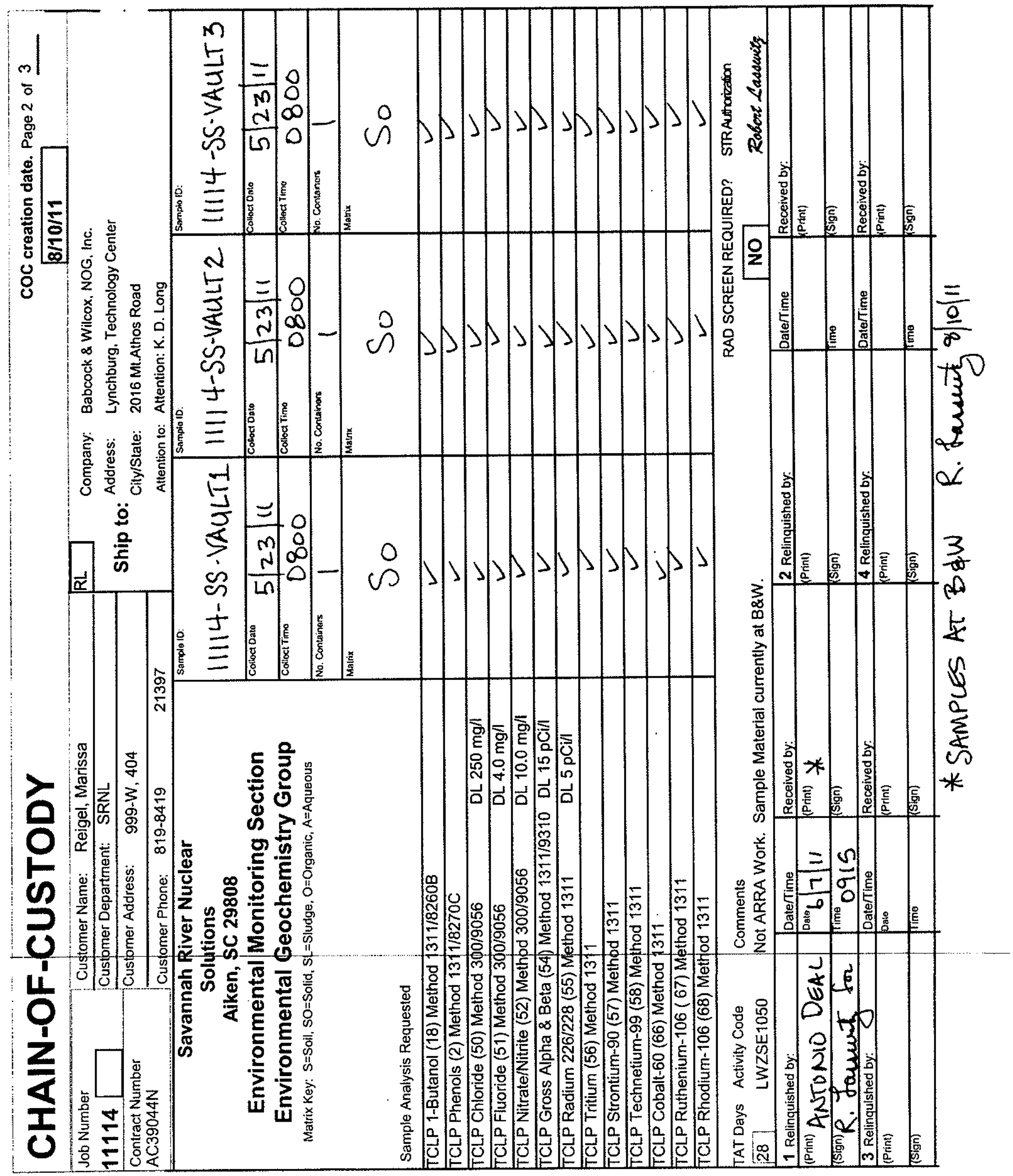




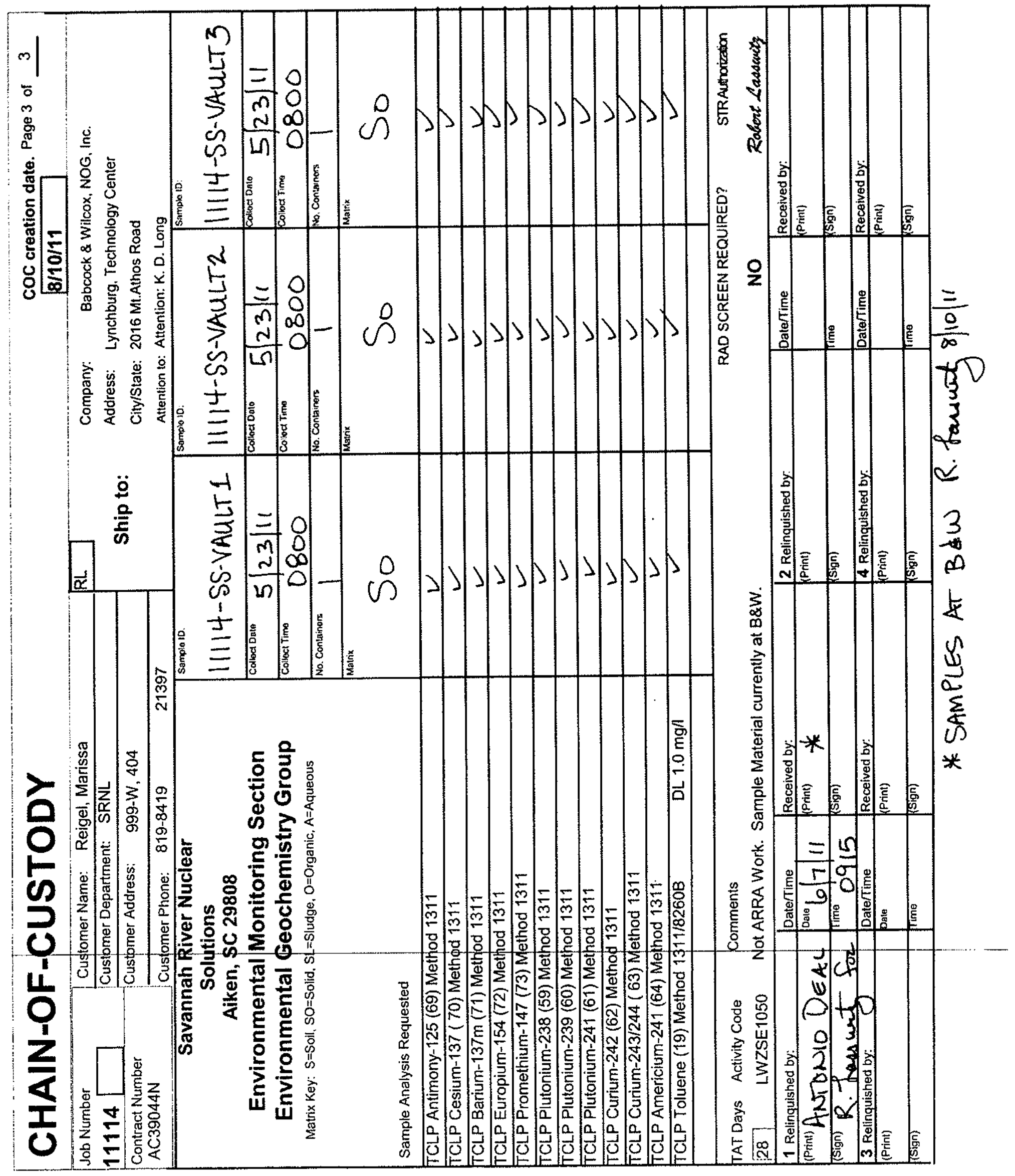


Willis, Ken W.

$\begin{array}{ll}\text { From: } & \text { robert.lasswitz@srs.gov } \\ \text { Sent: } & \text { Thursday, August 11, 2011 7:33 AM } \\ \text { To: } & \text { Gibson, Virginia W.; Willis, Ken W. } \\ \text { Cc: } & \text { benjamin.tery@srs.gov; lori.coward@srs.gov; Marissa.Reigel@srnl.doe.gov; } \\ & \text { allan.barnes@srnl.doe.gov } \\ \text { Subject: } & \text { Job 11114-COC's } \\ \text { Attachments: } & \text { DOC.PDF }\end{array}$

Virginia,

The three (3) pages of COC's I sent you yesterday were not filled out - just blanks. Attached are ones that are.

Bob

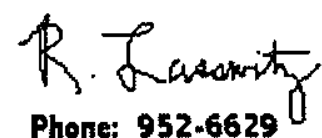

Page: 14903 
Gibson, Virginia W.

From:

Sent:

To:

Cc:

Subject:
Gibson, Virginia W.

Wednesday, August 10, 2011 3:21 PM

'robert.lasswitz@srs.gov'

benjamin.terry@srs.gov; lori.coward@srs.gov; Marissa.Reigel@srnl.doe.gov; allan.barnes@srnl.doe.gov; Willis, Ken W.

RE: Job 11114 - COC's for TCLP analysis

Bob,

Based on the provided COC information, we will begin analysis of vault classification samples 11114-SS-VAULT1, 11114SS-VAULT2 and 11114-SS-VAULT3 for the requested analyses. These samples were originally logged under the delivery group (SDG) identification number 1106010. Since a report and invoice have already been issued for the work performed under the 1106010 SDG number, the samples will be reclogged under a new delivery group number.

The work will be performed on a 14 D TAT beginning today. Per conversation with Marissa Reigel, the reporting format for this work will be a typical level IV report with no EDD required.

Please let me know if any of the above information is incorrect.

Best Regards,

Virginia

From: robert.lasswitz@srs.gov [mailto:robert.lasswitz@srs.gov]

Sent: Wednesday, August 10, 2011 2:19 PM

To: Gibson, Virginia W.; Willis, Ken W.

Cc: benjamin.terry@srs.gov; lori.coward@srs.gov; Marissa.Reigel@srnl.doe.gov; allan.barnes@srnl.doe.gov

Subject: Job 11114 - COC's for TCLP analysis

Virginia,

Attached are the three pages of the COC for our TCLP request on Job 11114. Please let me know if you have any questions.

Thanks,

Bob

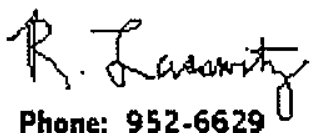

Phone: 952-6629

Page: 14903 


\section{Chain of Custody and Supporting Documentation}




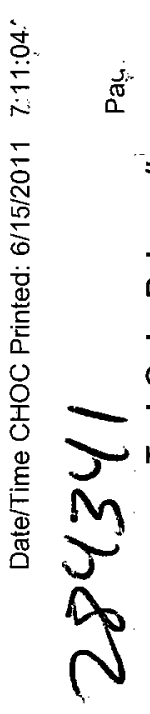

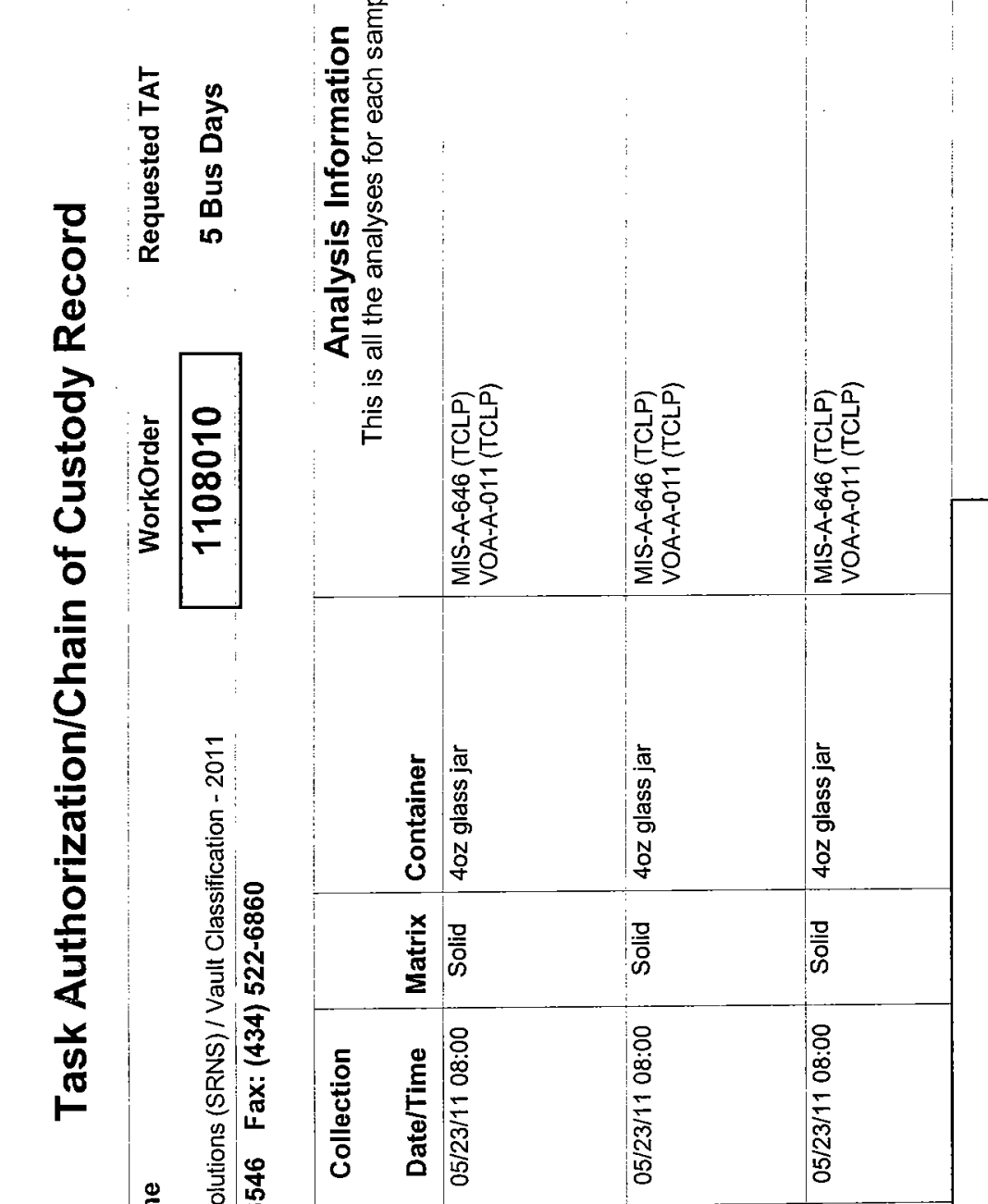

P
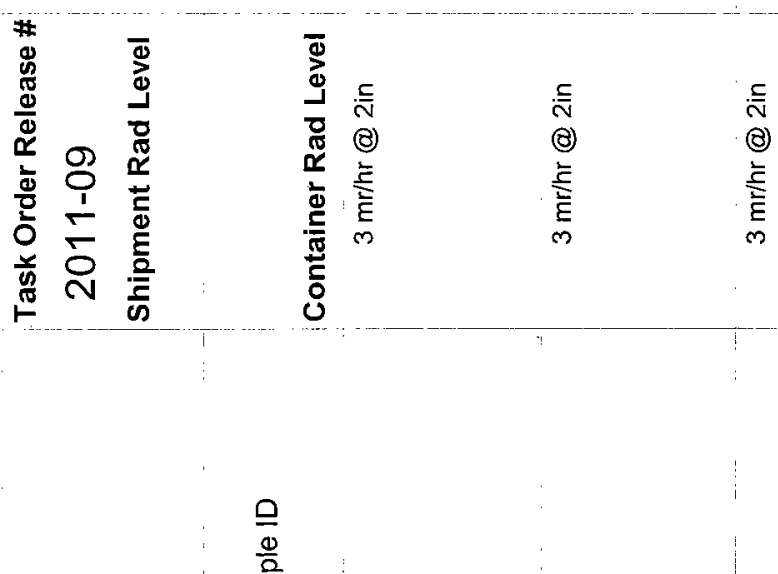

으 음

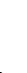




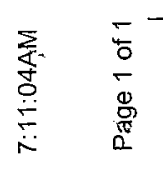

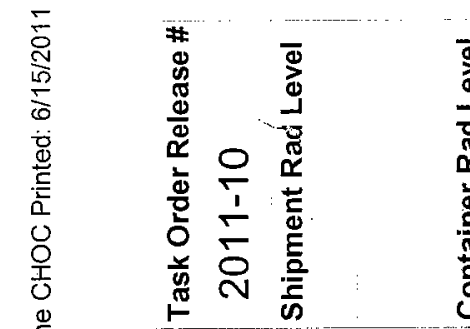

$\stackrel{\mathbb{E}}{\underline{E}}$

$\stackrel{\Phi}{\square}$

N

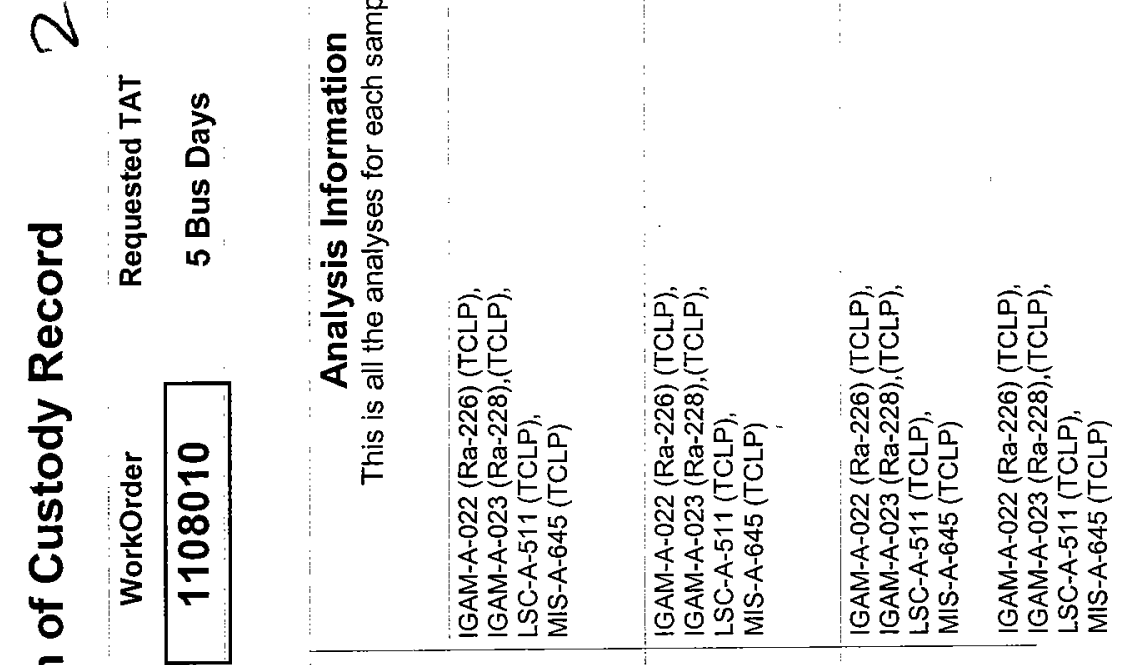

5

$\frac{5}{5}$

등

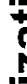

Nㅜㄴ

$\frac{2}{\frac{1}{3}}$

$x$ 늘

$\frac{n}{n}$

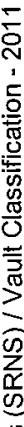

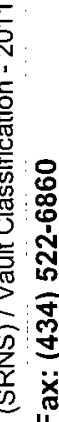

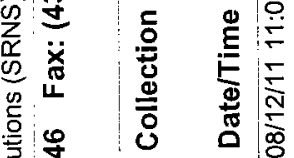

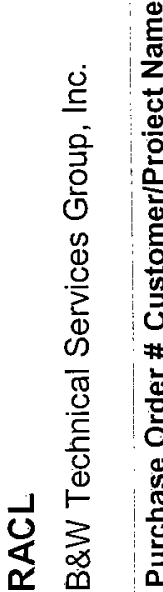

品突

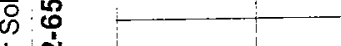

ฐ స

紊

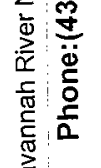

i

空

总

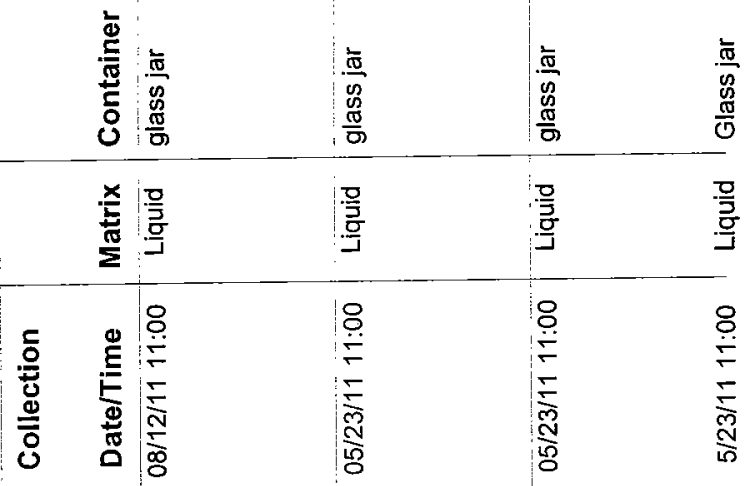

Page 6 of 280

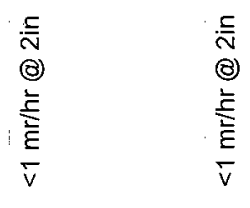

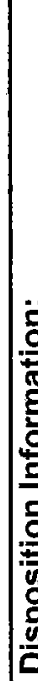

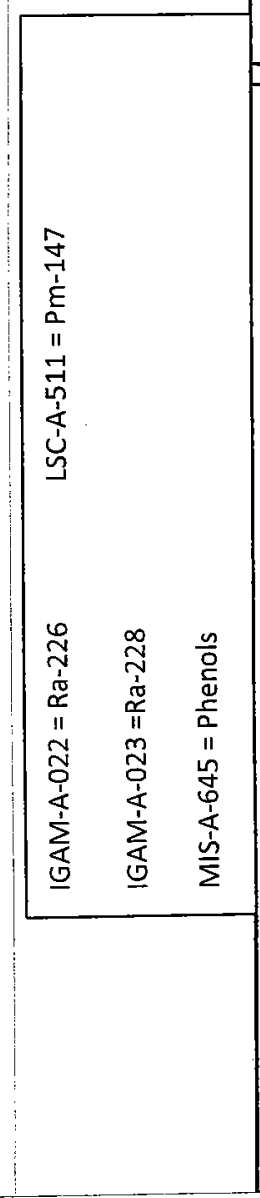

SRNL-\$TI-2011-00561

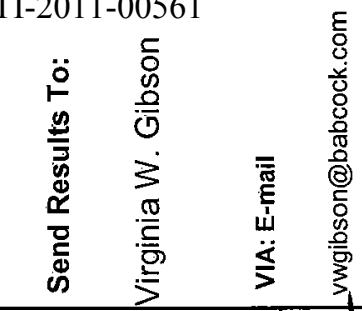

$\stackrel{\frac{1}{d}}{\frac{d}{2}}$

$\sum_{0}^{\infty} \square$

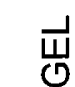

(8)

을

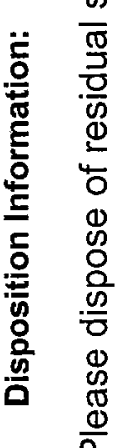

$\overline{\bar{\Phi}} \square$

产

$\frac{N}{0} \square$

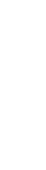

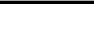

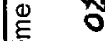

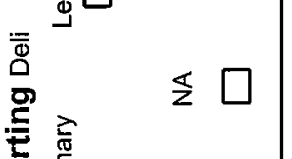

部

ธ

马

这

亭

舟

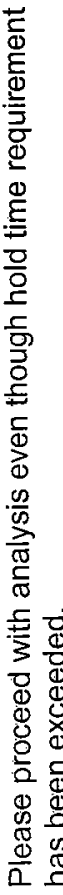

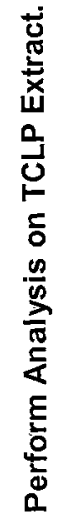




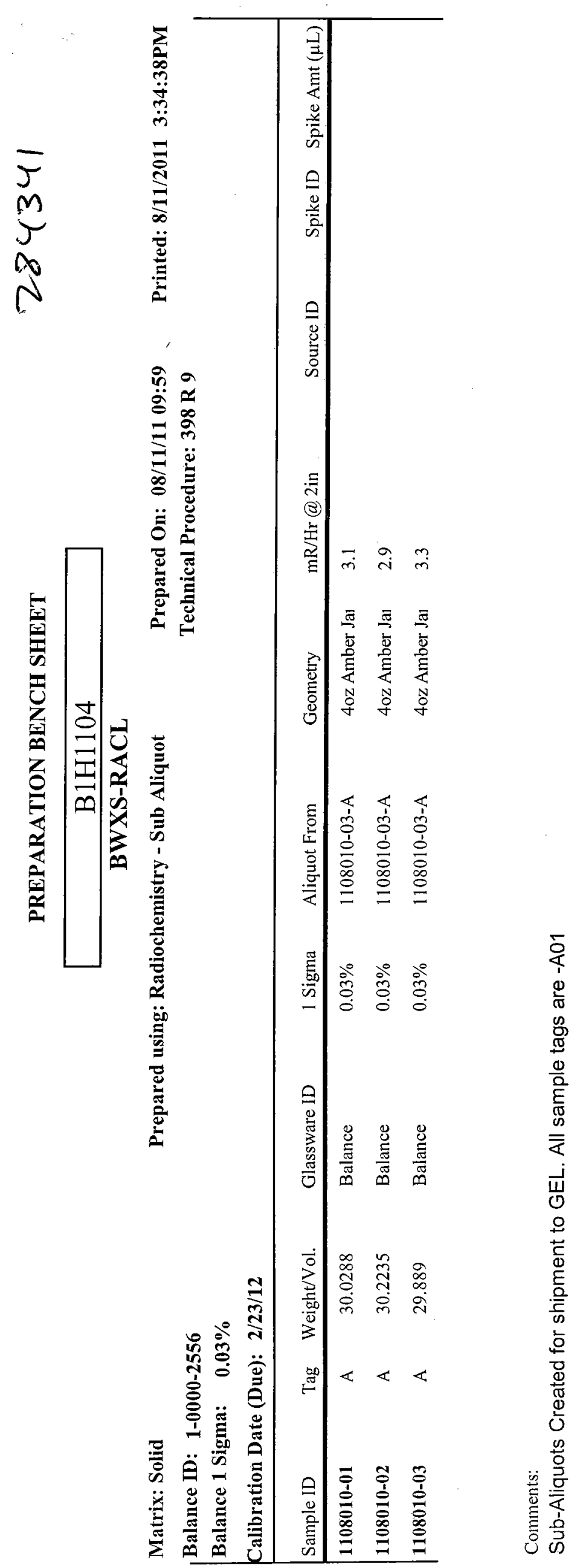




\begin{tabular}{|c|c|c|c|}
\hline Buxt & & & SDG/AR/COC/Work Order: 284341 \\
\hline Received By: & & & Date Received: $8-18-11$ \\
\hline Suspected Hazard Information & & $\dot{z}$ & $\begin{array}{l}\text { *If Counts }>\times 2 \text { area background on samples not marked "radioactive", contact the Radiation Safety Group for } \\
\text { further investigation. }\end{array}$ \\
\hline COC/Samples marked as radioactive? & $\checkmark$ & 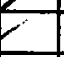 & Maximum Counts Observed*: \\
\hline Classified Radioactive II or III by RSO? & 7 & & $\angle L O n, D=1.5$ \\
\hline COC/Samples marked containing PCBs? & & $\checkmark$ & \\
\hline Shipped as a DOT Hazardous? & $\checkmark$ & & Hazard Class Shipped: 7 \\
\hline Samples identified as Foreign Soil? & & $\not$ & \\
\hline
\end{tabular}

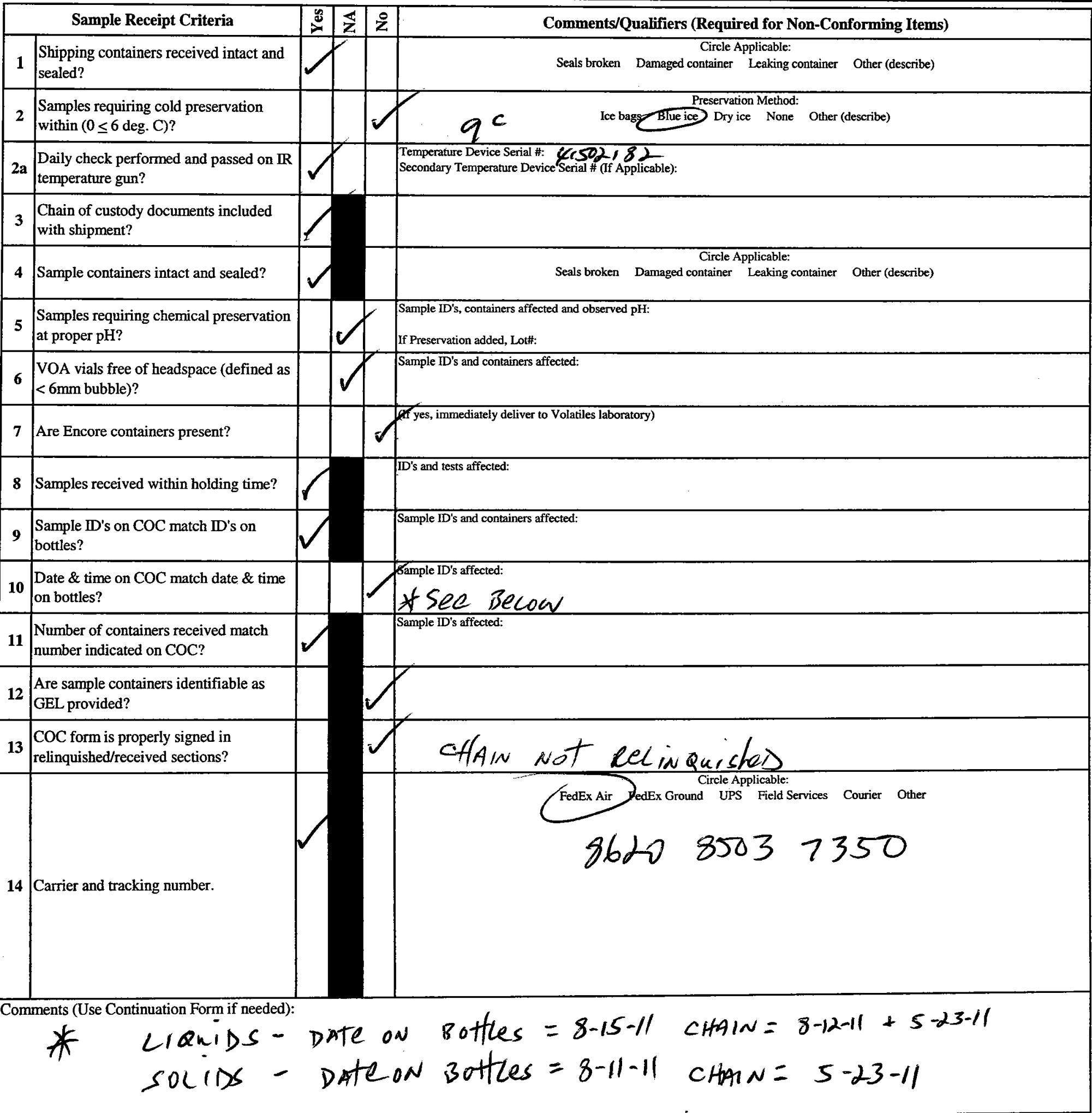

PM (or PMA) review: Initials RA Date $8 / 18 / 11$ Page 1 of 1


Subject: RE: TCLP samples received at GEL last week

From: "Gibson, Virginia W." <vwgibson @babcock.com>

Date: Tue, 23 Aug 2011 16:12:34 -0400

To: "Ricky Albee" <richard.albee@gel.com>

CC: "team.albee" <team.albee@gel.com>

Ricky，

Please proceed with the analyses.

The liquid sample dates should be 8/12/11 a 11:00. This is the time of TCLP extract collection.

The solid sample dates should be 5/23/11. This is the time of sample collection by the customer.

Please let me know if you have additional questions.

Best regards,

Virginia

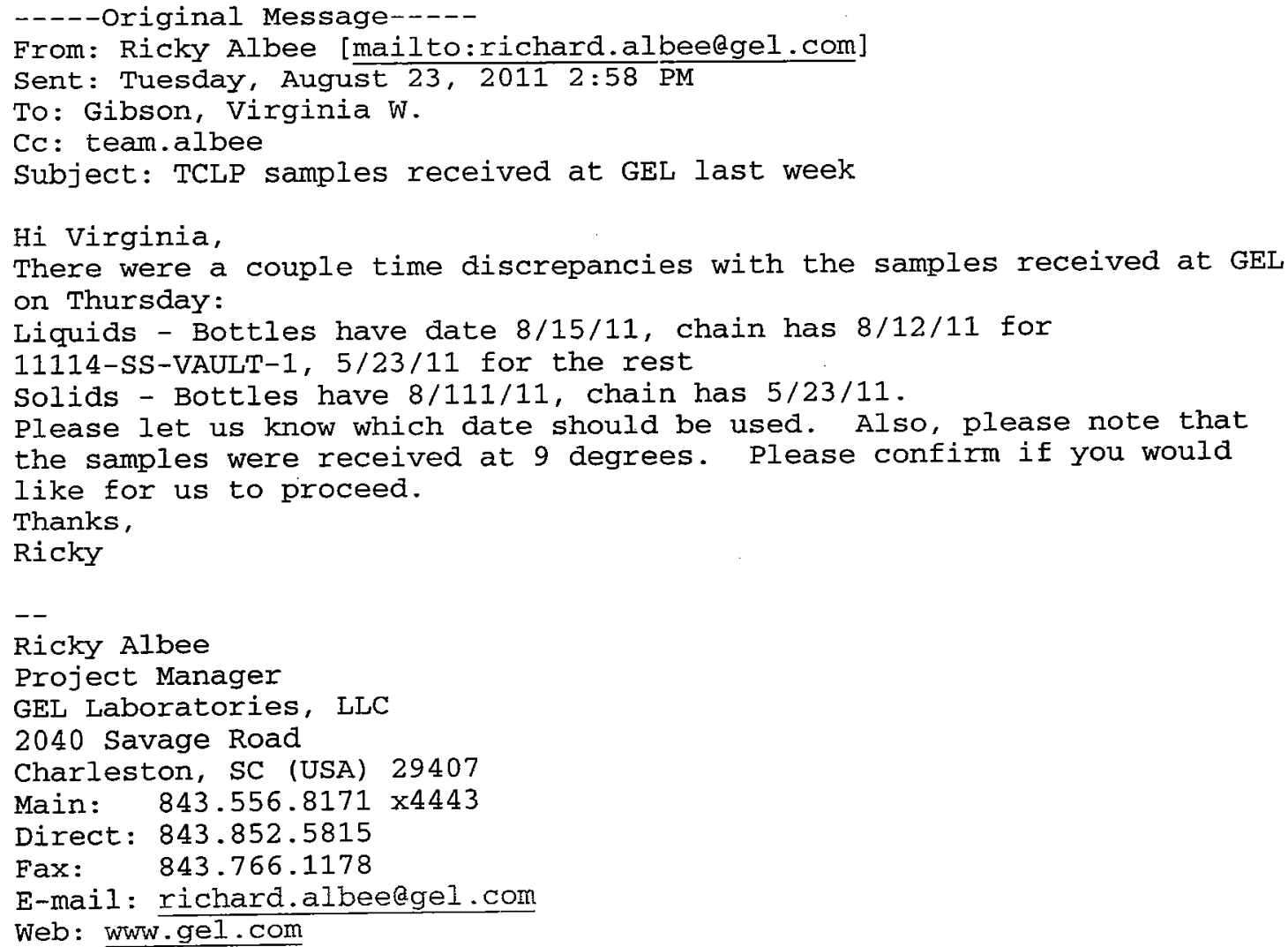

CONFIDENTIALITY NOTICE: This e-mail and any files transmitted with it are the property of The GEL Group, Inc. and its affiliates. All rights, including without limitation copyright, are reserved. The proprietary information contained in this e-mail message, and any files transmitted with it, is intended for the use of the recipient(s) named above. If the reader of this e-mail is not the intended recipient, you are hereby notified that you have received this e-mail in error and that any review, distribution or copying of this e-mail or any files 
transmitted with it is strictly prohibited. If you have received this e-mail in error, please notify the sender immediately and delete the original message and any files transmitted. The unauthorized use of this e-mail or any files transmitted with it is prohibited and disclaimed by The GEL Group, Inc. and its affiliates.

This message is intended only for the individual or entity to which it is addressed and contains information that is proprietary to The Babcock \& Wilcox Company and/or its affiliates; or may be otherwise confidential. If the reader of this message is not the intended recipient, or the employee agent responsible for delivering the message to the intended recipient, you are hereby notified that any dissemination, distribution or copying of this communication is strictly prohibited. If you have received this communication in error, please notify the sender immediately by return e-mail and delete this message from your computer. Thank you. 


\section{Distribution:}

\begin{tabular}{|c|c|c|c|}
\hline Name: & Location: & Name: & Location: \\
\hline J.L. Adams & $704-14 Z$ & S.L. Marra & 773-A \\
\hline P.M. Almond & $773-43 A$ & D.J. Martin & $241-246 \mathrm{H}$ \\
\hline A.B. Barnes & 999-W & P.W. Norris & $704-Z$ \\
\hline P.L. Bovan & $704-27 \mathrm{~S}$ & A.B. Osteen & $704-Z$ \\
\hline A.R. Carter & $704-14 Z$ & J.E. Occhipinti & 704-S \\
\hline N.F. Chapman & 766-H & E. Patten & $704-Z$ \\
\hline A.D. Cozzi & 999-W & F.M. Pennebaker & $773-42 A$ \\
\hline D.A. Crowley & 773-43A & J.W. Ray & $704-S$ \\
\hline C.E. Duffey & $704-61 \mathrm{H}$ & M.M. Reigel & 999-W \\
\hline A.D. England & $704-14 Z$ & L.B. Romanowski & 766-H \\
\hline S.D. Fink & 773-A & E.R. Seldon & $704-Z$ \\
\hline E.J. Freed & $704-56 \mathrm{H}$ & A.R. Shafer & $704-27 \mathrm{~S}$ \\
\hline B.J. Giddings & $786-5 A$ & D.C. Sherburne & 704-S \\
\hline J.C. Griffin & 773-A & F.M. Smith & $705-1 \mathrm{C}$ \\
\hline C.C. Herman & 999-W & A.V. Staub & $704-Z$ \\
\hline P.J. Hill & 766-H & B.C. Terry & 735-B \\
\hline C.A. Langton & 773-43A & A.W. Wiggins & 704-61H \\
\hline J.N. Leita & 704-30S & W.N. Wilson & $773-43 A$ \\
\hline K.R. Liner & $704-S$ & W.R. Wilmarth & 773-A \\
\hline M.J. Mahoney & 766-H & & \\
\hline & & & \\
\hline & & & \\
\hline
\end{tabular}

